\title{
Synthesis of CBD and Its Derivatives Bearing Various C4'-side Chains with a Late-Stage Diversification Method
}

Xudong Gong,,$\perp$ Changliang Sun, $₫$ Melkamu Alemu Abame, + Wenqiang Shi, Yuanchao Xie $\ddagger$, Wanbin $\mathrm{Xu},{ }^{\ddagger}$ Fuqiang Zhu, ${ }^{\S}$ Yan Zhang, ${ }^{\ddagger}$ Jingshan Shen, ${ }^{*} \ddagger$ and Haji A. Aisa*, ${ }^{\dagger}$

†The Key Laboratory of Plant Resources and Chemistry in Arid Regions and Key Laboratory of Xinjiang Indigenous Medicinal Plants Resource Utilization, Xinjiang Technical Institute of Physics and Chemistry, Chinese Academy of Sciences, South Beijing Road 40-1, Urumqi, Xinjiang 830011, People's Republic of China

${ }^{\perp}$ University of Chinese Academy of Sciences, No. 19A Yuquan Road, Beijing 100049, People's Republic of China.

§Topharman Shanghai Co., Ltd., Building 1, No. 388 Jialilue Road, Zhangjiang Hitech Park, Shanghai 201209, People's Republic of China

*AS Key Laboratory for Receptor Research, Shanghai Institute of Materia Medica, Chinese Academy of Sciences, 555 Zuchongzhi Road, Shanghai 201203, People's Republic of China

\section{Supporting Information}

Table of Contents

Section 1: NMR Spectroscopic Data............................................................ 2 
Section 1: NMR Spectroscopic Data

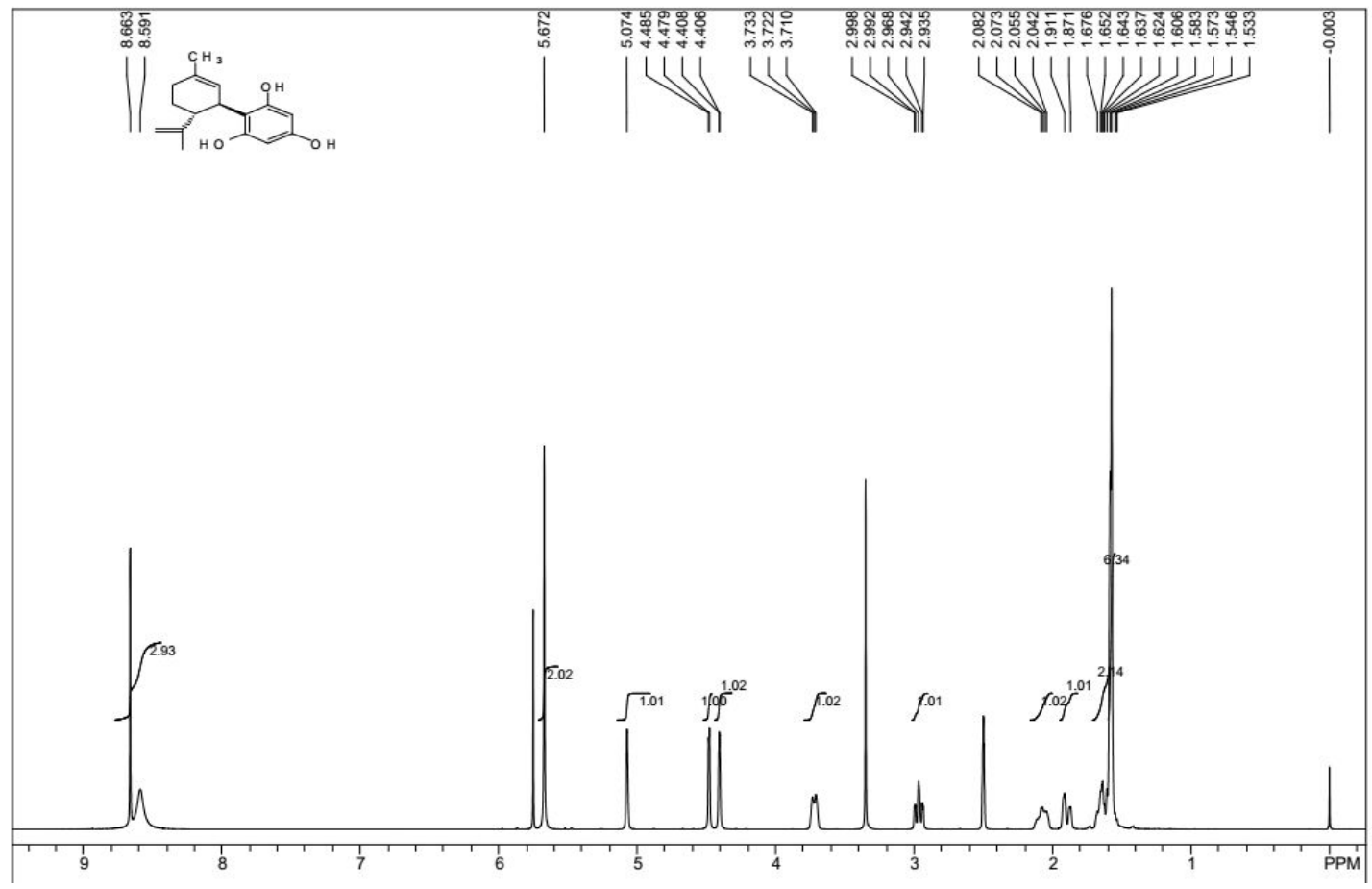

Figure S1 ${ }^{1} \mathrm{H}$ NMR(400 MHz) of $\mathbf{1}$ in DMSO- $d_{6}$

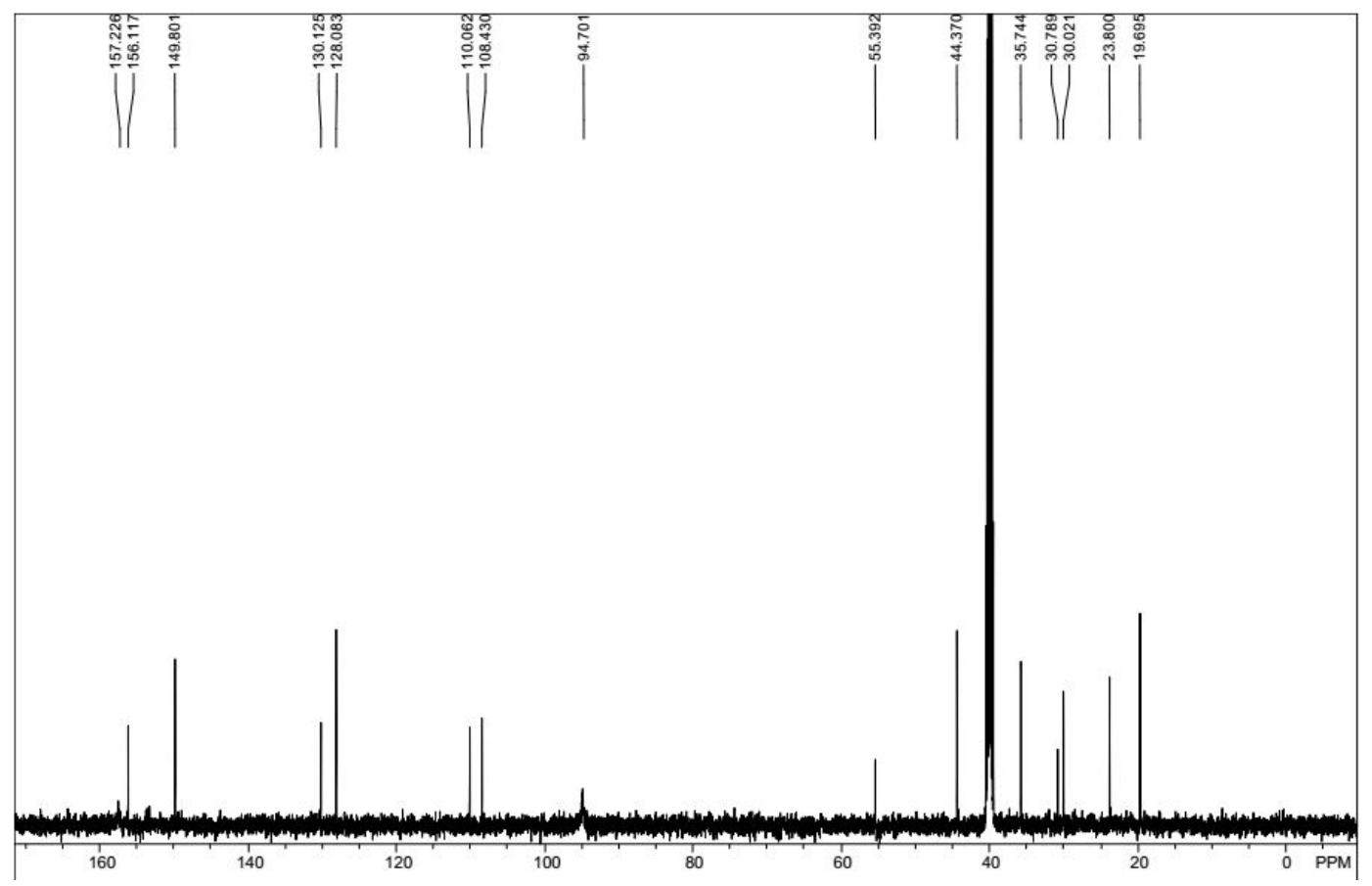

Figure S2 ${ }^{13} \mathrm{C}\left\{{ }^{1} \mathrm{H}\right\}$ NMR $(125 \mathrm{MHz})$ of $\mathbf{1}$ in DMSO- $d_{6}$ 


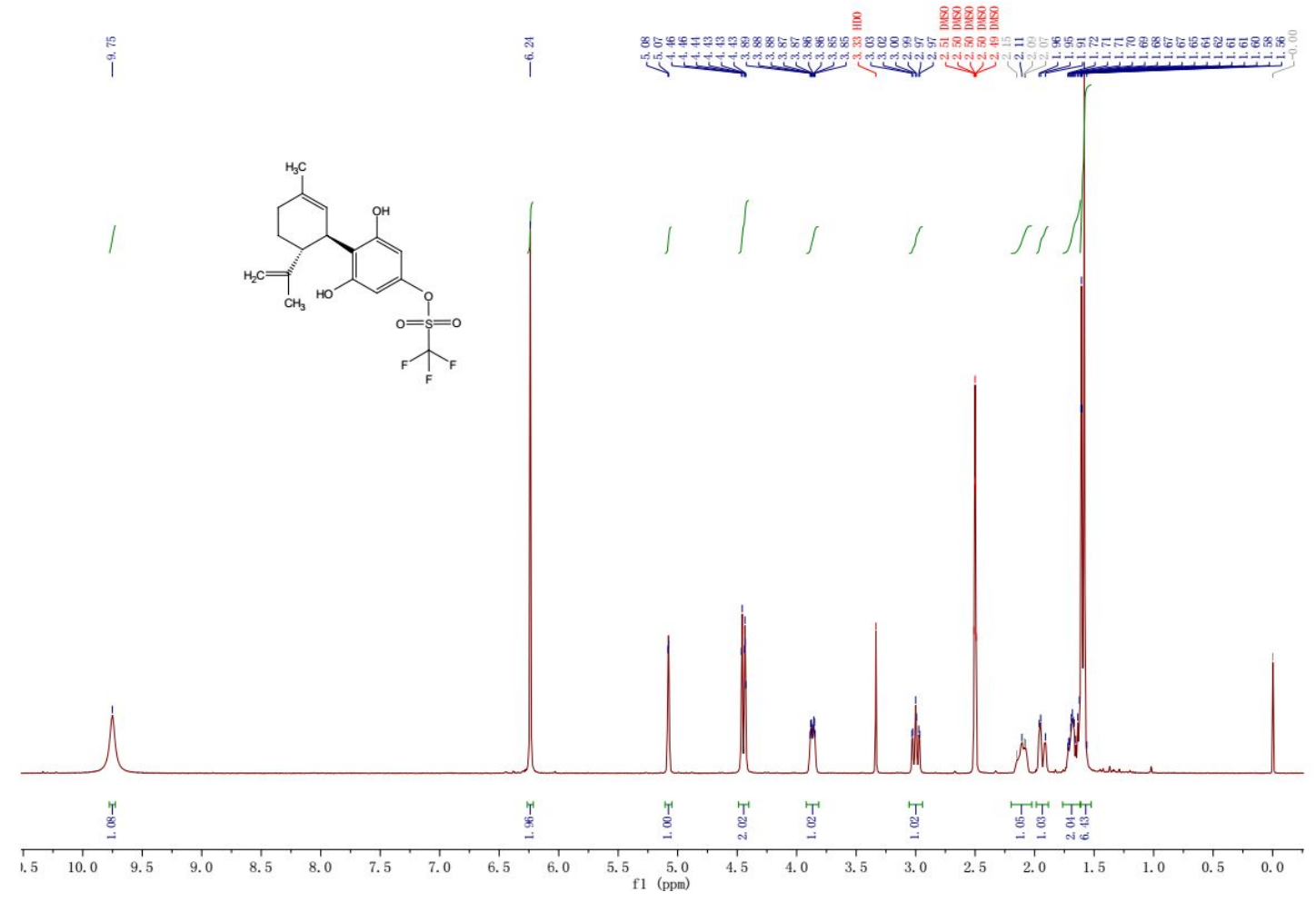

Figure $\mathbf{S 3}{ }^{1} \mathrm{H}$ NMR(400 MHz) of 2 in DMSO- $d_{6}$

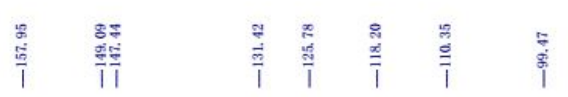

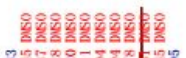

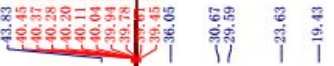
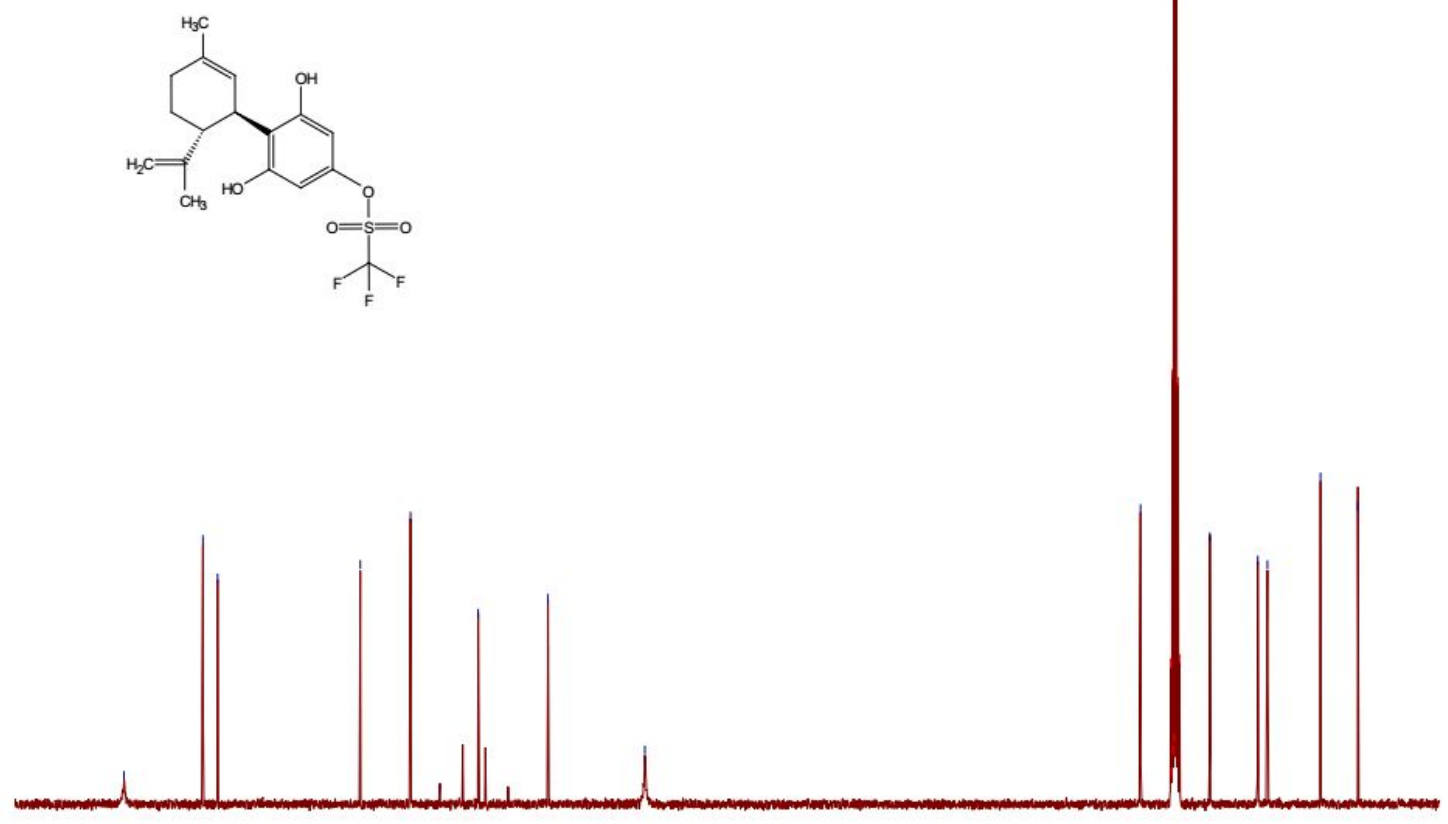

$\underset{70}{160} \quad 150 \cdot 140$

f1 (ppm)

Figure $\mathbf{S} 4{ }^{13} \mathrm{C}\left\{{ }^{1} \mathrm{H}\right\}$ NMR(125 MHz) of 2 in DMSO- $d_{6}$ 


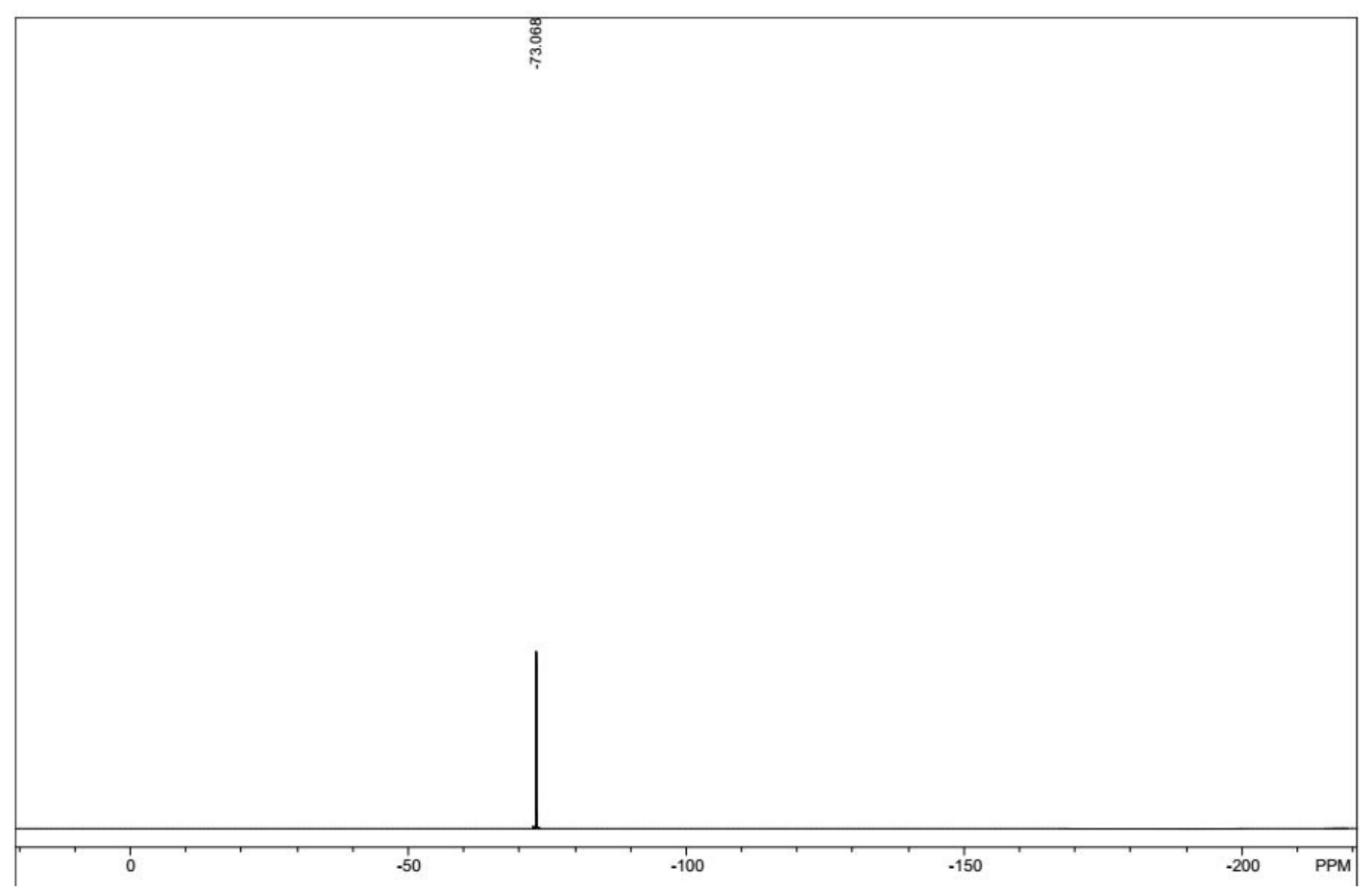

Figure S5 ${ }^{19} \mathrm{~F}-\mathrm{NMR}$ (470 MHz) of 2 in DMSO- $d_{6}$

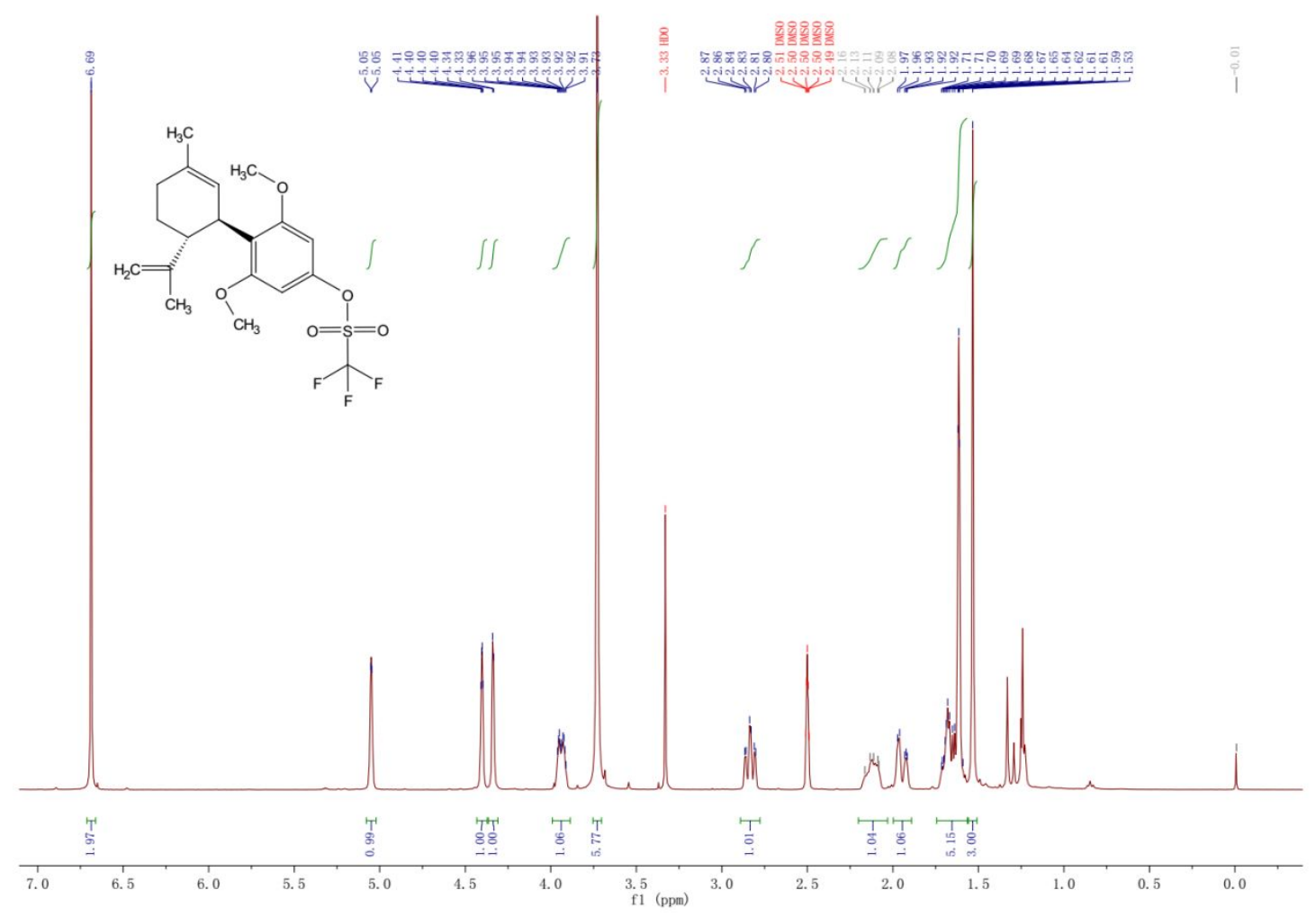

Figure $\mathbf{S 6}{ }^{1} \mathrm{H}$ NMR(400 MHz) of 3a in DMSO- $d_{6}$ 

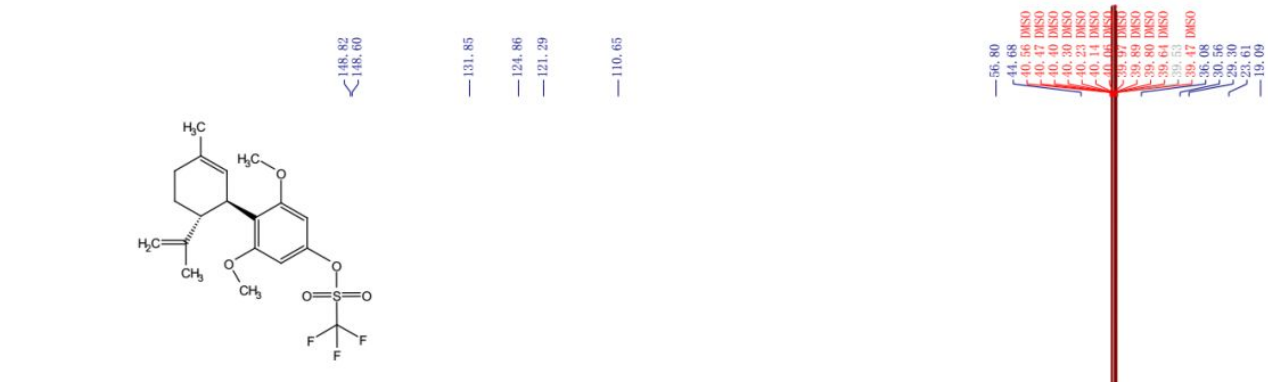

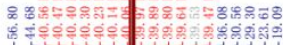

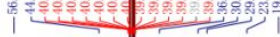
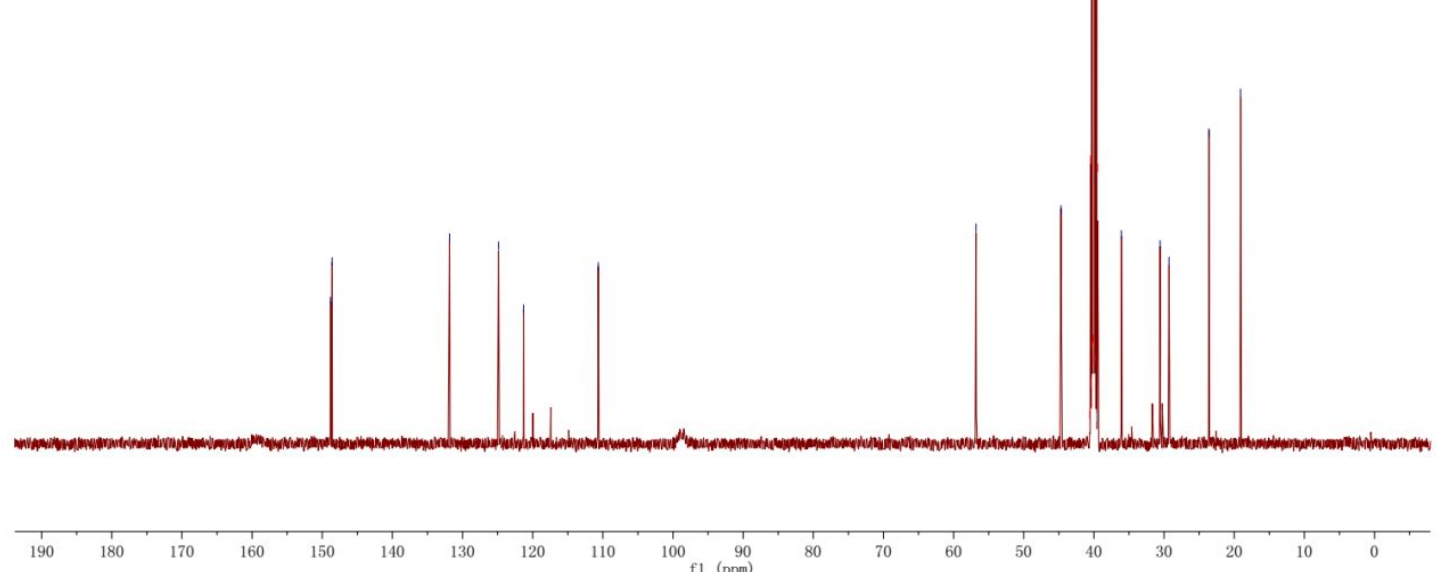

Figure $\mathbf{S} 7{ }^{13} \mathrm{C}\left\{{ }^{1} \mathrm{H}\right\} \mathrm{NMR}(125 \mathrm{MHz})$ of $\mathbf{3 a}$ in DMSO- $d_{6}$

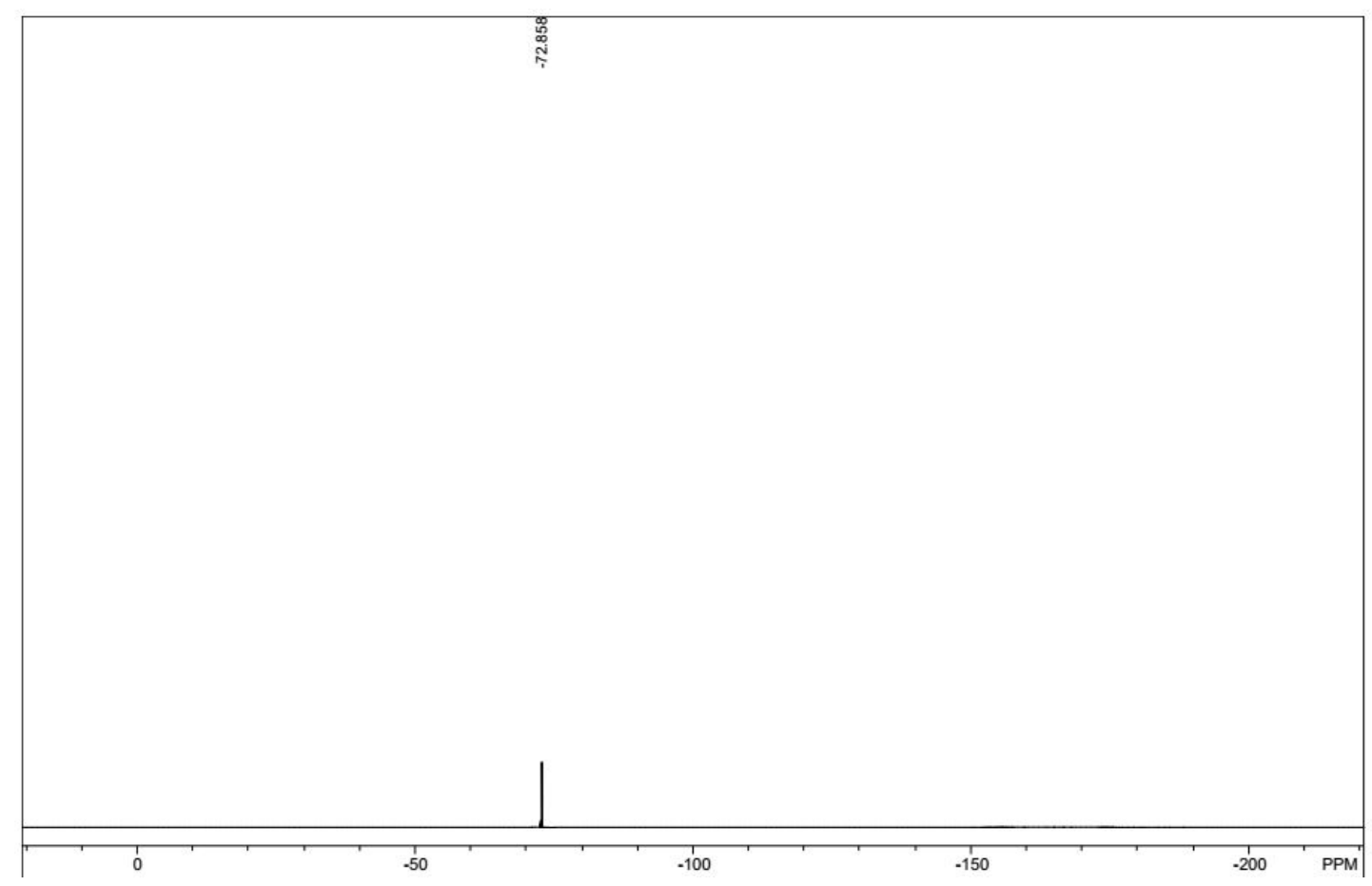

Figure S8 ${ }^{19} \mathrm{~F}-\mathrm{NMR}(470 \mathrm{MHz})$ of $\mathbf{3 a}$ in DMSO- $d_{6}$ 
<smiles>C=C(C)[C@@H]1CCC(C)=C[C@H]1c1c(OCC)cc(OCC)cc1OC(C)=O</smiles>

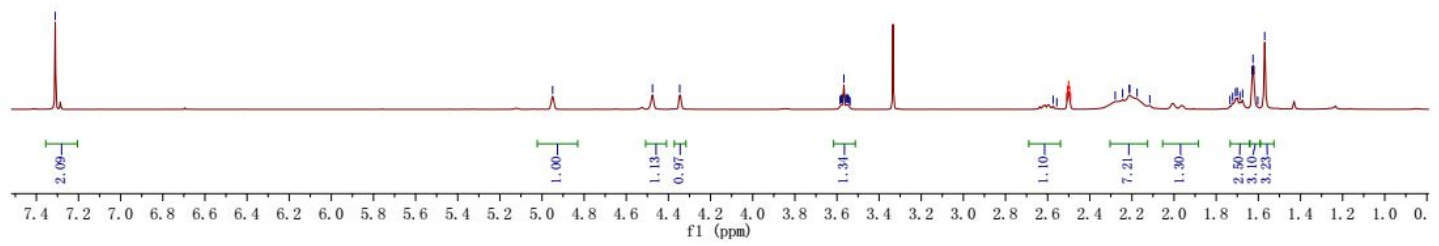

Figure S9 ${ }^{1} \mathrm{H}$ NMR(400 MHz) of $3 \mathbf{b}$ in DMSO- $d_{6}$

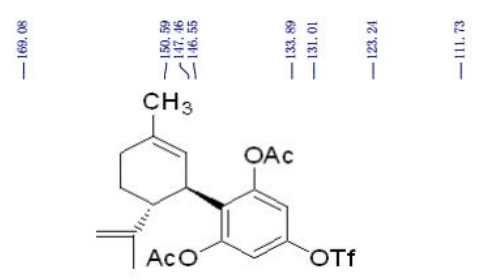

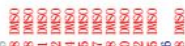

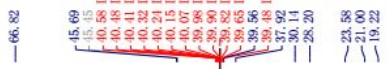

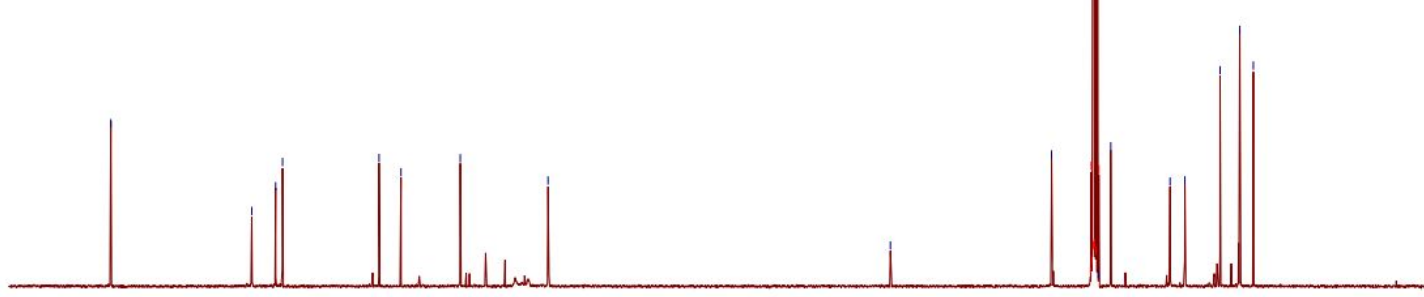

Figure S10 ${ }^{13} \mathrm{C}\left\{{ }^{1} \mathrm{H}\right\} \mathrm{NMR}(125 \mathrm{MHz})$ of $\mathbf{3 b}$ in DMSO- $d_{6}$ 

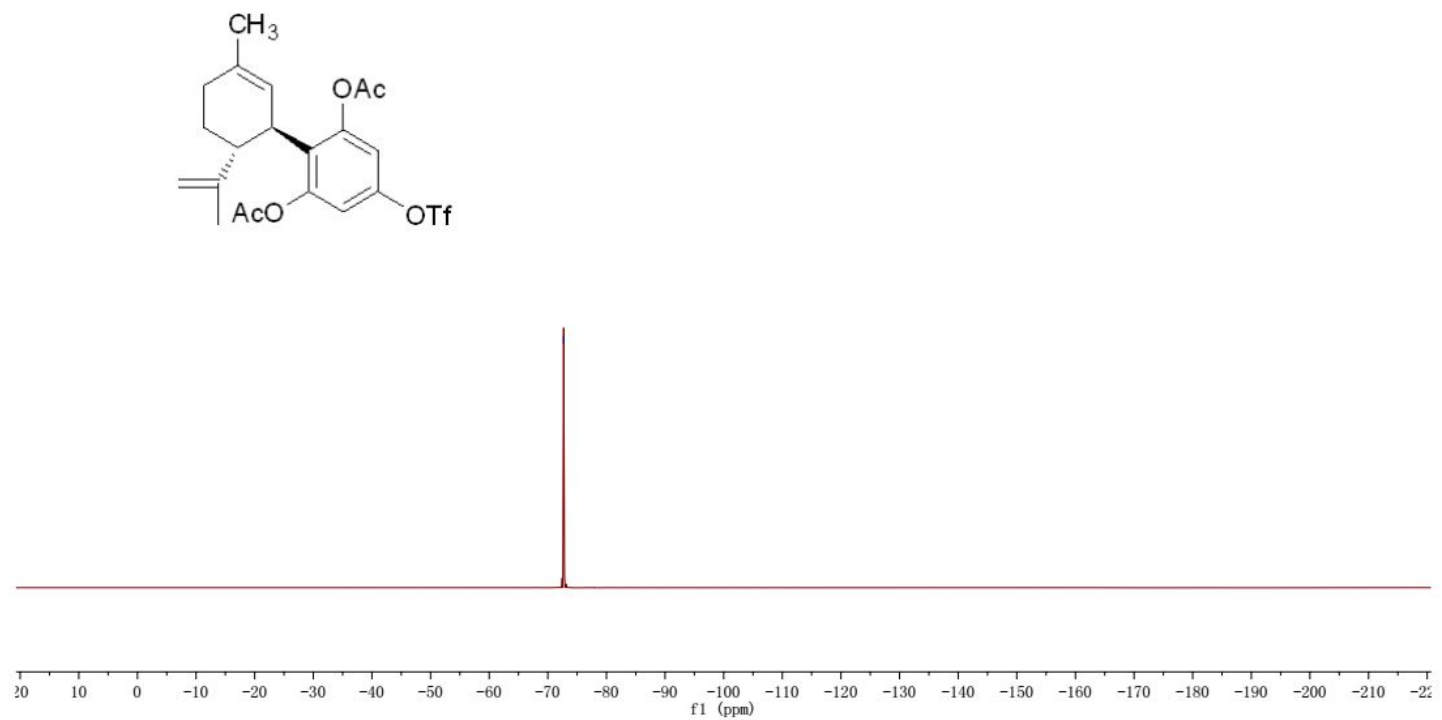

Figure S11 ${ }^{19} \mathrm{~F}-\mathrm{NMR}(470 \mathrm{MHz})$ of $\mathbf{3 b}$ in DMSO- $d_{6}$

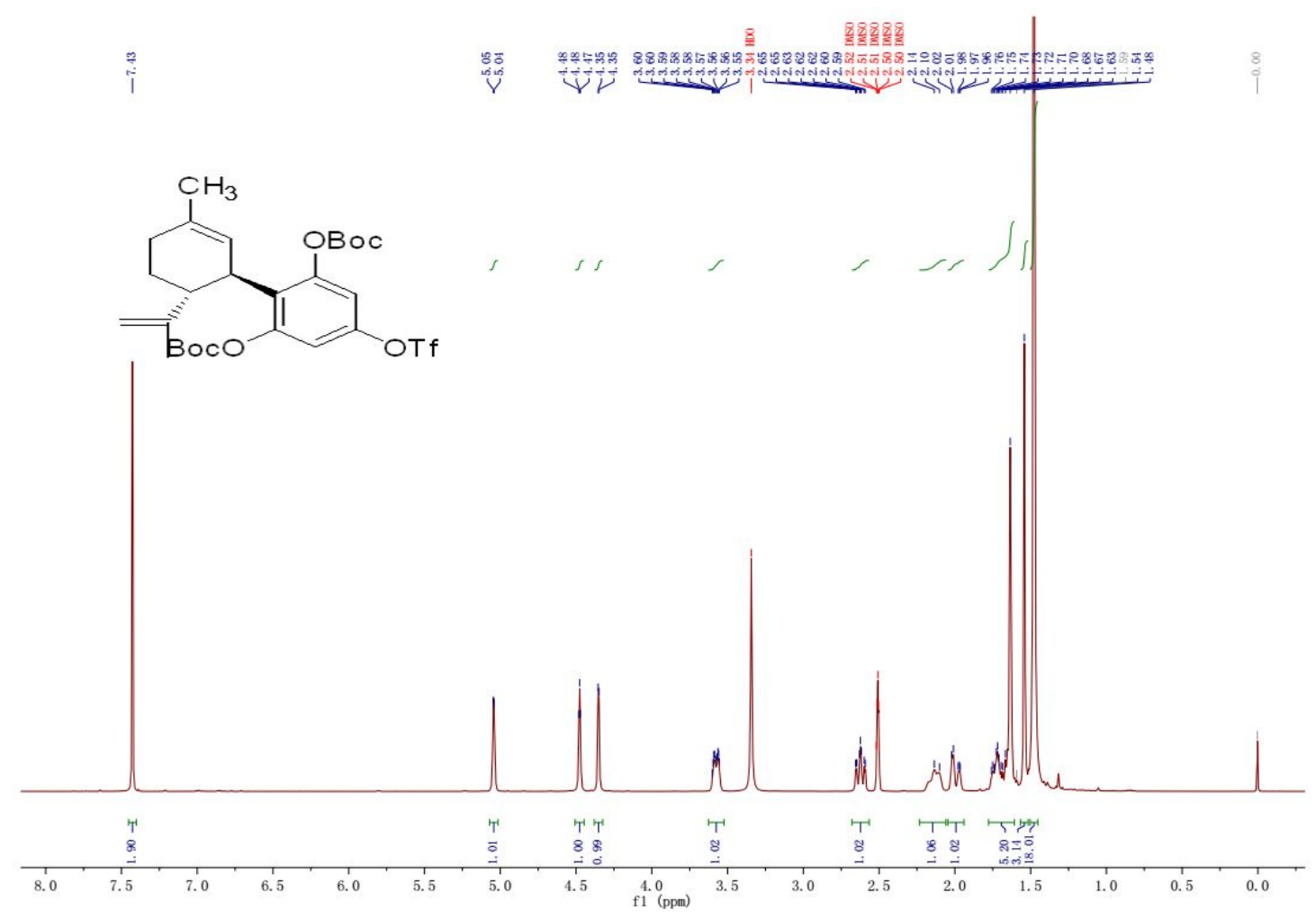

Figure S12 ${ }^{1} \mathrm{H}$ NMR(400 MHz) of 3d in DMSO- $d_{6}$ 


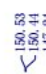
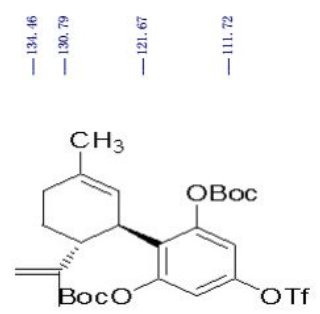

BocO OTf
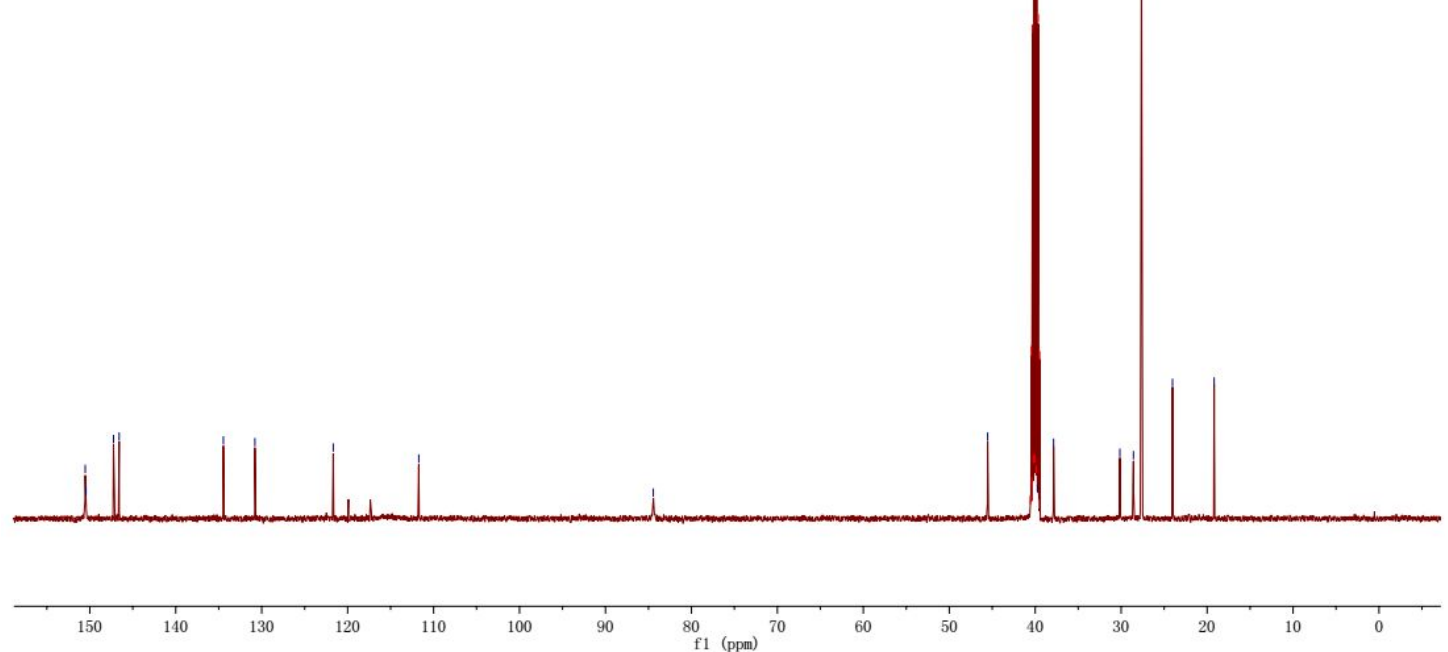

Figure S13 ${ }^{13} \mathrm{C}\left\{{ }^{1} \mathrm{H}\right\}$ NMR(125 MHz) of 3d in DMSO- $d_{6}$

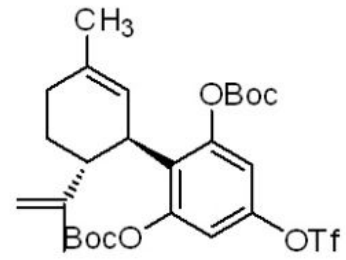

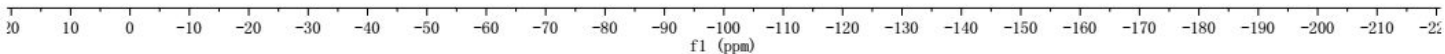

Figure S14 ${ }^{19}$ F-NMR $(470 \mathrm{MHz})$ of $\mathbf{3 d}$ in DMSO- $d_{6}$ 


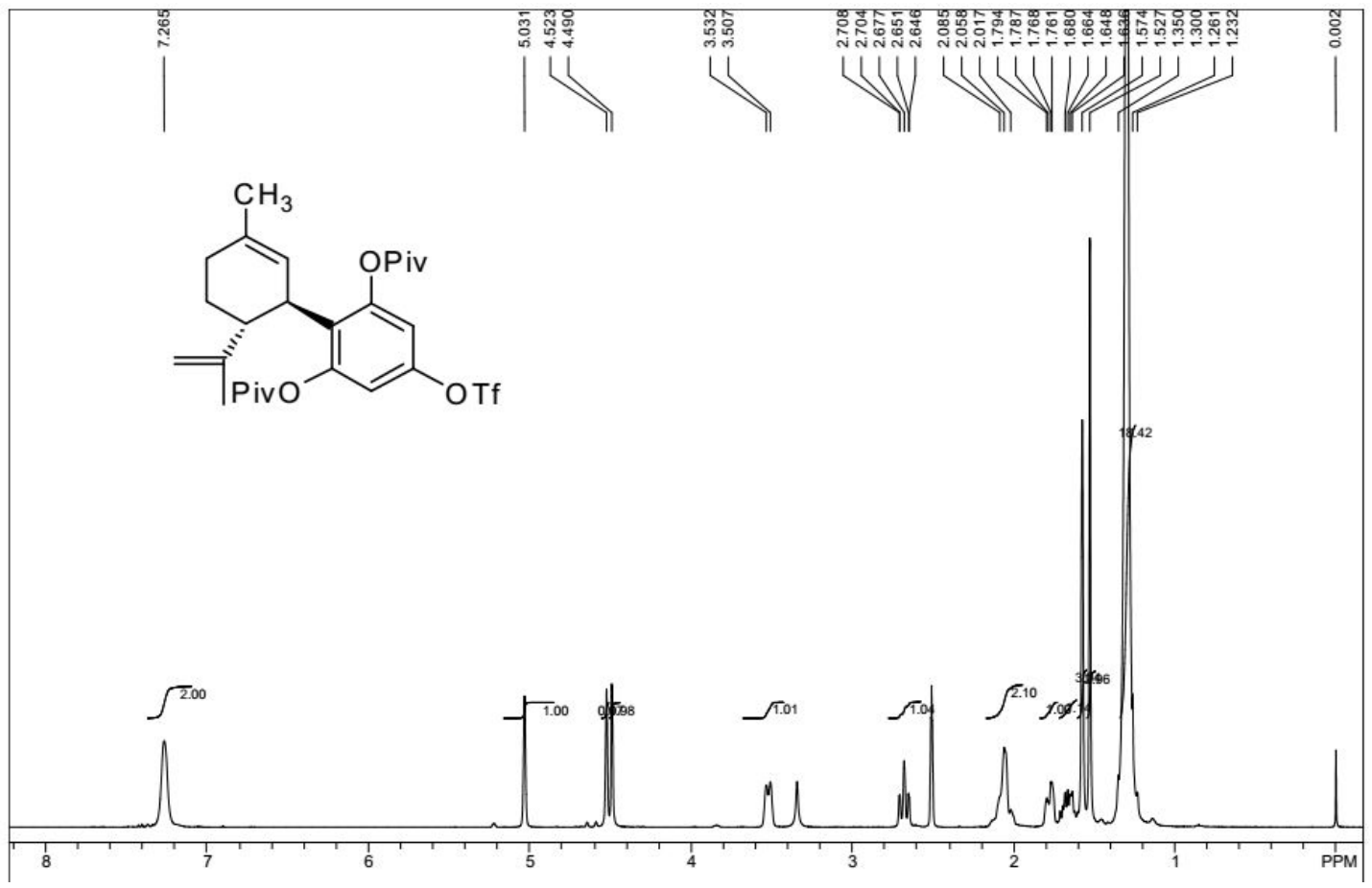

Figure $\mathbf{S 1 5}{ }^{1} \mathrm{H}$ NMR(400 MHz) of $3 \mathbf{e}$ in DMSO- $d_{6}$
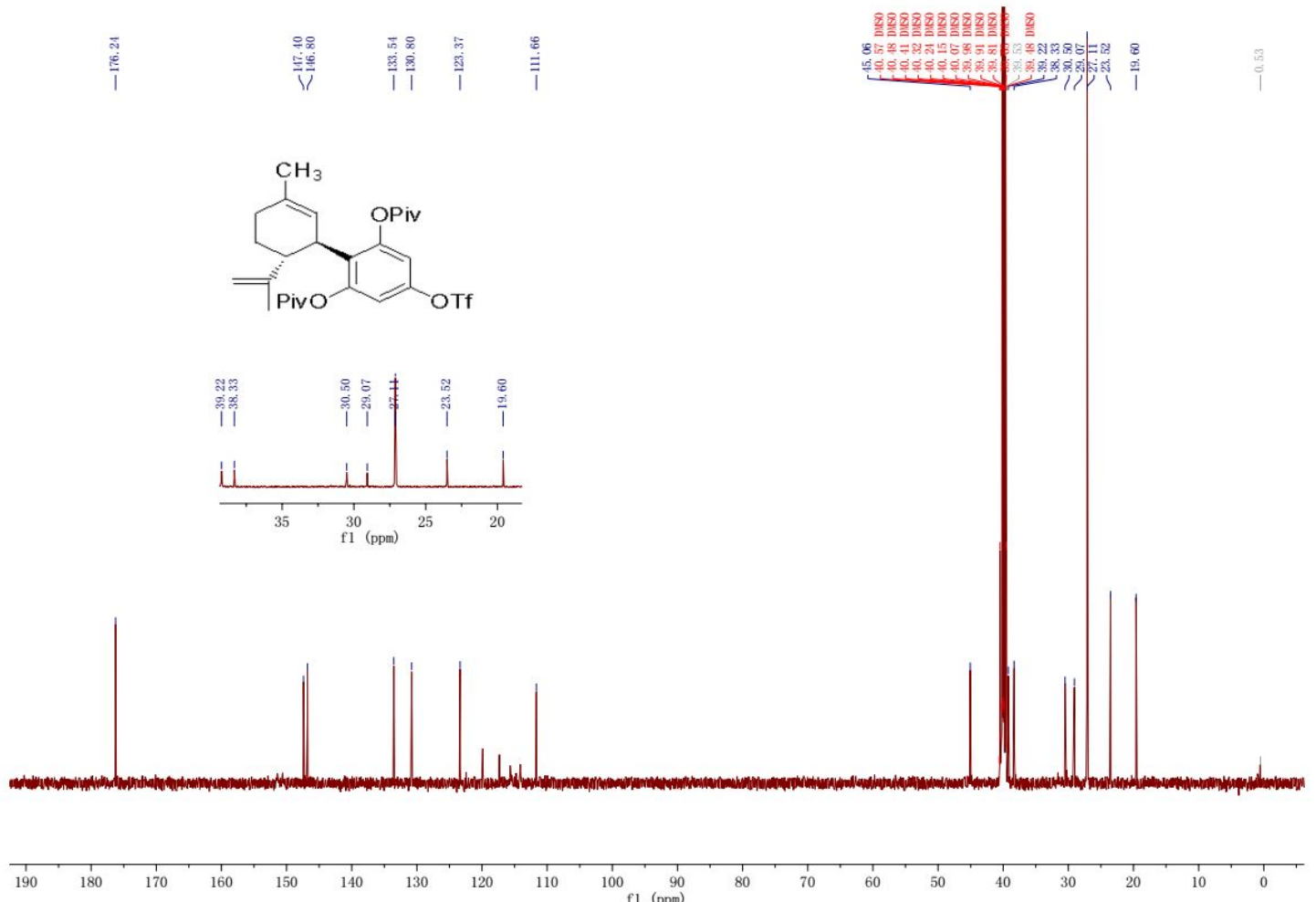

Figure $\mathbf{S 1 6}{ }^{13} \mathrm{C}\left\{{ }^{1} \mathrm{H}\right\}$ NMR(125 MHz) of $\mathbf{3 e}$ in DMSO- $d_{6}$ 


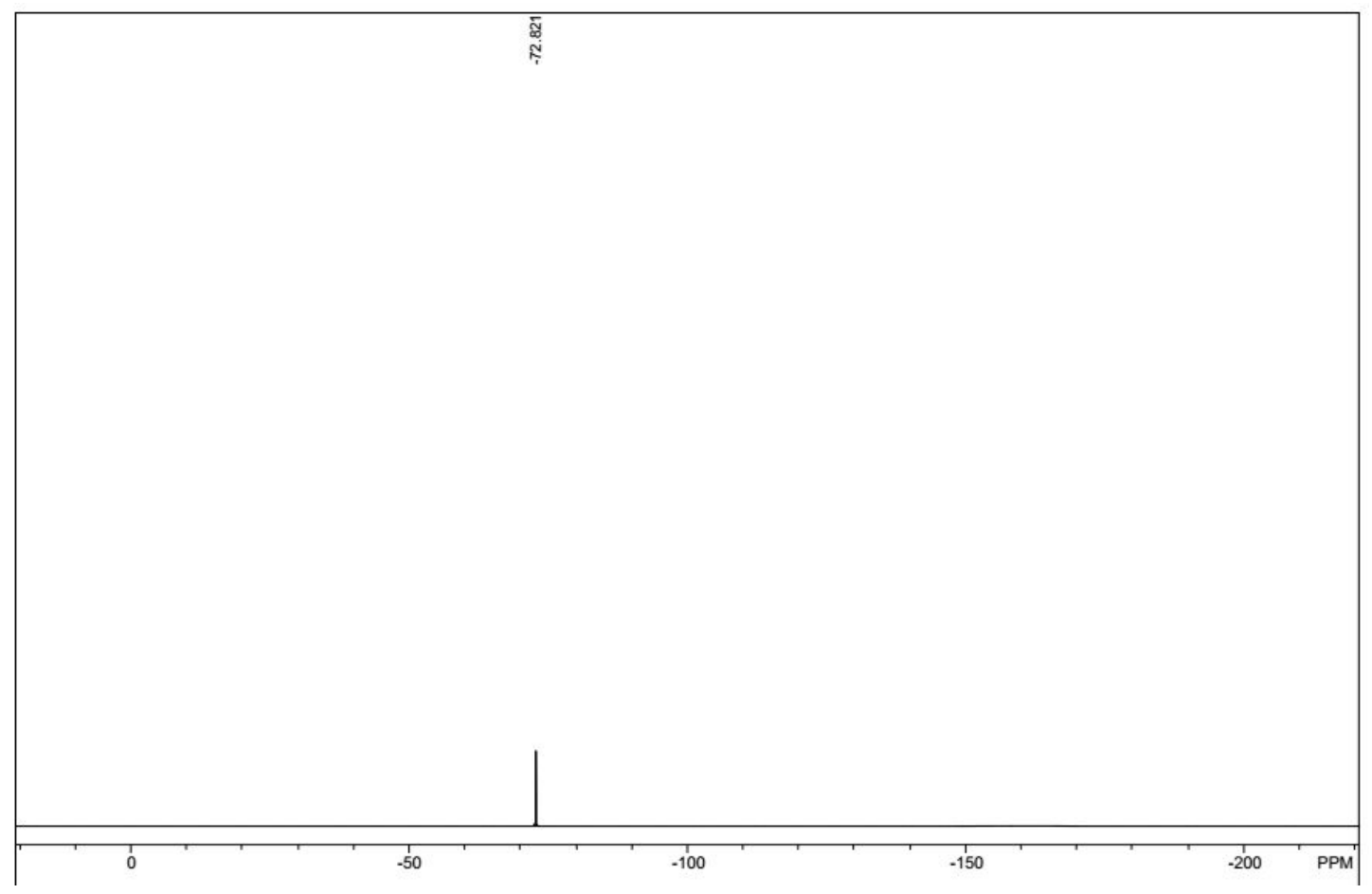

Figure S17 ${ }^{19} \mathrm{~F}-\mathrm{NMR}(470 \mathrm{MHz})$ of $\mathbf{3 e}$ in DMSO- $d_{6}$

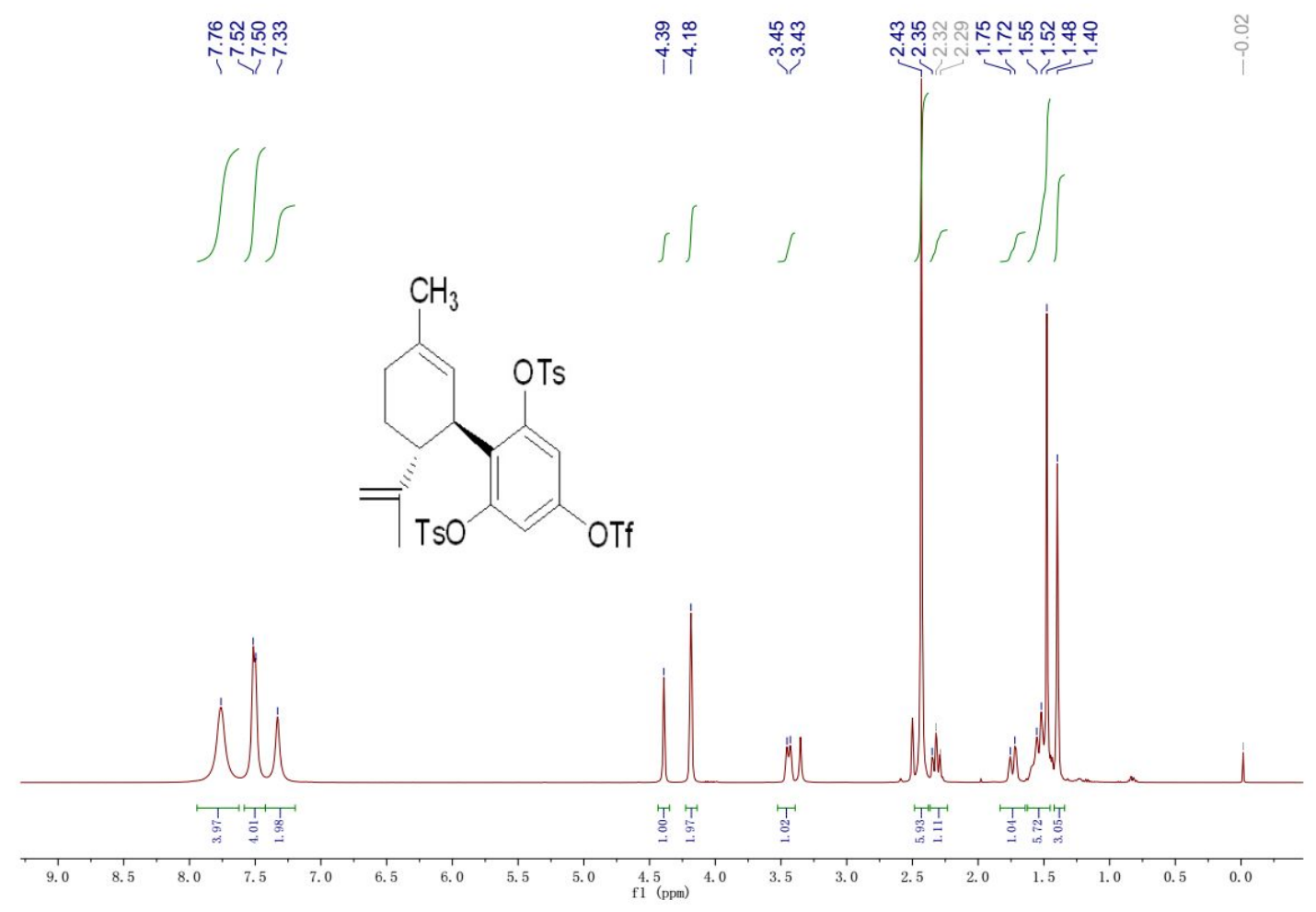

Figure $\mathbf{S 1 8}{ }^{1} \mathrm{H}$ NMR(400 MHz) of $\mathbf{3 f}$ in DMSO- $d_{6}$ 


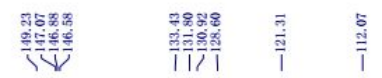
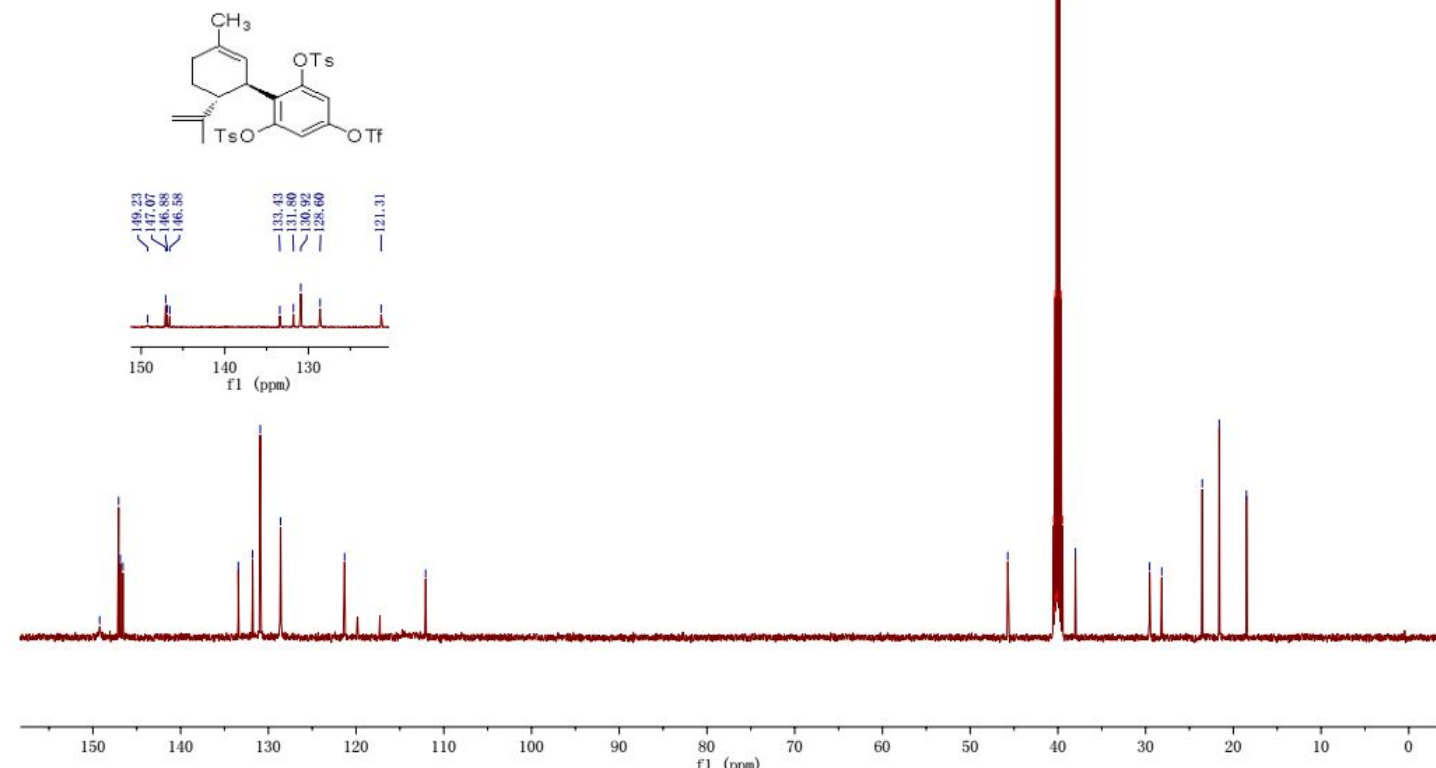

1 进

Figure S19 ${ }^{13} \mathrm{C}\left\{{ }^{1} \mathrm{H}\right\} \mathrm{NMR}(125 \mathrm{MHz})$ of $\mathbf{3 f}$ in DMSO- $d_{6}$ సָi<smiles>C=C(C)[C@H]1CCC(C)=C[C@H]1c1c(O)cc([SeH])cc1[OH2+]</smiles>

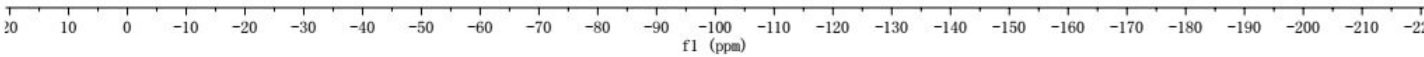

Figure S20 ${ }^{19} \mathrm{~F}-\mathrm{NMR}(470 \mathrm{MHz})$ of $\mathbf{3 f}$ in $\mathrm{DMSO}-d_{6}$ 


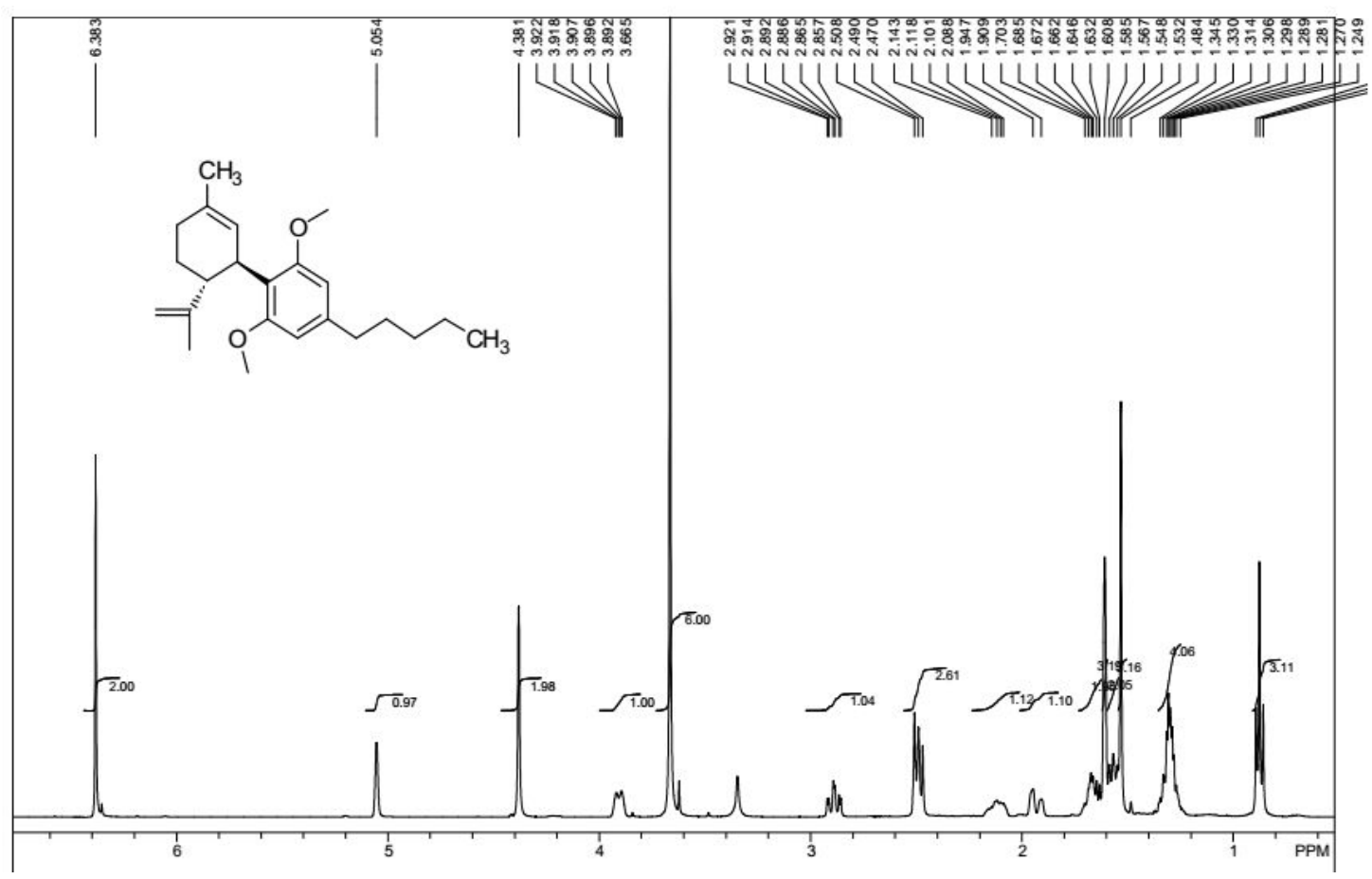

Figure S21 ${ }^{1} \mathrm{H}$ NMR(400 MHz) of 4aa in DMSO- $d_{6}$

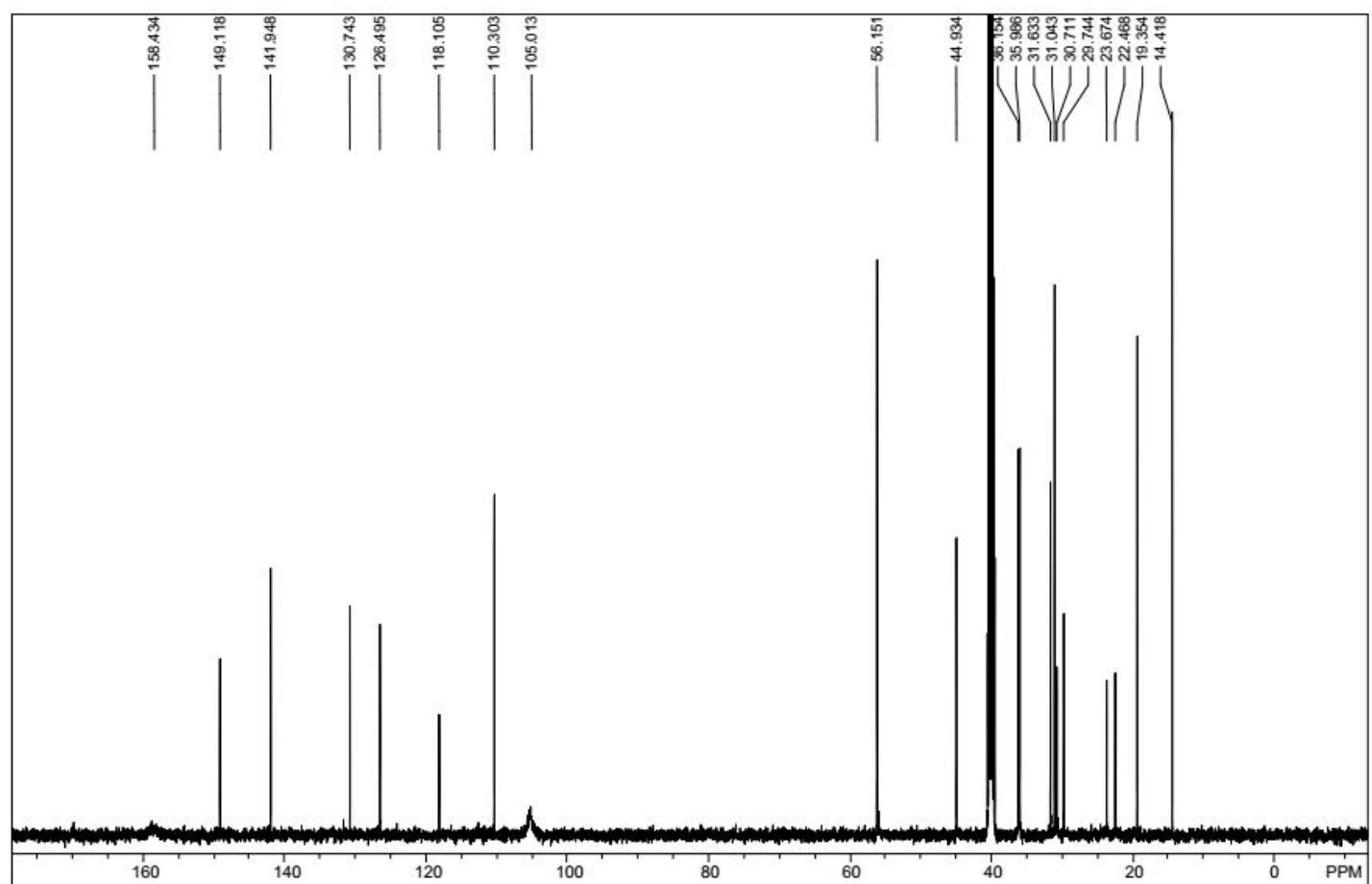

Figure $\mathbf{S 2 2}{ }^{13} \mathrm{C}\left\{{ }^{1} \mathrm{H}\right\} \mathrm{NMR}(125 \mathrm{MHz})$ of $\mathbf{4 a a}$ in DMSO- $d_{6}$ 

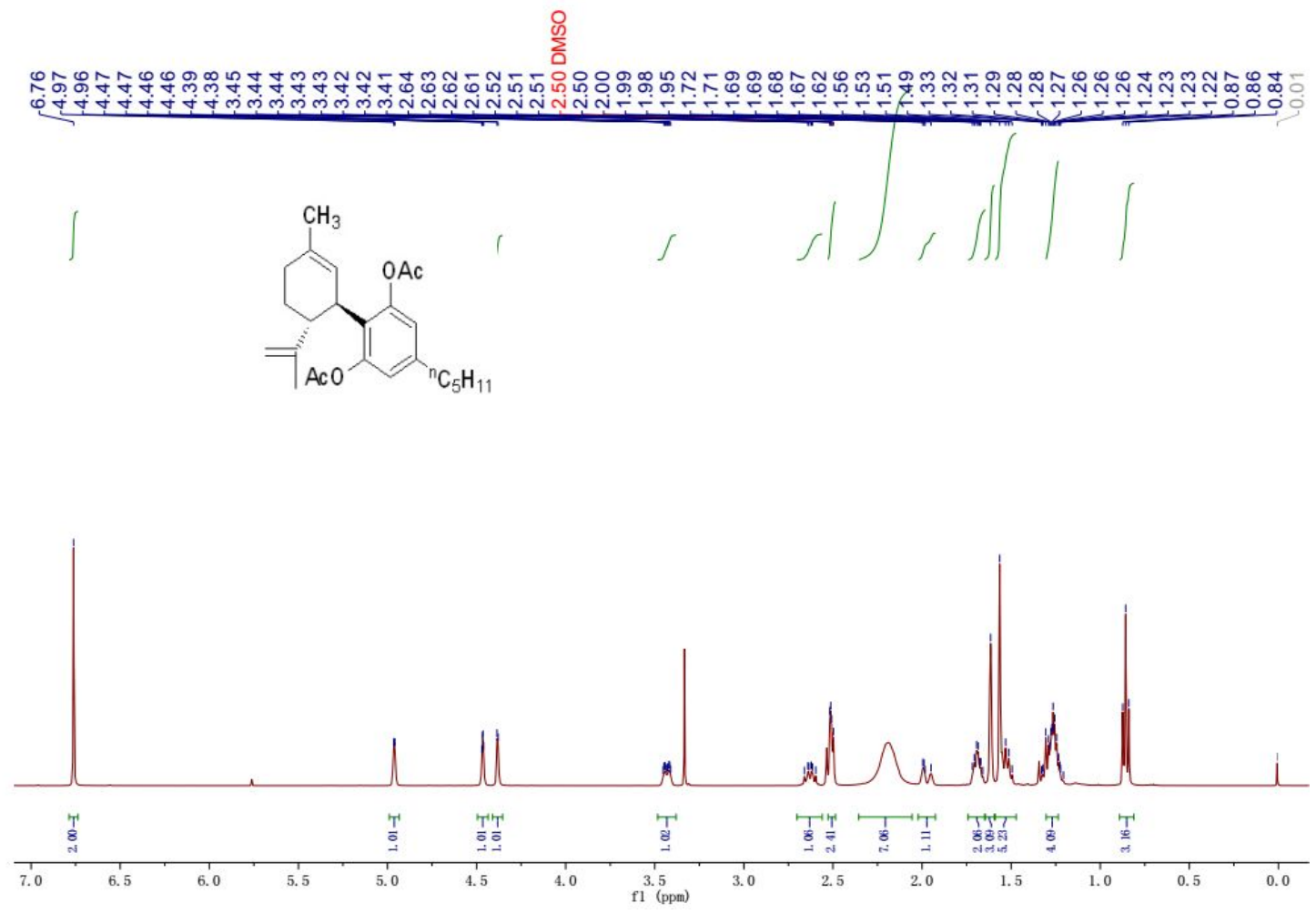

Figure $\mathbf{S 2 3}{ }^{1} \mathrm{H}$ NMR(400 MHz) of $\mathbf{4 b a}$ in DMSO- $d_{6}$

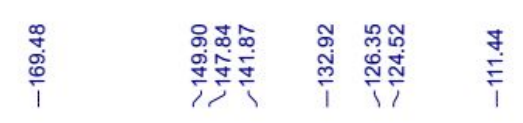
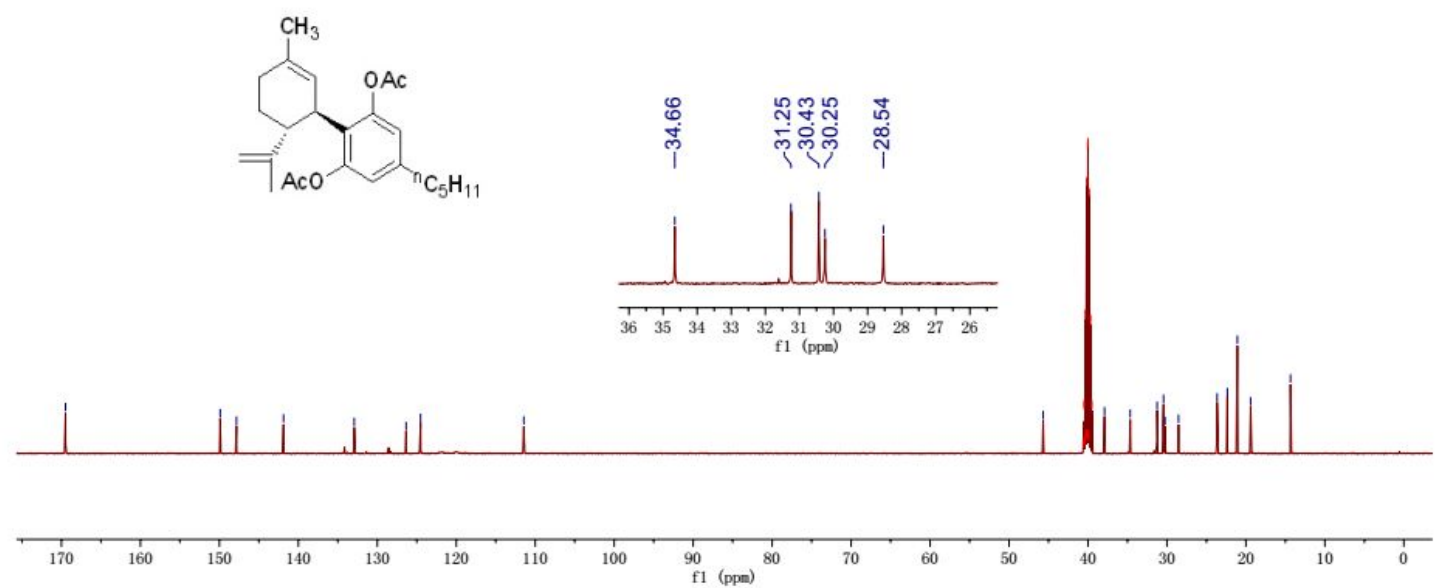

Figure $\mathbf{S 2 4}{ }^{13} \mathrm{C}\left\{{ }^{1} \mathrm{H}\right\}$ NMR $(125 \mathrm{MHz})$ of $\mathbf{4 b a}$ in DMSO- $d_{6}$ 


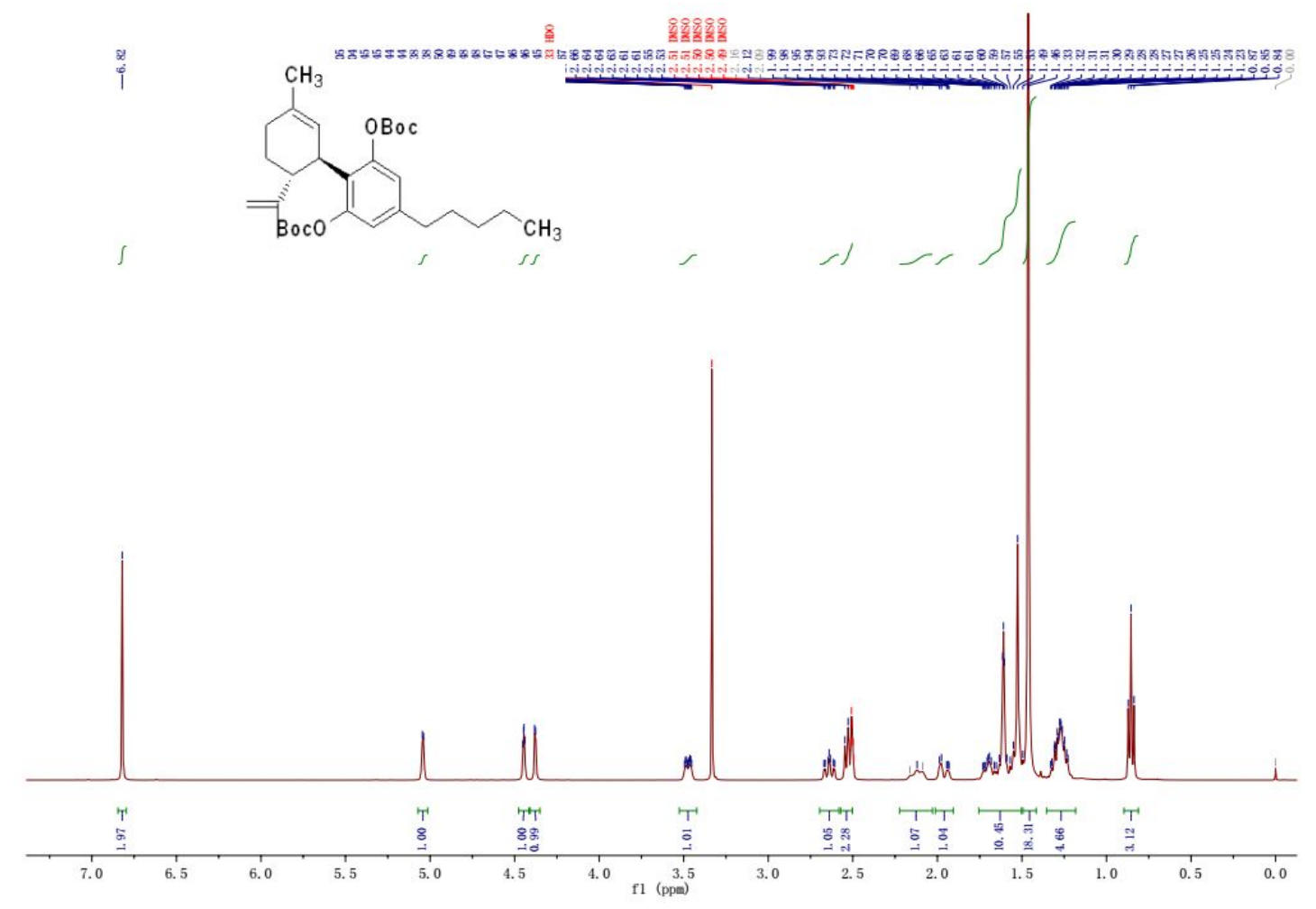

Figure $\mathbf{S 2 5}{ }^{1} \mathrm{H}$ NMR(400 MHz) of $\mathbf{4 d a}$ in DMSO- $d_{6}$
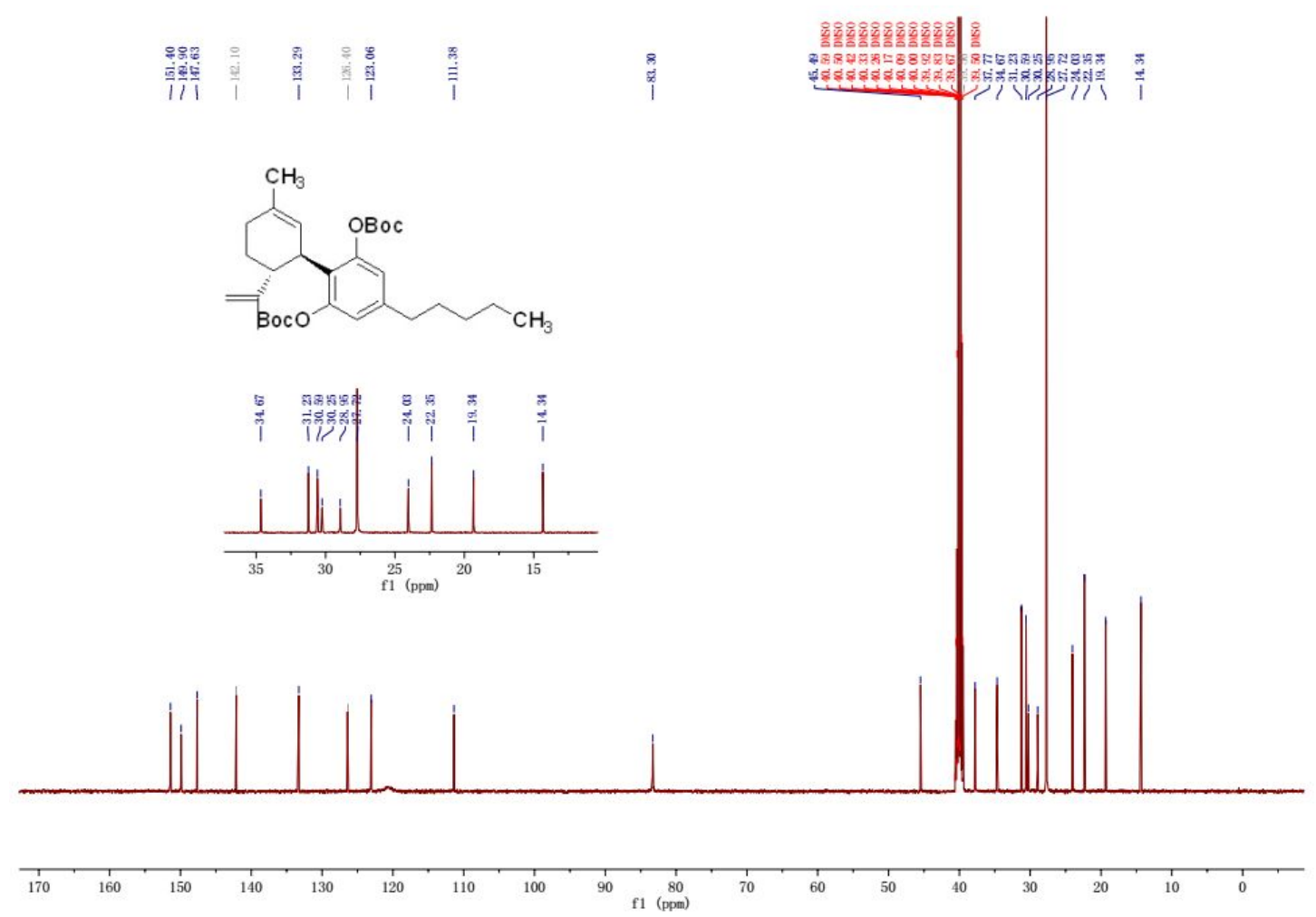

Figure S26 ${ }^{13} \mathrm{C}\left\{{ }^{1} \mathrm{H}\right\}$ NMR(125 MHz) of $\mathbf{4 d a}$ in DMSO- $d_{6}$ 


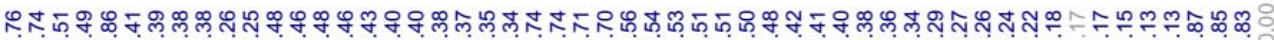

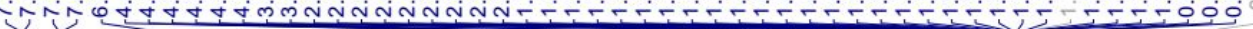
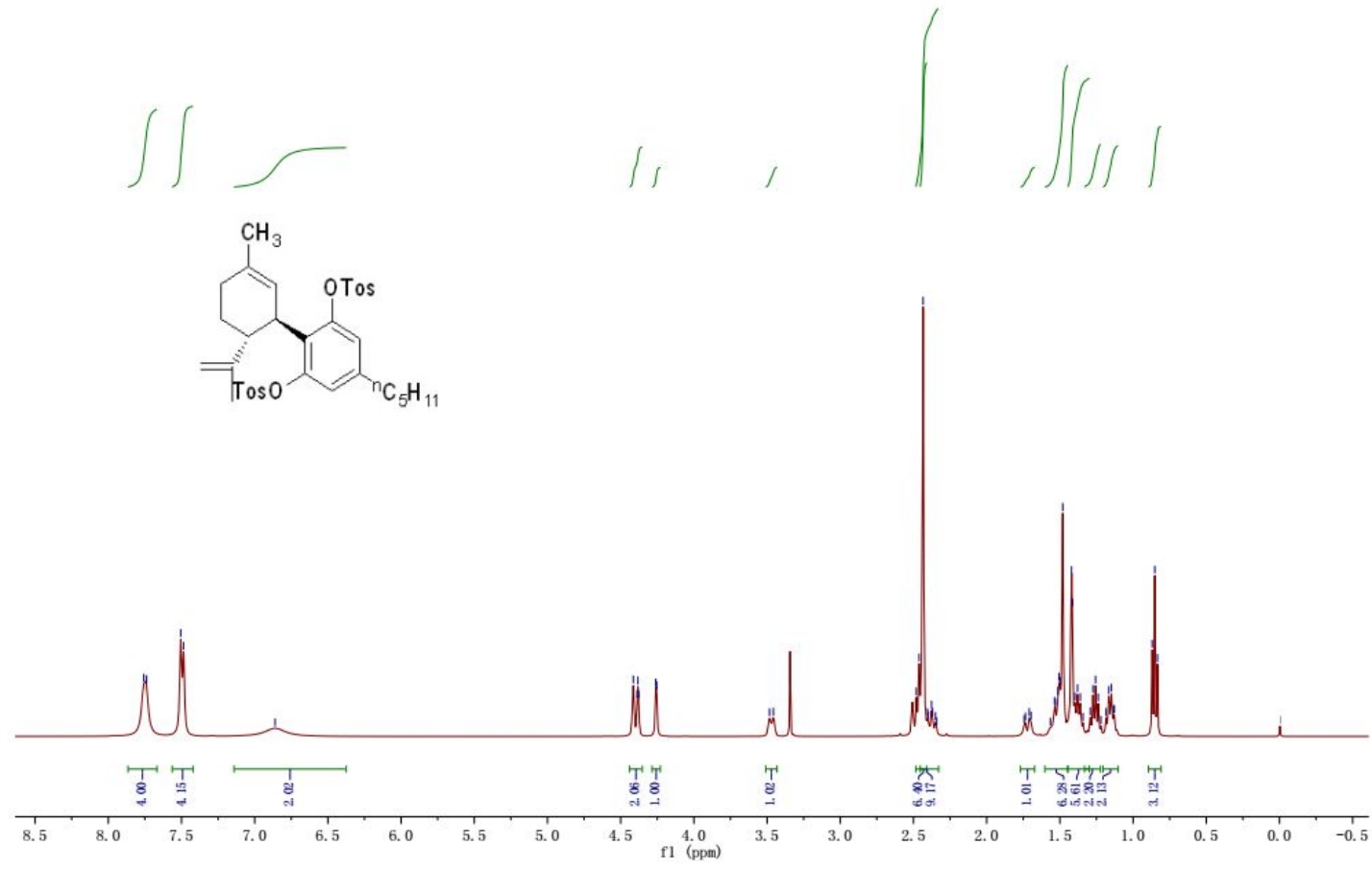

Figure $\mathbf{S 2 7}{ }^{1} \mathrm{H}$ NMR $(400 \mathrm{MHz})$ of $\mathbf{4 f a}$ in DMSO- $d_{6}$
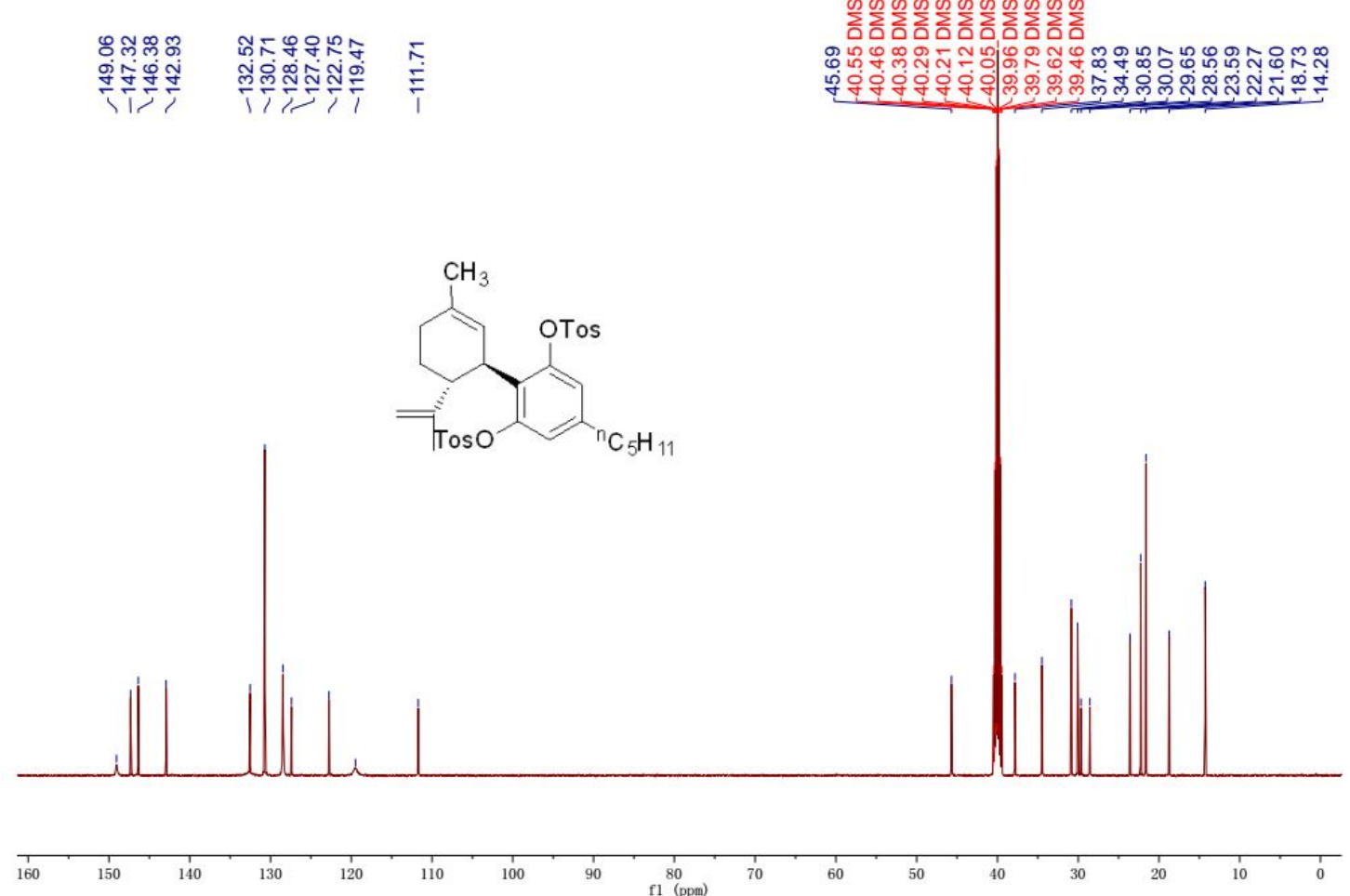

Figure $\mathbf{S 2 8}{ }^{13} \mathrm{C}\left\{{ }^{1} \mathrm{H}\right\}$ NMR(125 MHz) of $\mathbf{4 f a}$ in DMSO- $d_{6}$ 


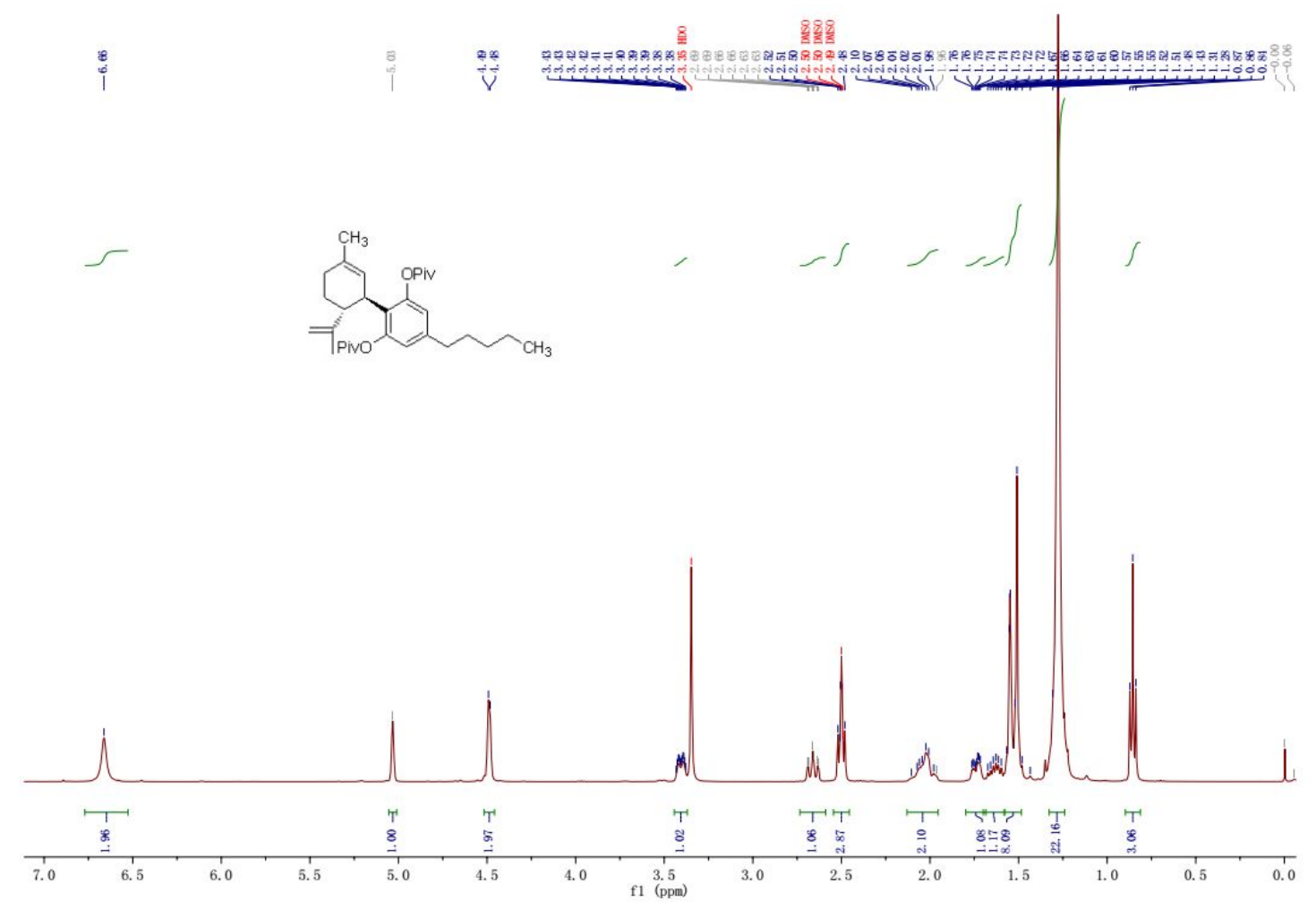

Figure S29 ${ }^{1} \mathrm{H}$ NMR(400 MHz) of $\mathbf{4 e a}$ in DMSO- $d_{6}$

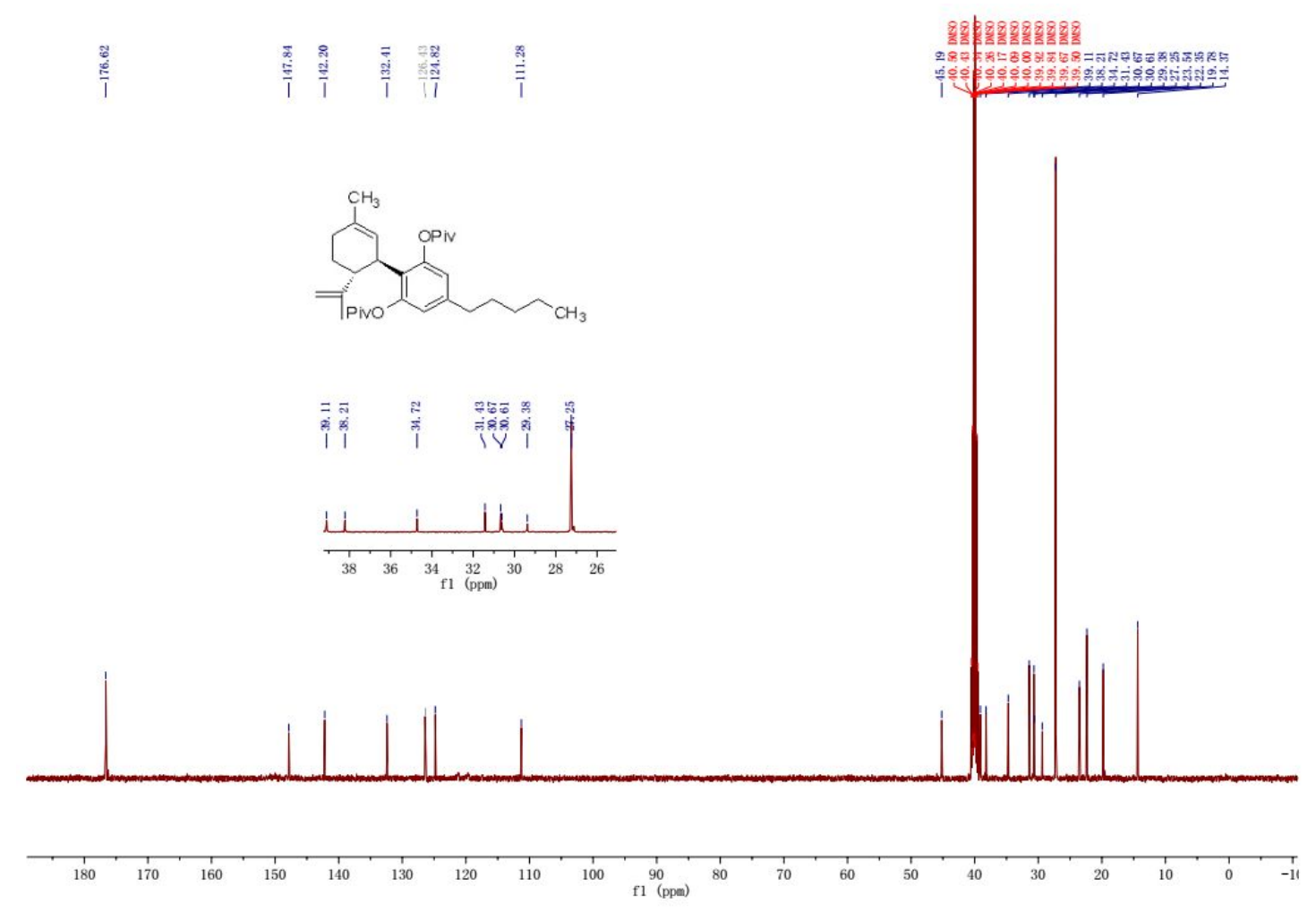

Figure S30 ${ }^{13} \mathrm{C}\left\{{ }^{1} \mathrm{H}\right\} \mathrm{NMR}(125 \mathrm{MHz})$ of 4 ea in DMSO- $d_{6}$ 


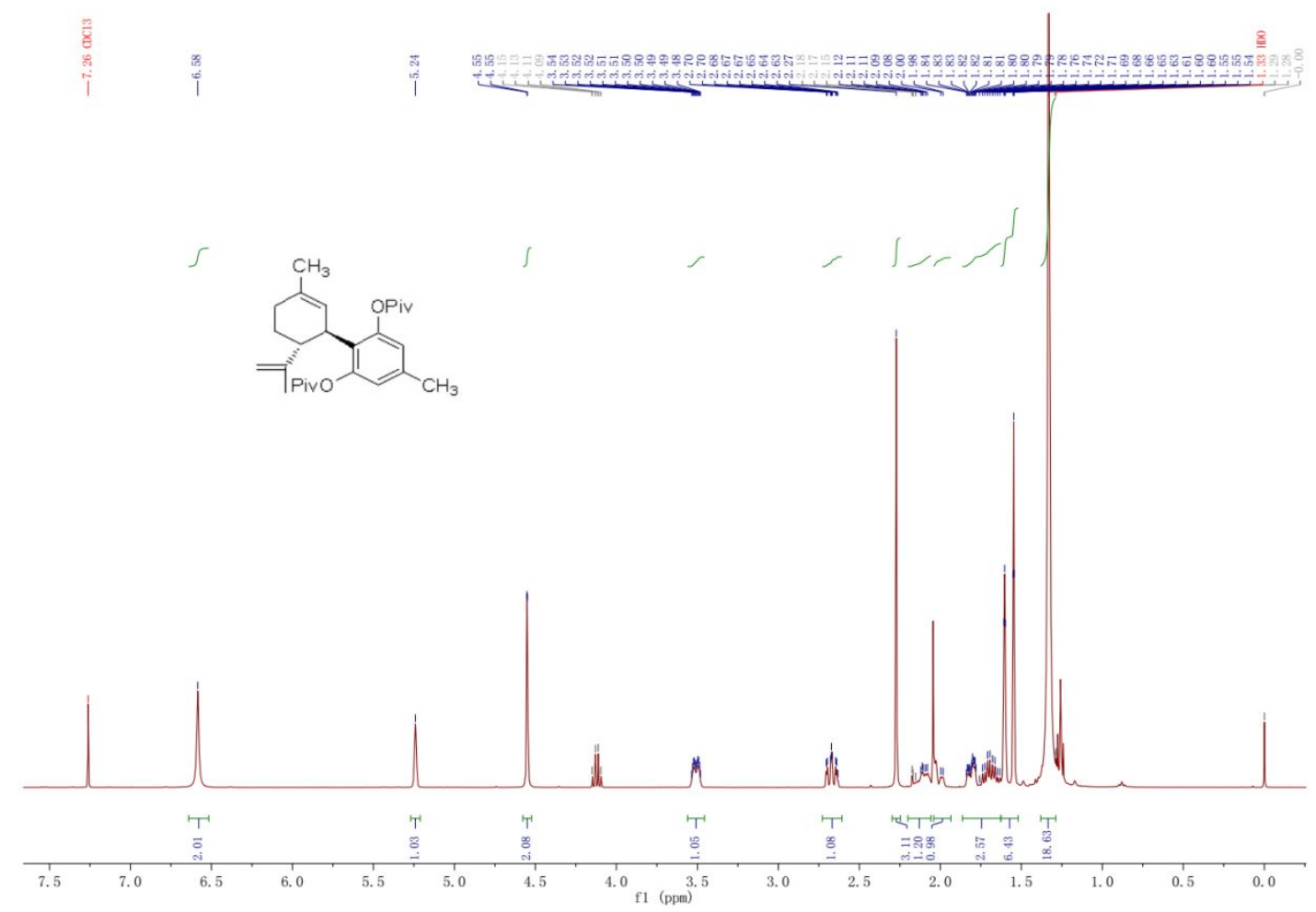

Figure S31 ${ }^{1} \mathrm{H}$ NMR(400 MHz) of $4 \mathbf{e b}$ in $\mathrm{CDCl}_{3}$

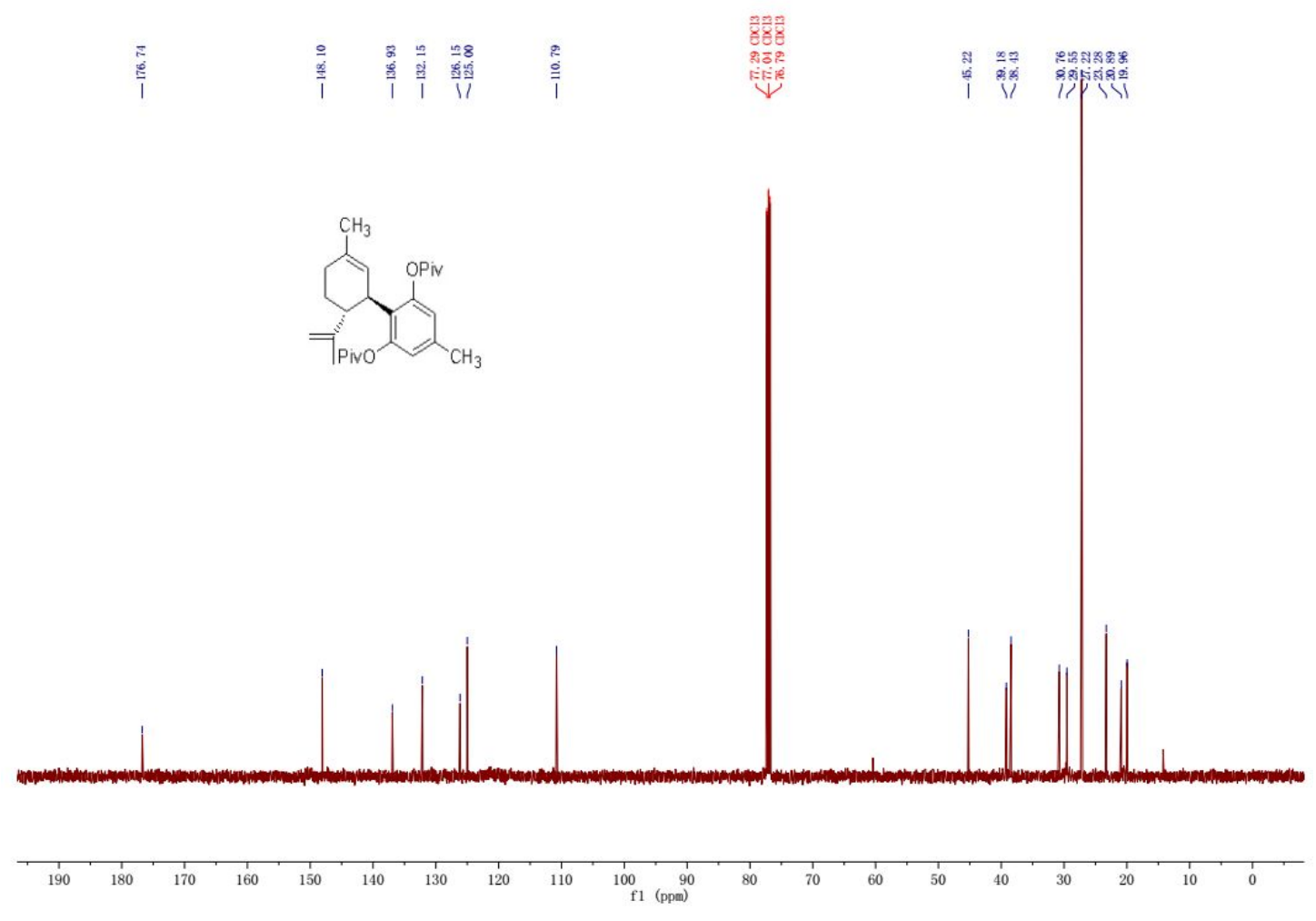

Figure $\mathbf{S 3 2}{ }^{13} \mathrm{C}\left\{{ }^{1} \mathrm{H}\right\} \mathrm{NMR}(125 \mathrm{MHz})$ of $\mathbf{4 e b}$ in $\mathrm{CDCl}_{3}$ 


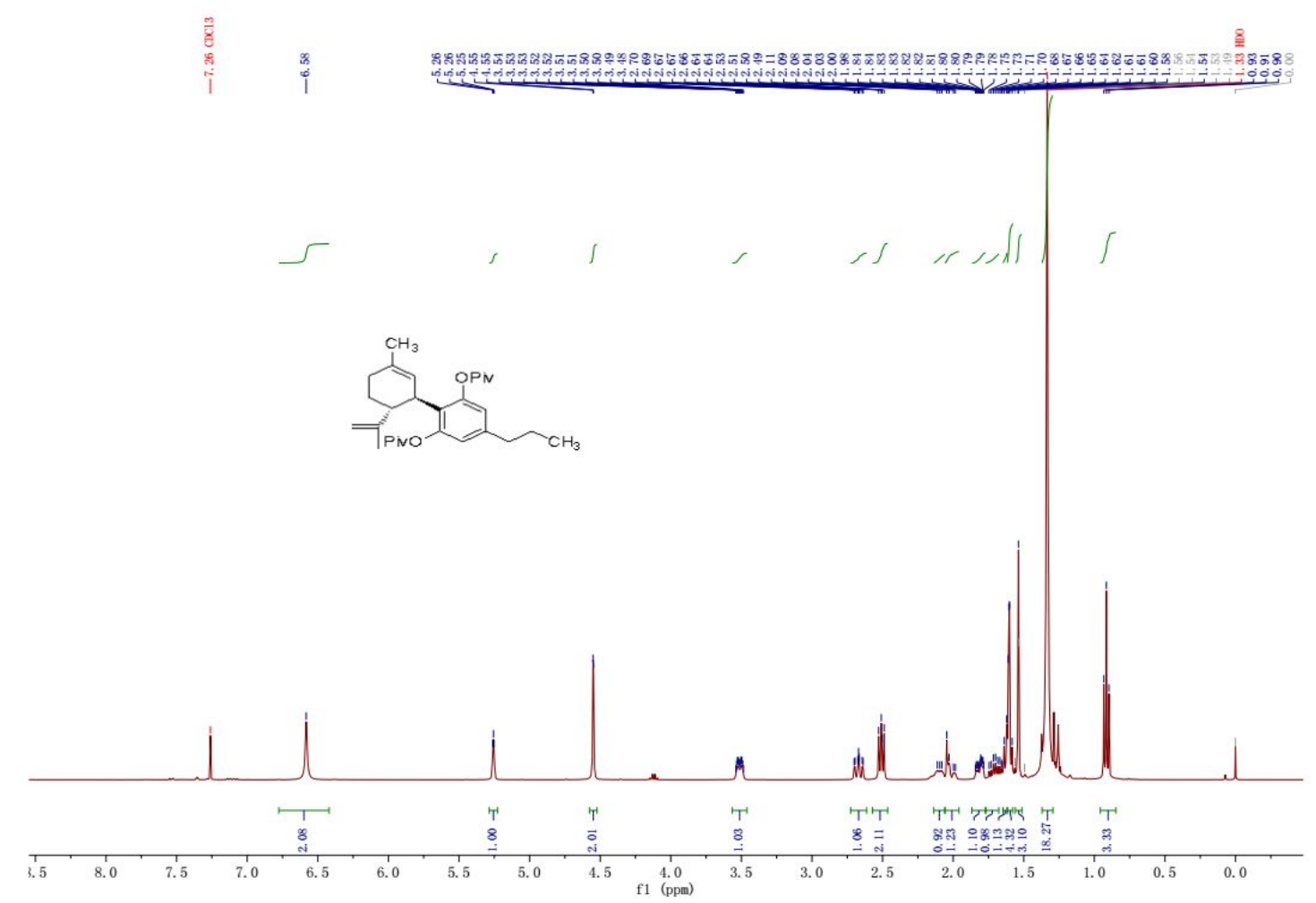

Figure $\mathbf{S 3 3}{ }^{1} \mathrm{H}$ NMR(400 MHz) of 4ec in $\mathrm{CDCl}_{3}$
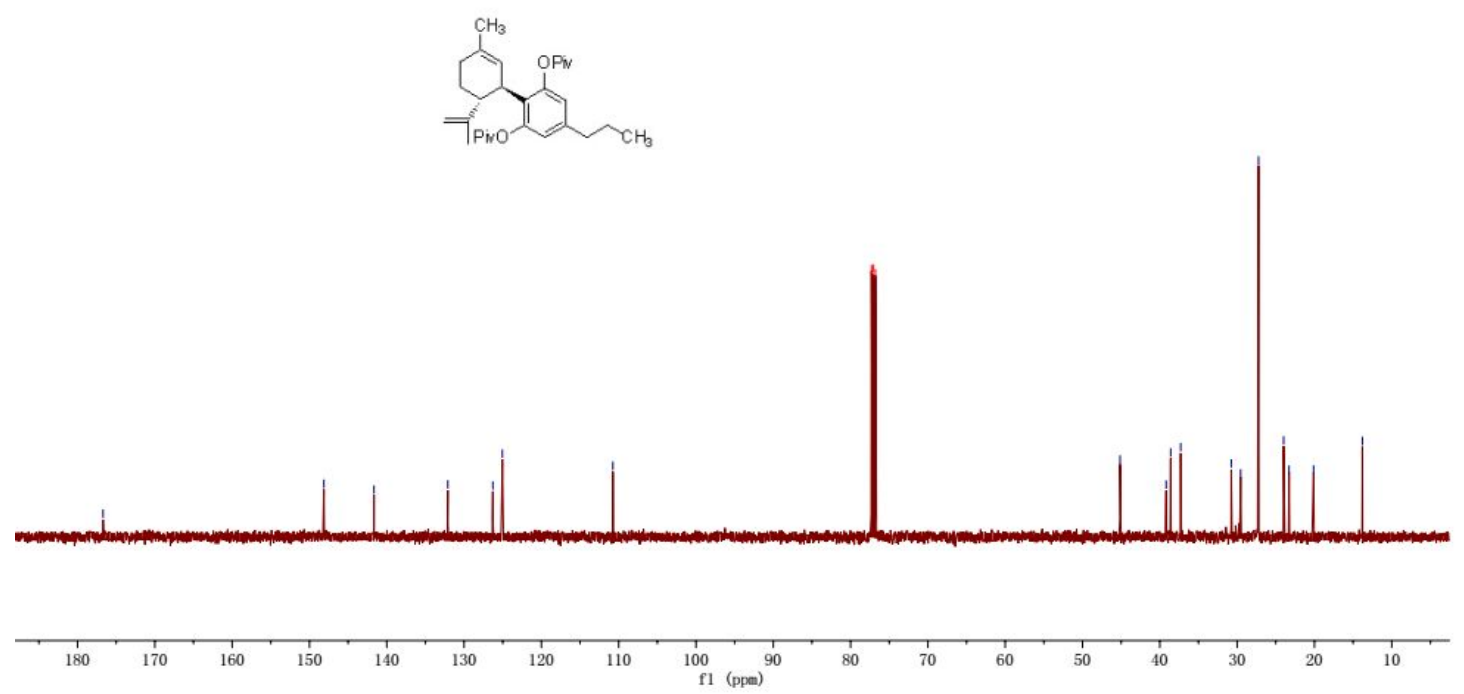

Figure $\mathbf{S 3 4}{ }^{13} \mathrm{C}\left\{{ }^{1} \mathrm{H}\right\} \mathrm{NMR}(125 \mathrm{MHz})$ of $4 \mathbf{e c}$ in $\mathrm{CDCl}_{3}$ 


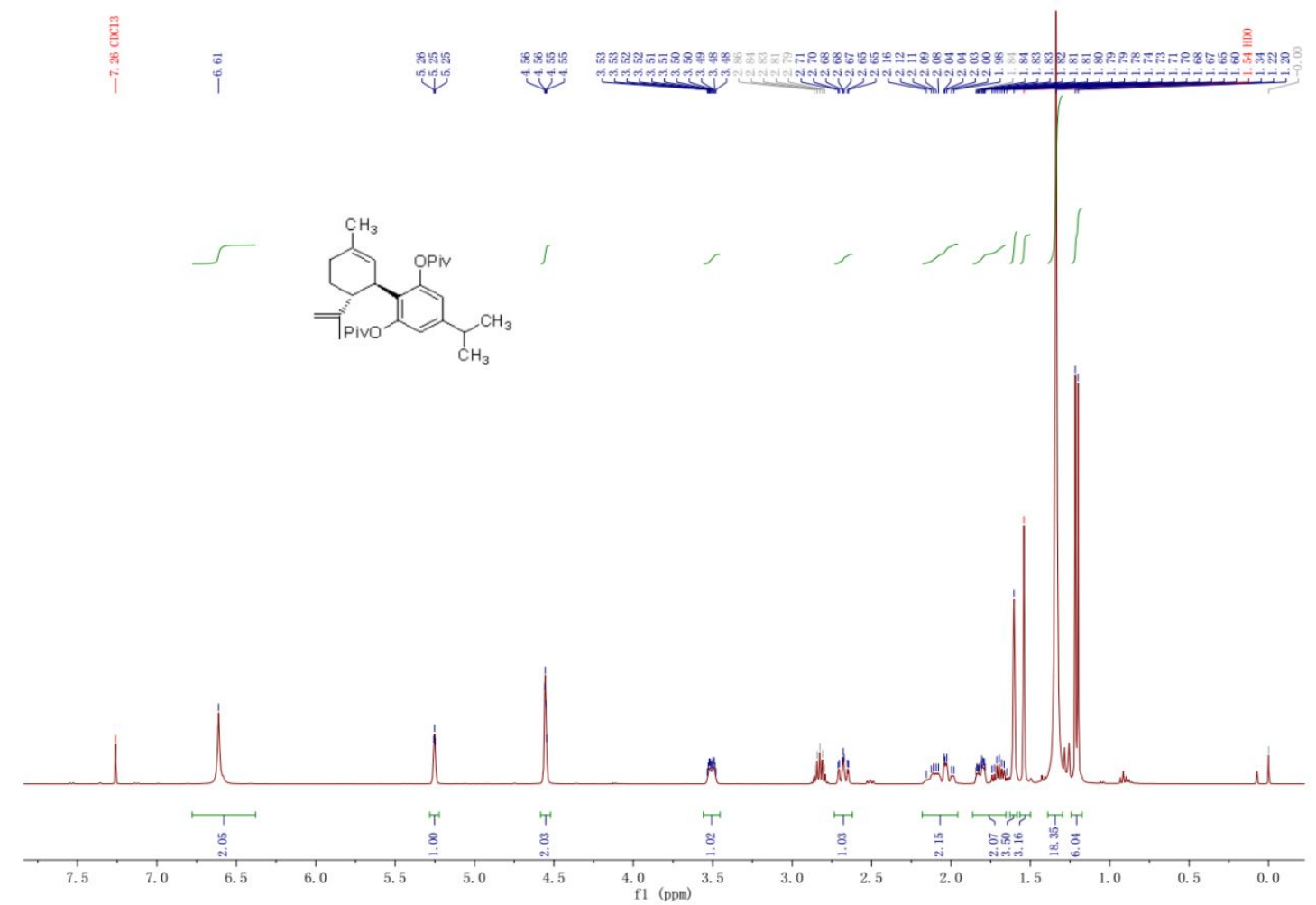

Figure $\mathbf{S 3 5}{ }^{1} \mathrm{H} \mathrm{NMR}(400 \mathrm{MHz})$ of $4 \mathbf{e d}$ in $\mathrm{CDCl}_{3}$

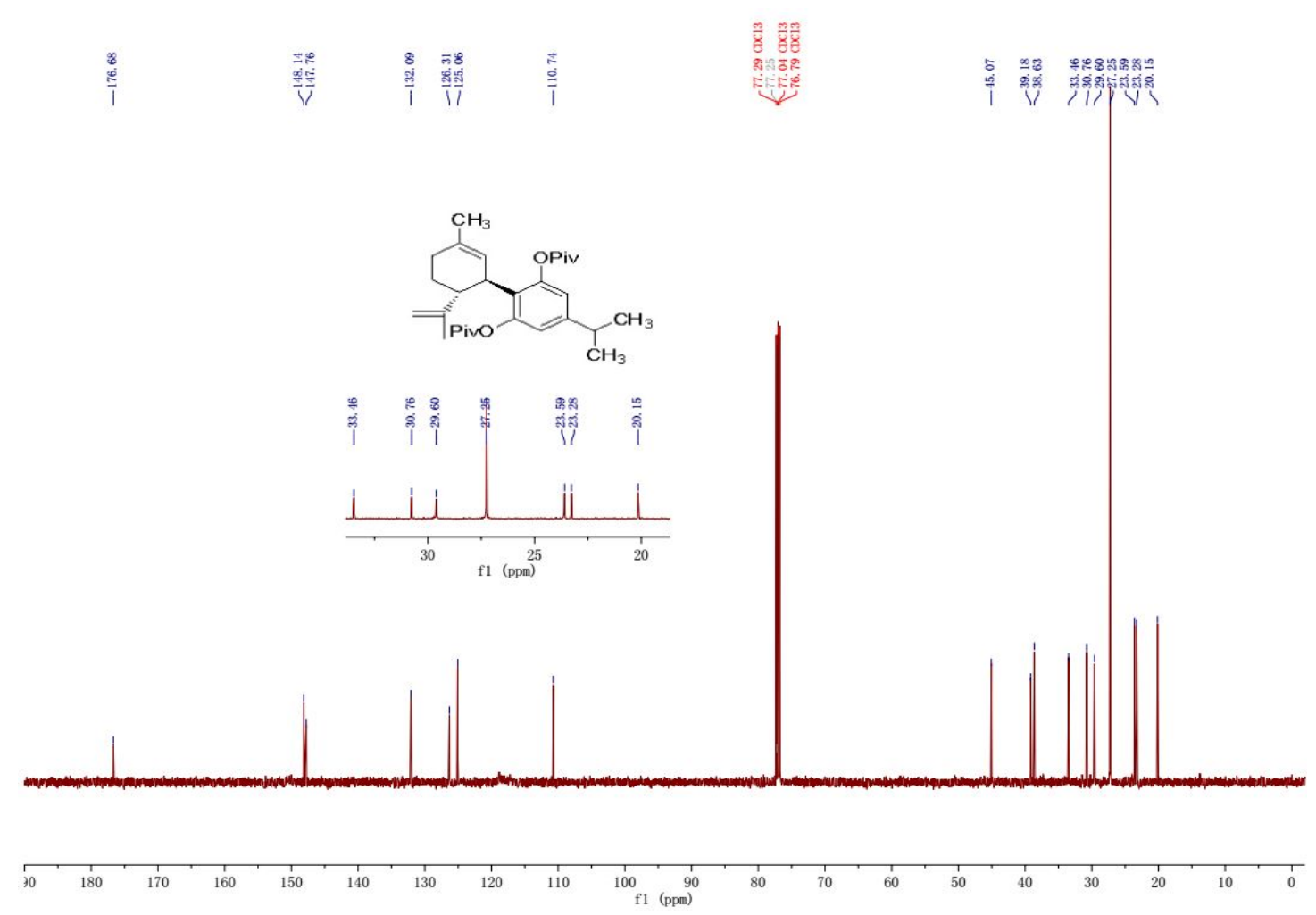

Figure $\mathbf{S 3 6}{ }^{13} \mathrm{C}\left\{{ }^{1} \mathrm{H}\right\} \mathrm{NMR}(125 \mathrm{MHz})$ of $\mathbf{4 e d}$ in $\mathrm{CDCl}_{3}$ 


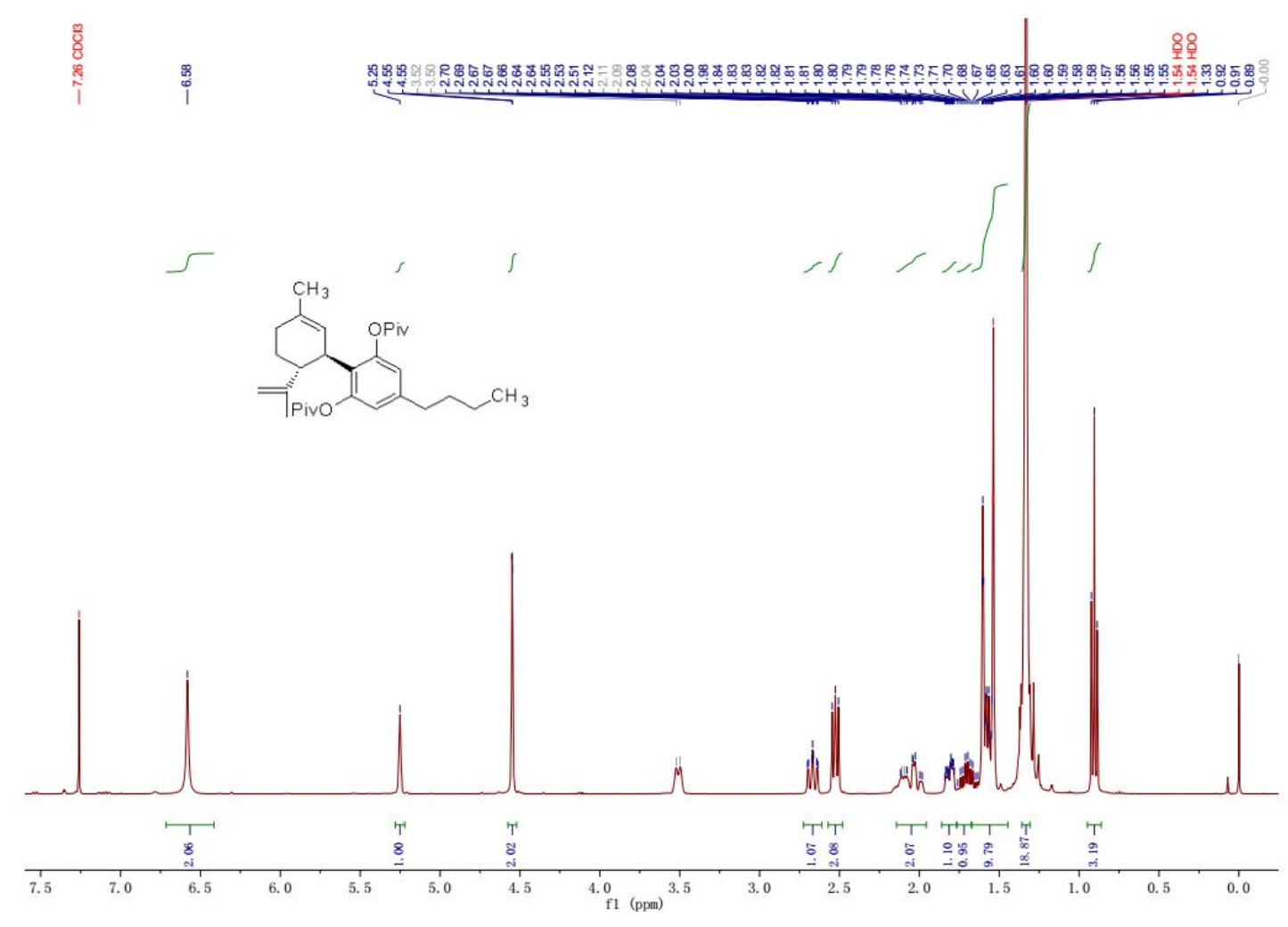

Figure $\mathbf{S 3 7}{ }^{1} \mathrm{H}$ NMR(400 MHz) of 4ee in $\mathrm{CDCl}_{3}$
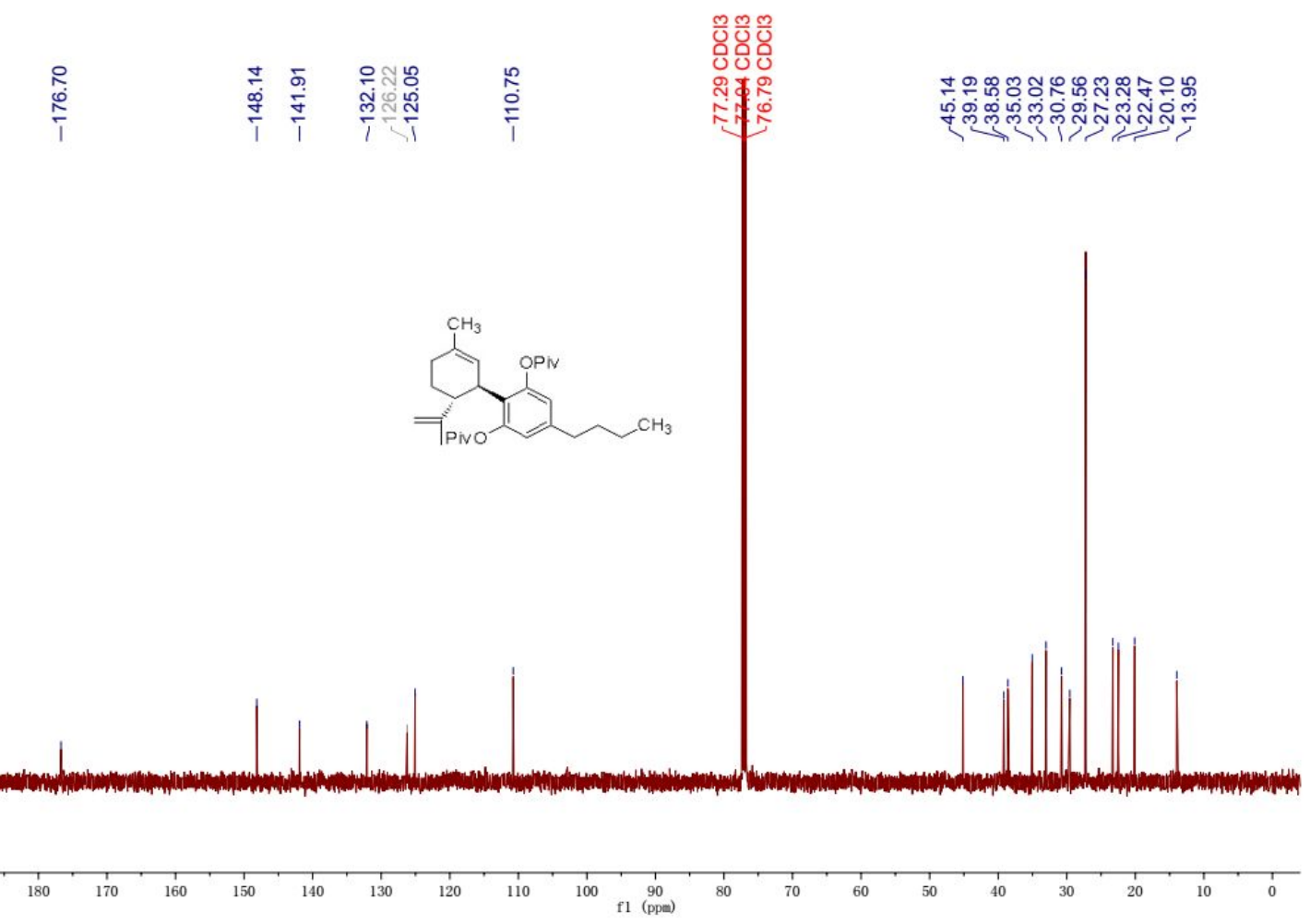

Figure $\mathbf{S 3 8}{ }^{13} \mathrm{C}\left\{{ }^{1} \mathrm{H}\right\} \mathrm{NMR}(125 \mathrm{MHz})$ of 4 ee in $\mathrm{CDCl}_{3}$ 


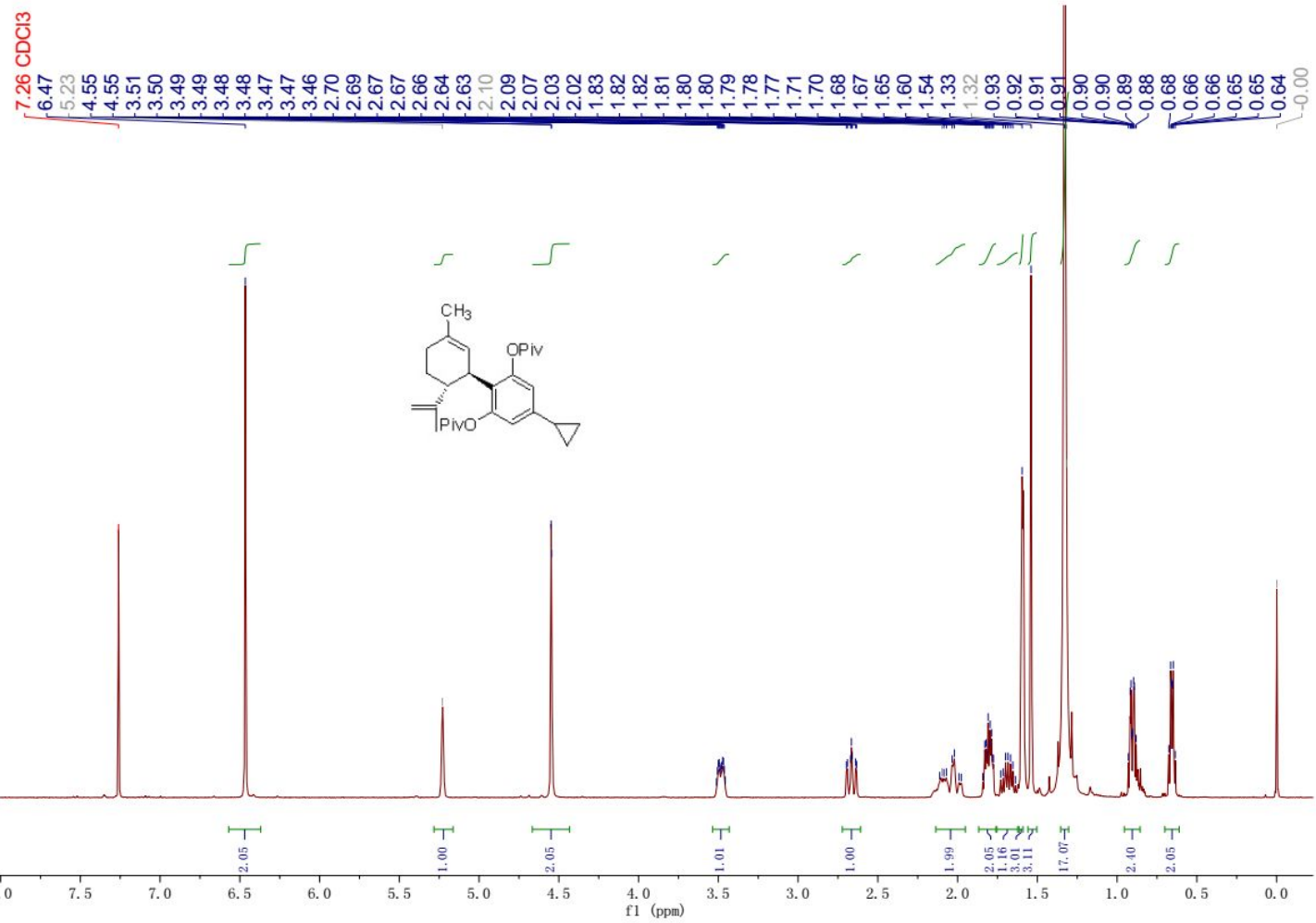

Figure $\mathbf{S 3 9}{ }^{1} \mathrm{H}$ NMR(400 MHz) of 4 ef in $\mathrm{CDCl}_{3}$
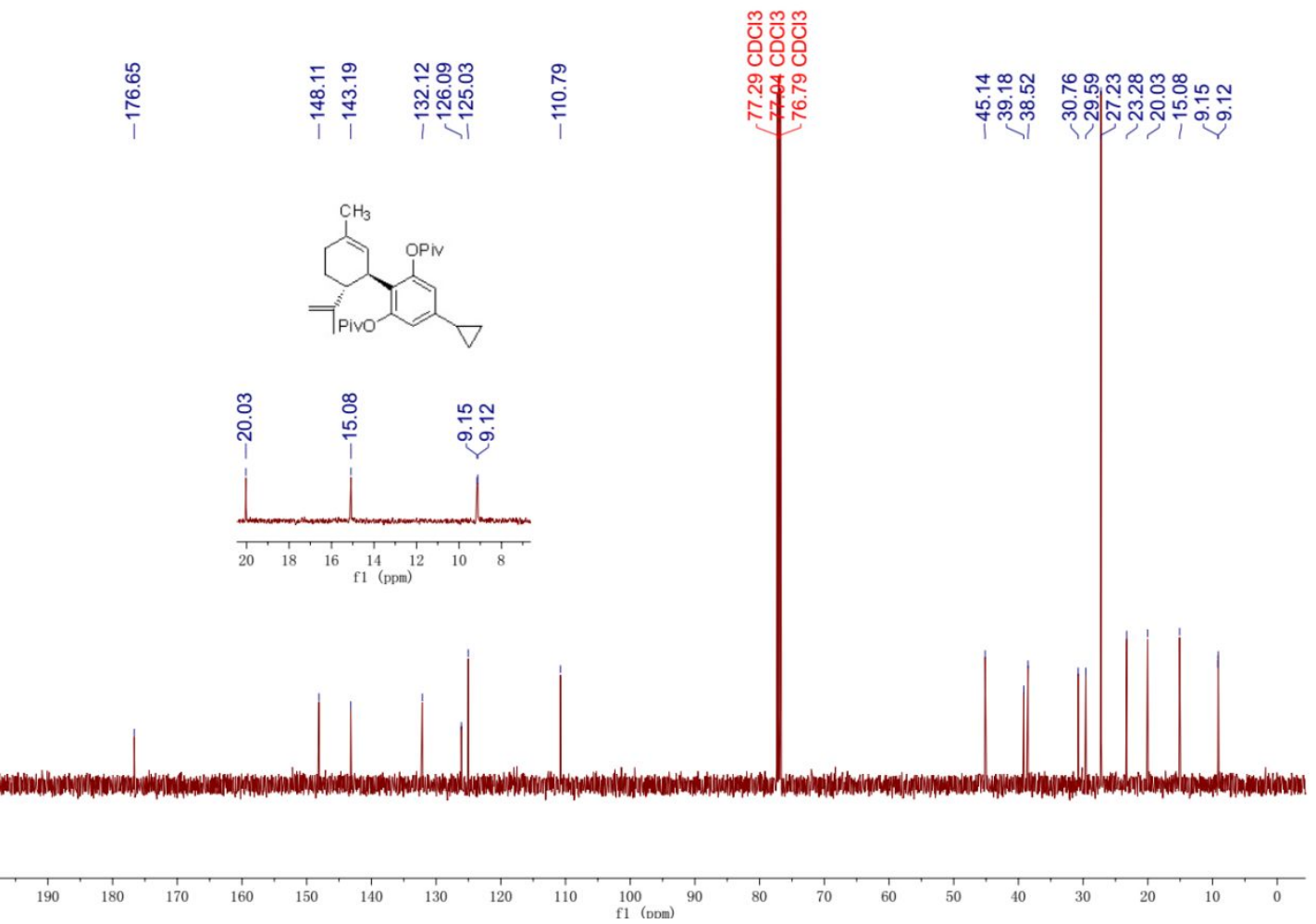

Figure $\mathbf{S 4 0}{ }^{13} \mathrm{C}\left\{{ }^{1} \mathrm{H}\right\} \mathrm{NMR}(125 \mathrm{MHz})$ of $\mathbf{4 e f}$ in $\mathrm{CDCl}_{3}$ 


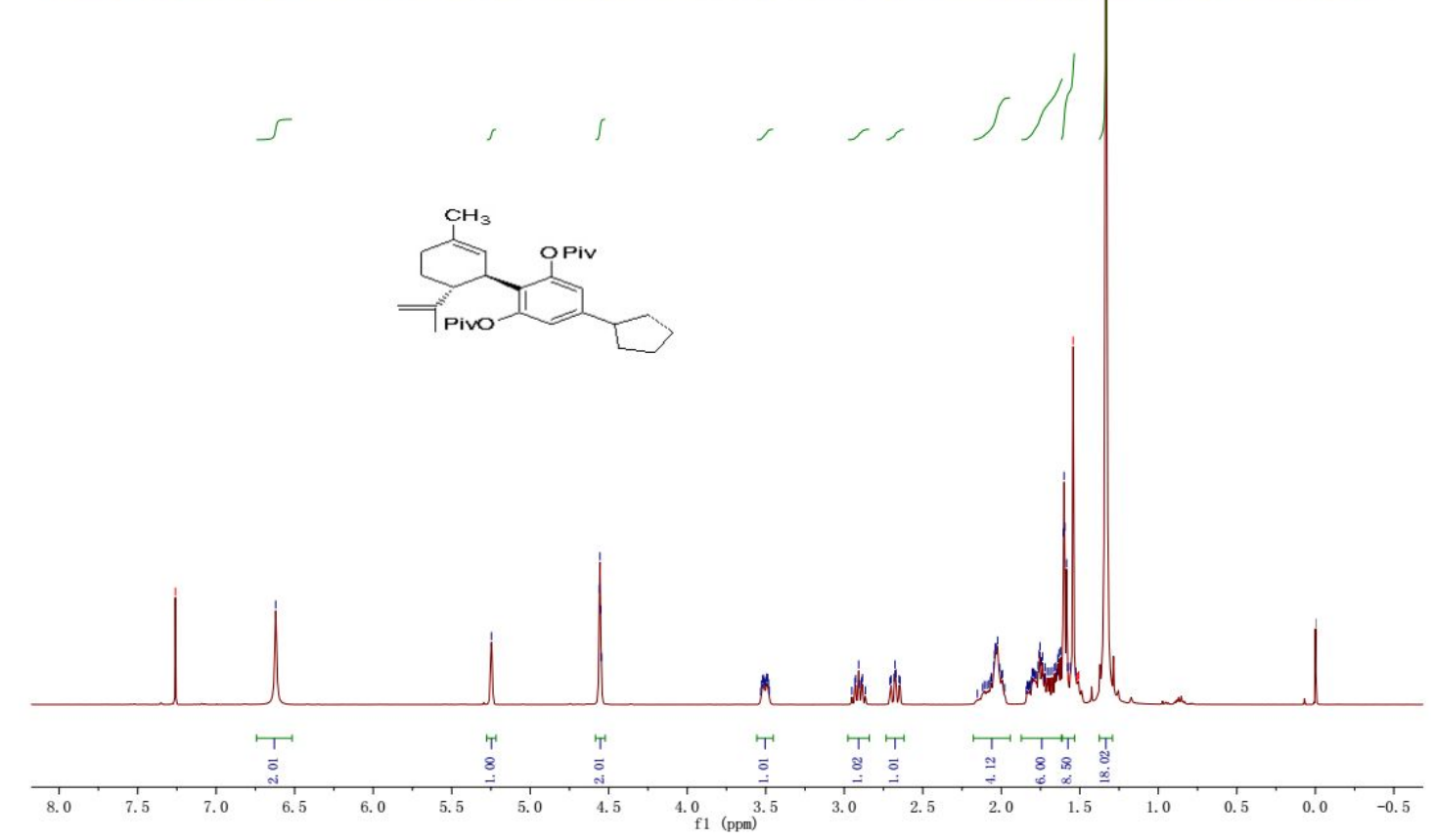

Figure $\mathbf{S 4 1}{ }^{1} \mathrm{H}$ NMR(400 MHz) of 4 eg in $\mathrm{CDCl}_{3}$

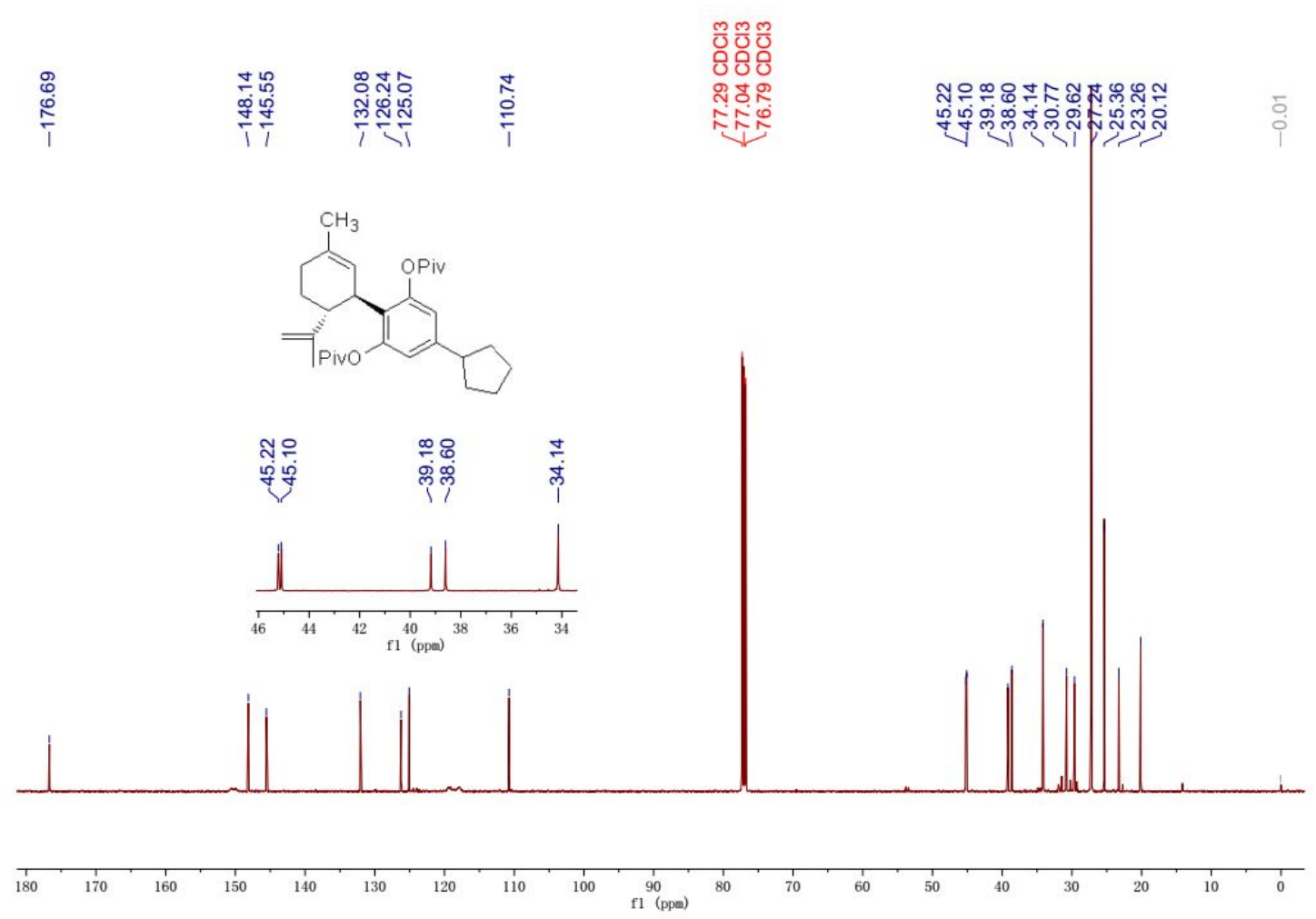

Figure $\mathbf{S 4 2}{ }^{13} \mathrm{C}\left\{{ }^{1} \mathrm{H}\right\} \mathrm{NMR}(125 \mathrm{MHz})$ of 4 eg in $\mathrm{CDCl}_{3}$ 
응

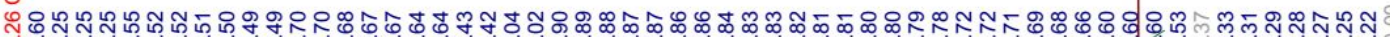

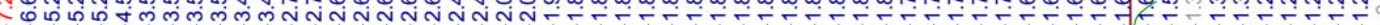<smiles>CCCC1=C[C@@H](c2c(O)cc(C3CCCCC3)cc2OC(=O)O)[C@H](C(C)(C)C)CC1</smiles>

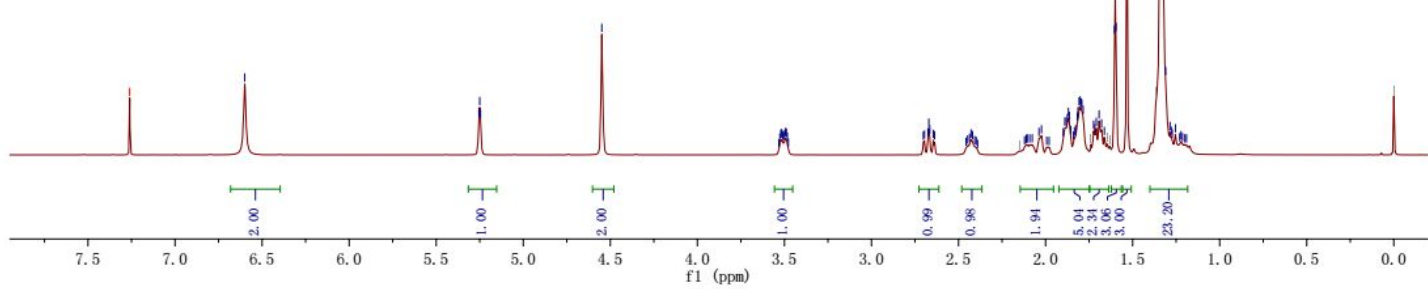

Figure $\mathbf{S 4 3}{ }^{1} \mathrm{H}$ NMR(400 MHz) of $4 \mathbf{e h}$ in $\mathrm{CDCl}_{3}$

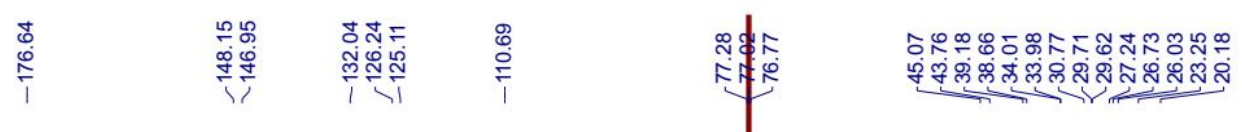

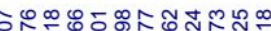

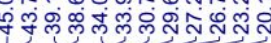
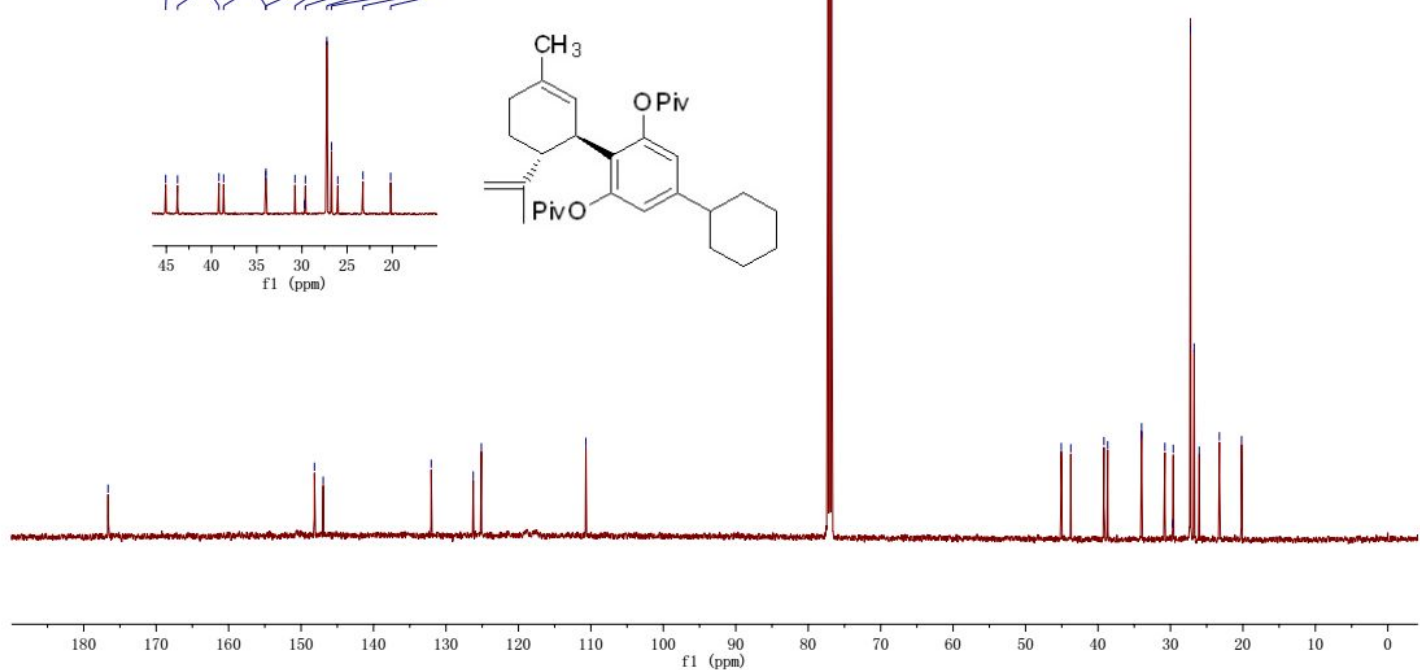

Figure $\mathbf{S 4 4}{ }^{13} \mathrm{C}\left\{{ }^{1} \mathrm{H}\right\}$ NMR $(125 \mathrm{MHz})$ of $\mathbf{4 e h}$ in $\mathrm{CDCl}_{3}$ 


\section{范}

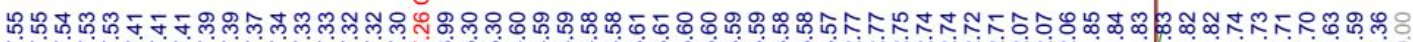

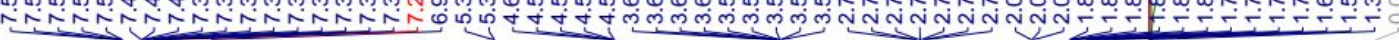

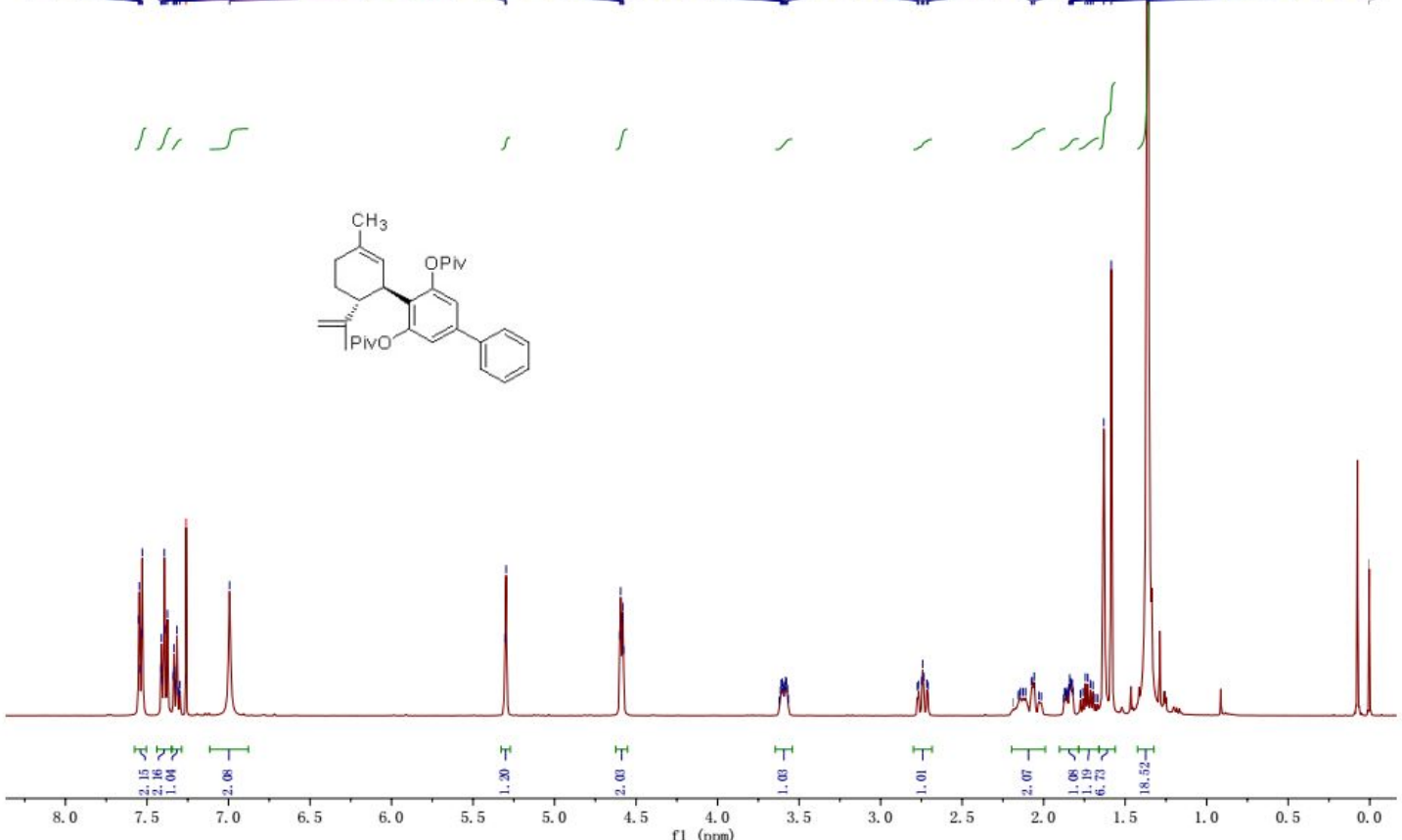

Figure $\mathbf{S 4 5}{ }^{1} \mathrm{H}$ NMR(400 MHz) of 4 ei in $\mathrm{CDCl}_{3}$
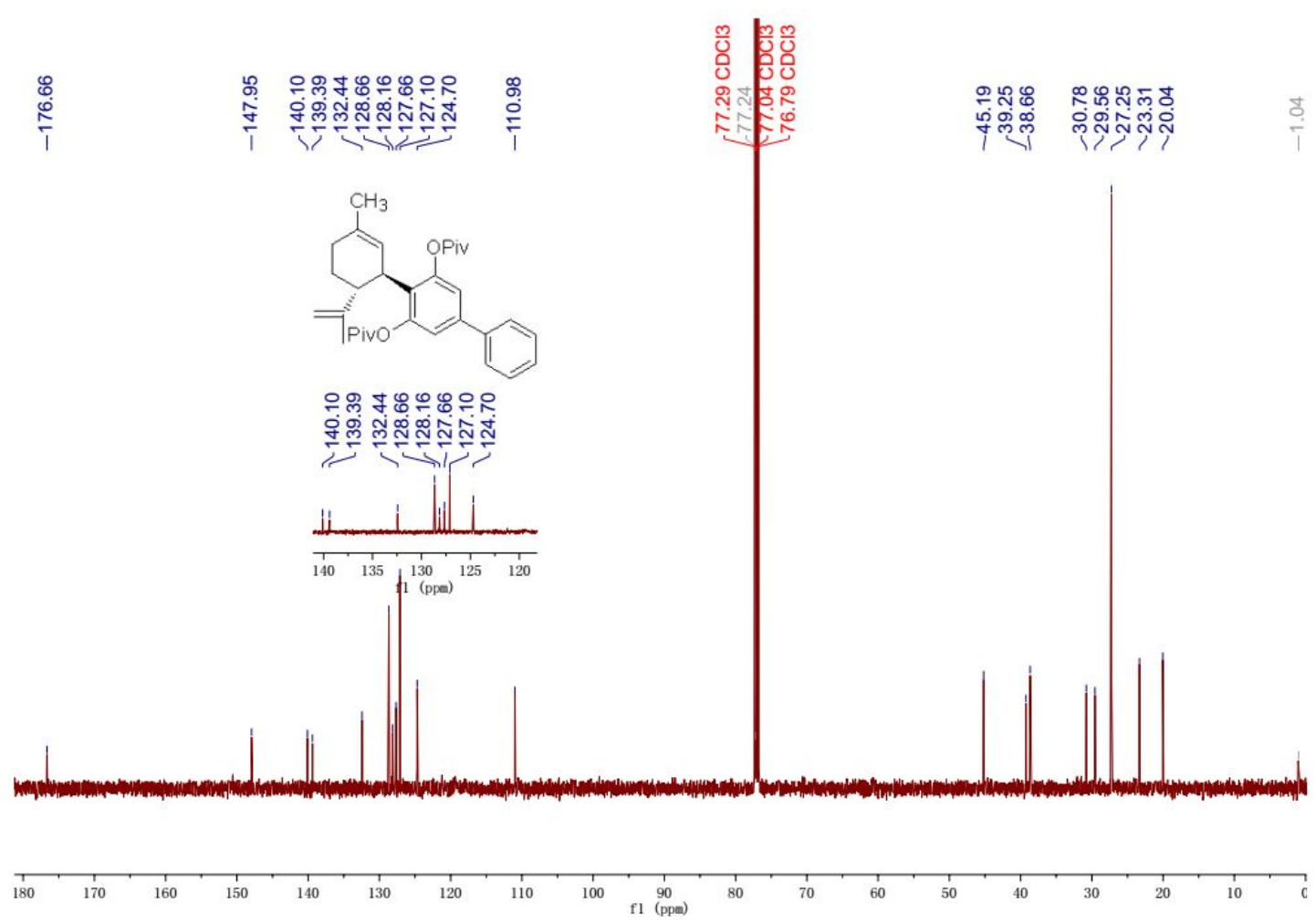

Figure $\mathbf{S 4 6}{ }^{13} \mathrm{C}\left\{{ }^{1} \mathrm{H}\right\} \mathrm{NMR}(125 \mathrm{MHz})$ of 4 ei in $\mathrm{CDCl}_{3}$ 


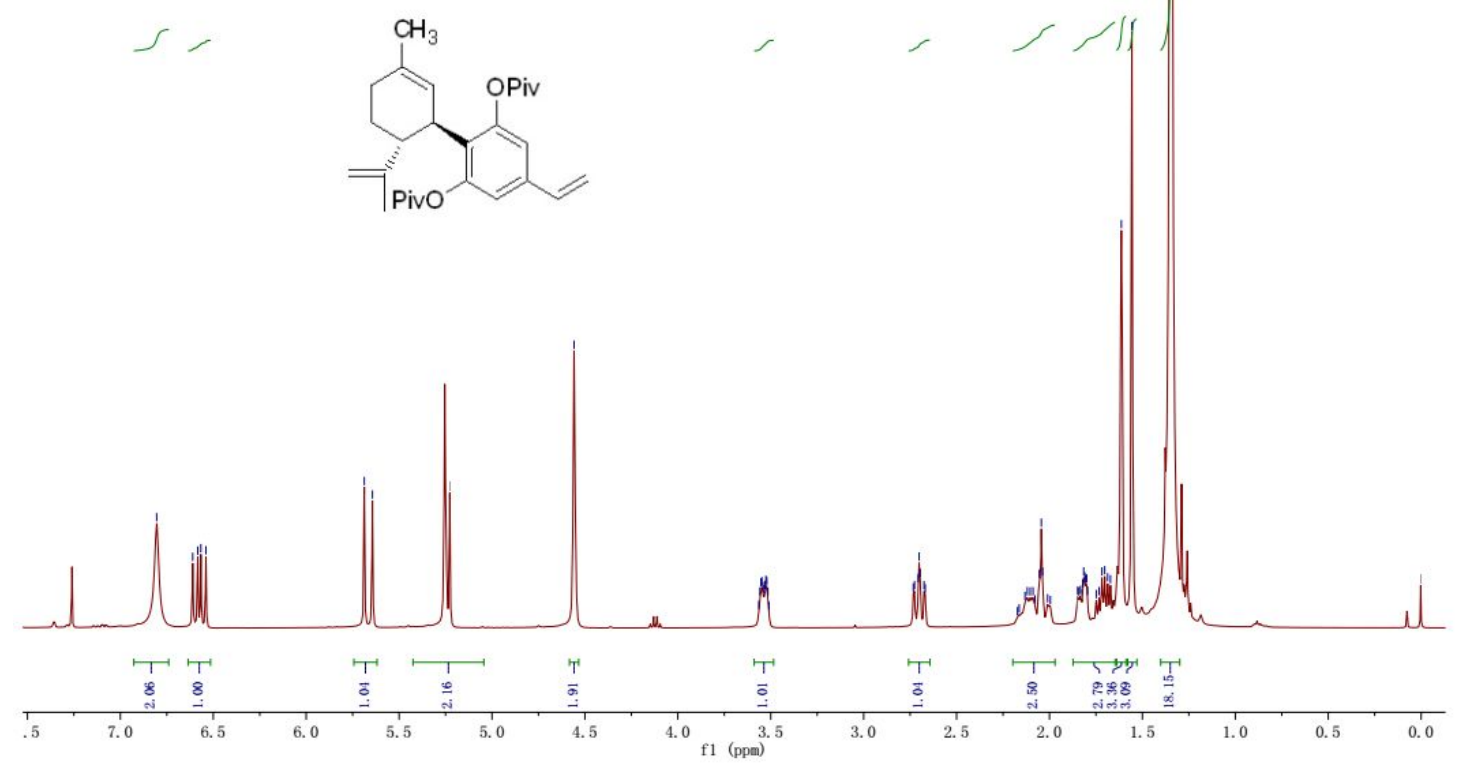

Figure $\mathbf{S 4 7}{ }^{1} \mathrm{H} \mathrm{NMR}(400 \mathrm{MHz})$ of $\mathbf{4 e j}$ in $\mathrm{CDCl}_{3}$
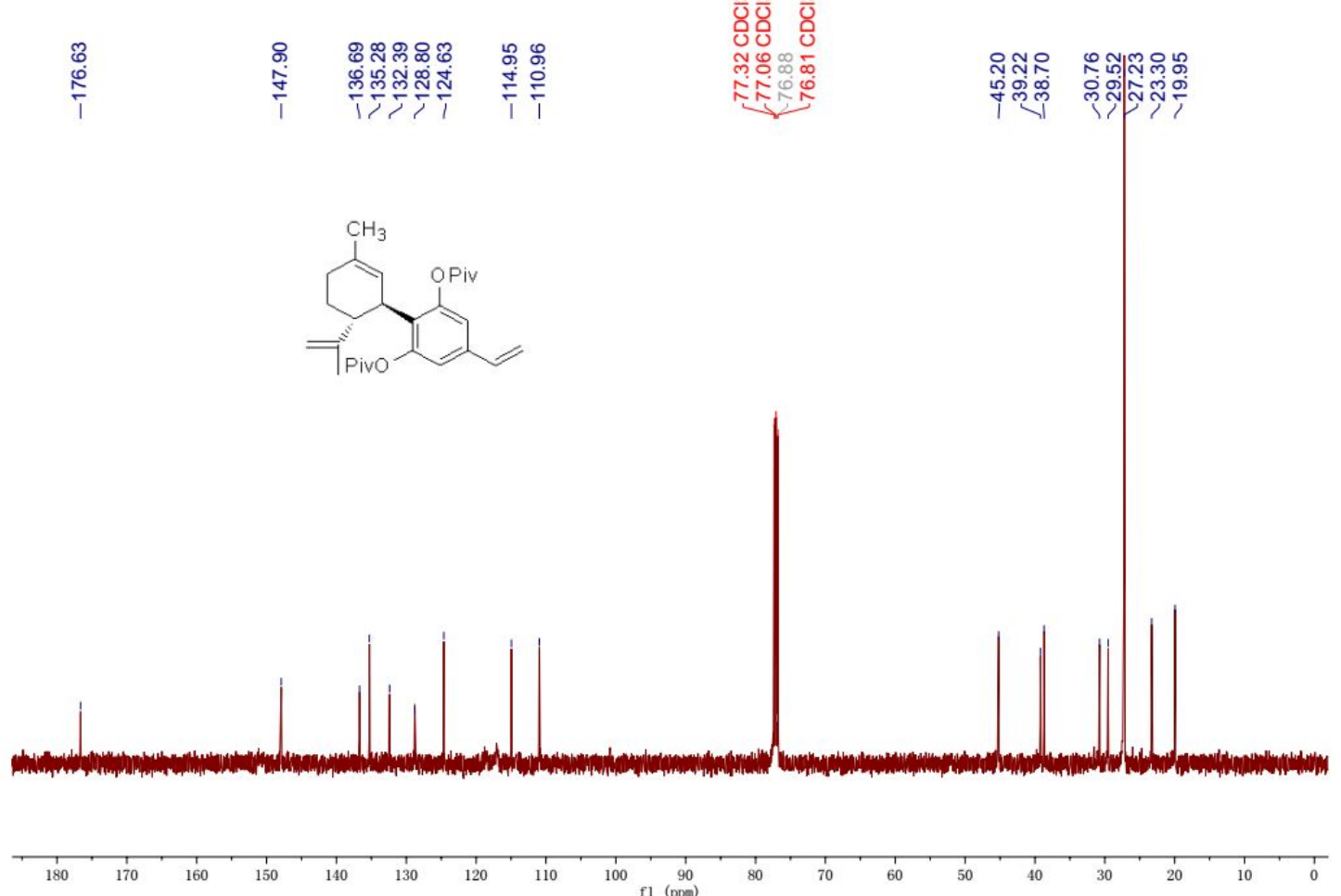

Figure $\mathbf{S 4 8}{ }^{13} \mathrm{C}\left\{{ }^{1} \mathrm{H}\right\}$ NMR $(125 \mathrm{MHz})$ of $4 \mathbf{e j}$ in $\mathrm{CDCl}_{3}$ 


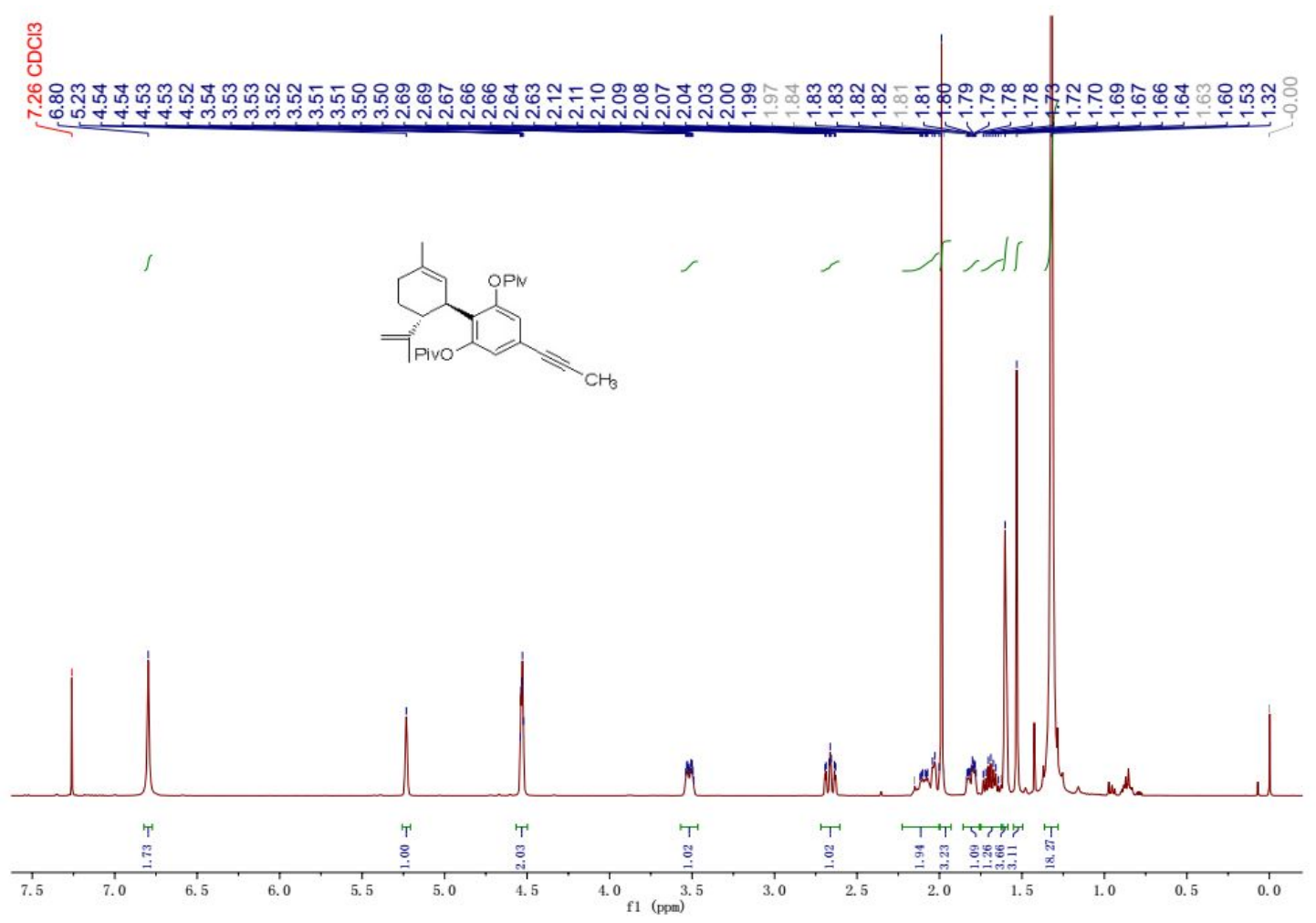

Figure S49 ${ }^{1} \mathrm{H}$ NMR(400 MHz) of 4 ek in $\mathrm{CDCl}_{3}$

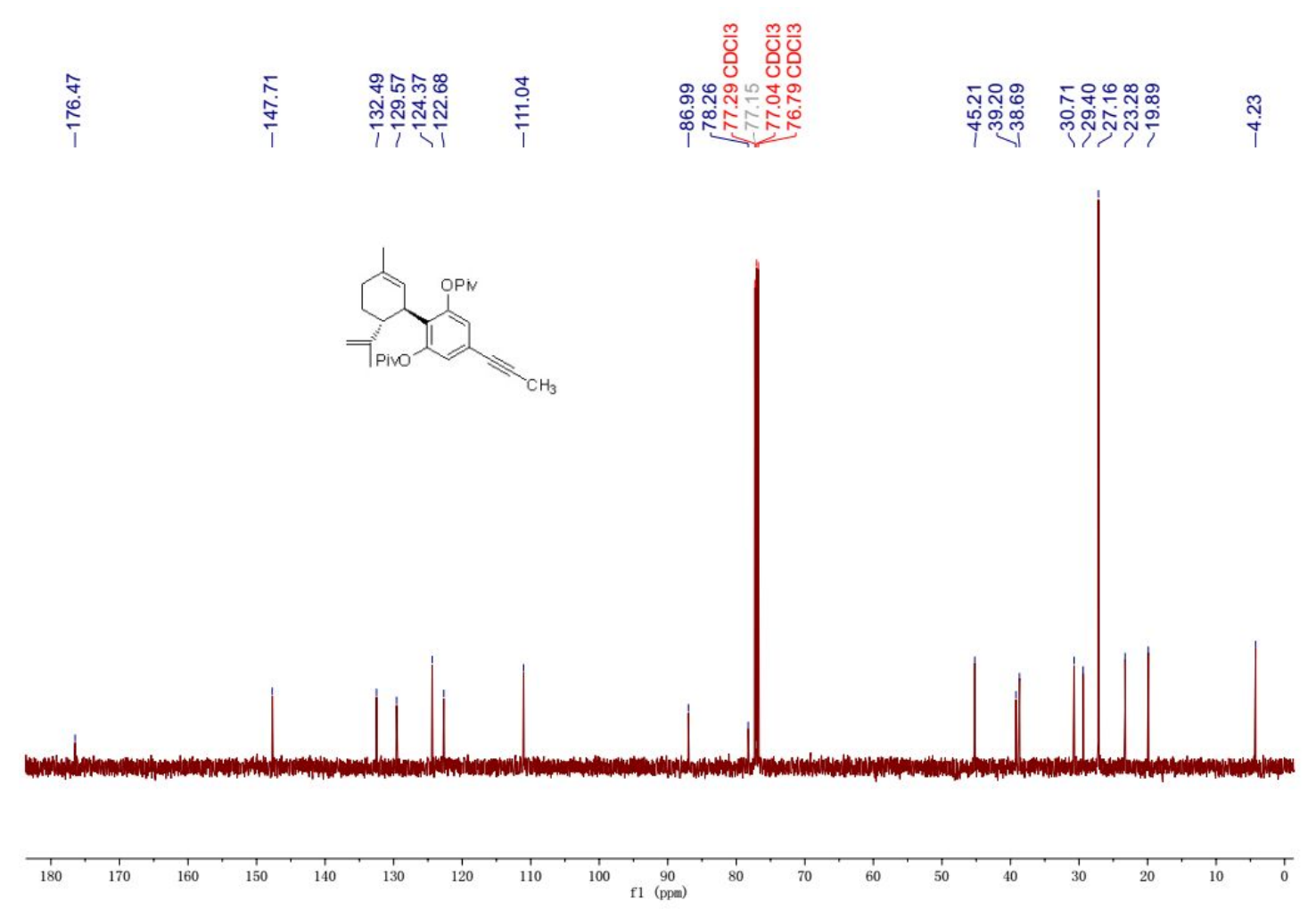

Figure S50 ${ }^{13} \mathrm{C}\left\{{ }^{1} \mathrm{H}\right\} \mathrm{NMR}(125 \mathrm{MHz})$ of $4 \mathbf{e k}$ in $\mathrm{CDCl}_{3}$ 

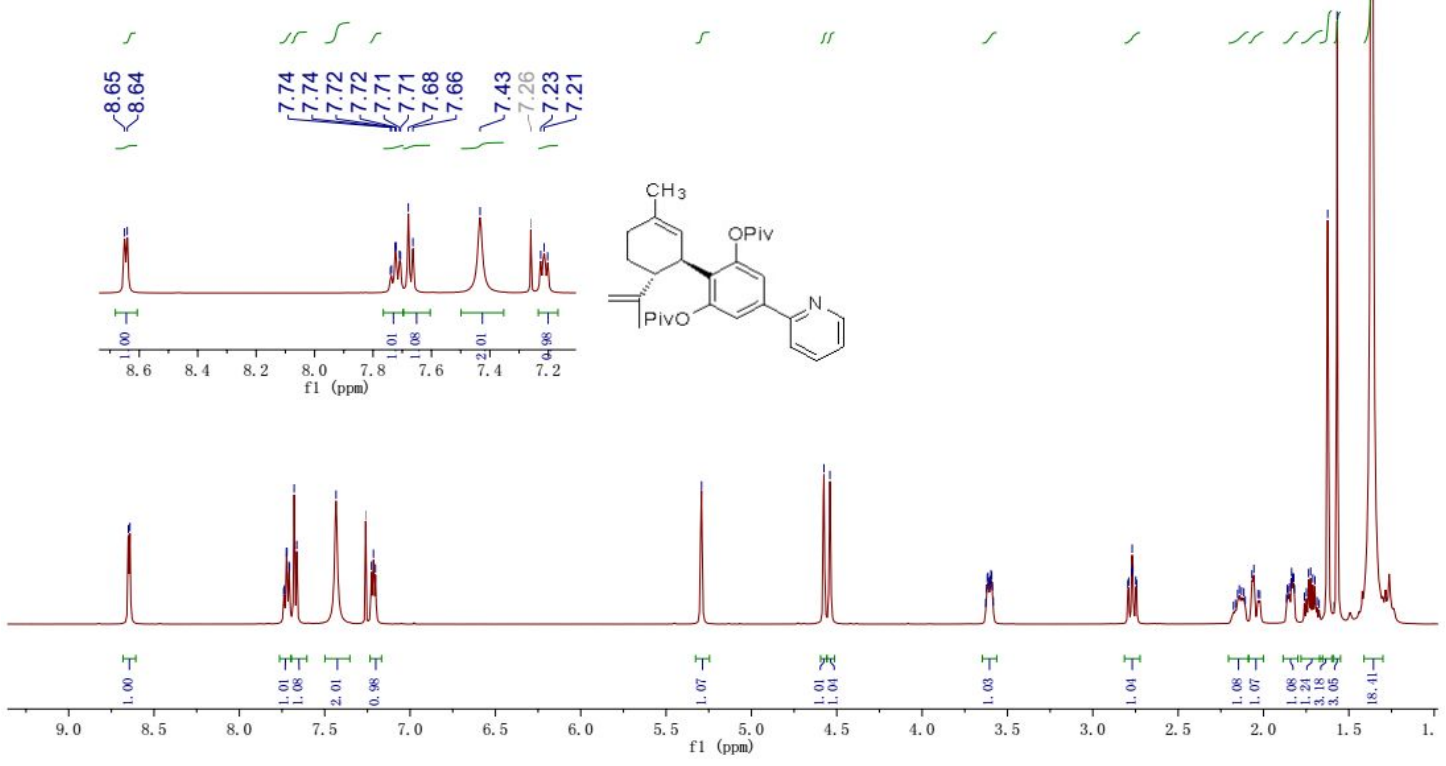

Figure $\mathbf{S 5 1}{ }^{1} \mathrm{H}$ NMR(400 MHz) of $4 \mathbf{e l}$ in $\mathrm{CDCl}_{3}$

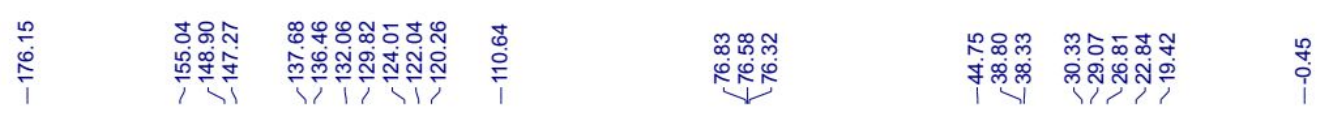
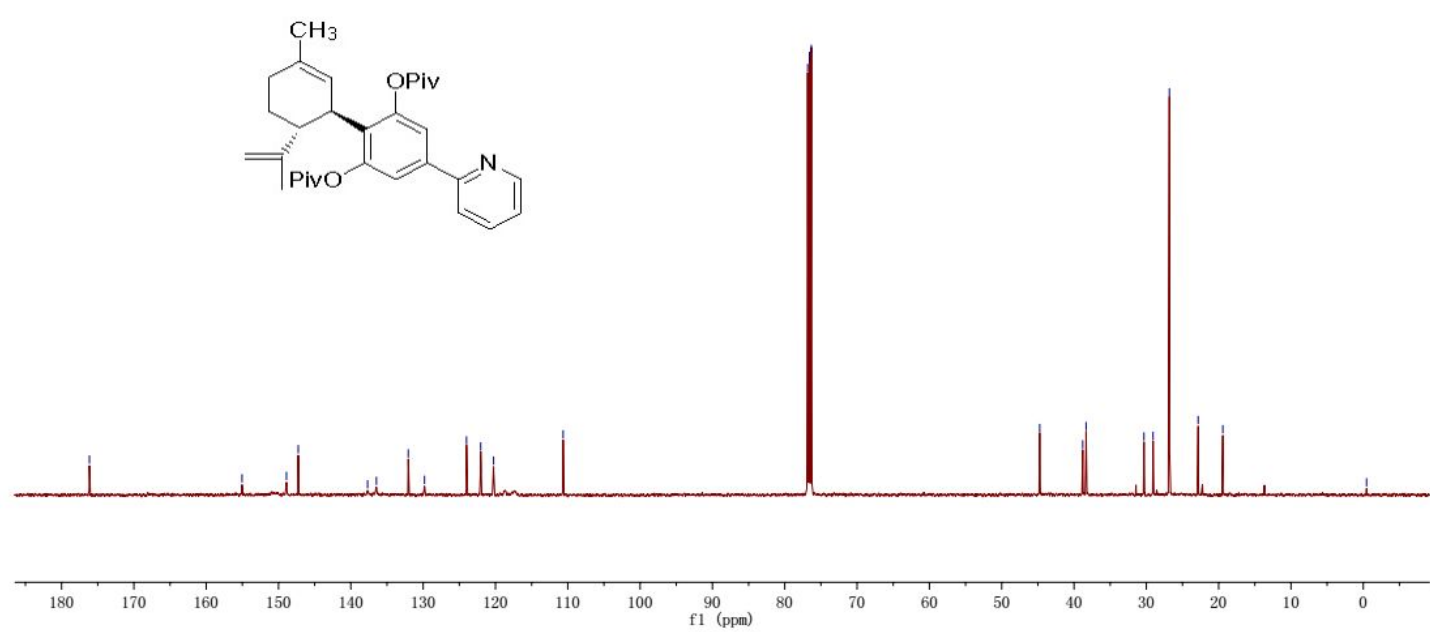

Figure $\mathbf{S 5 2}$ and ${ }^{13} \mathrm{C}\left\{{ }^{1} \mathrm{H}\right\} \mathrm{NMR}(125 \mathrm{MHz})$ of $4 \mathbf{e l}$ in $\mathrm{CDCl}_{3}$ 


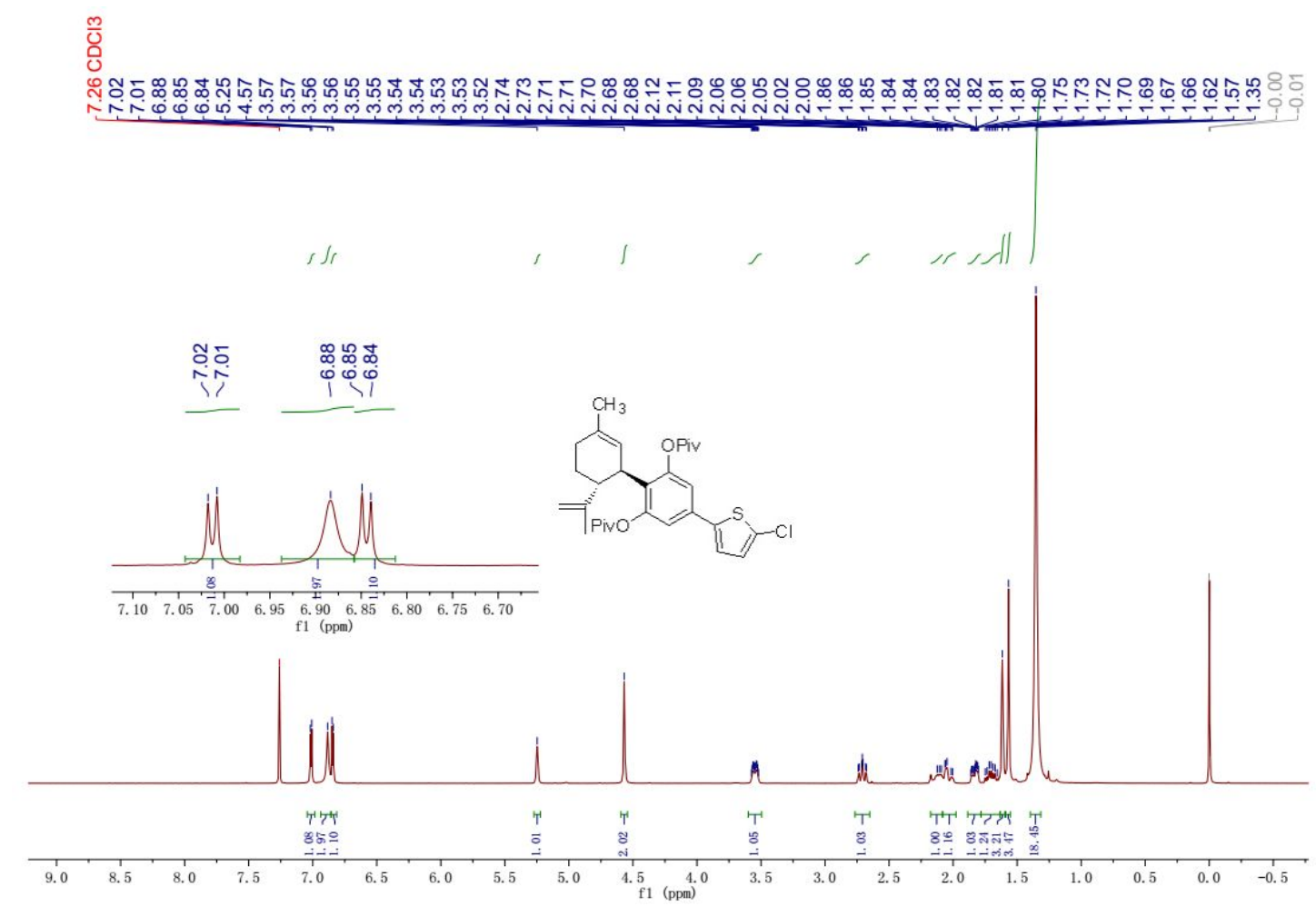

Figure S53 ${ }^{1} \mathrm{H}$ NMR(400 MHz) of $4 \mathbf{e m}$ in $\mathrm{CDCl}_{3}$

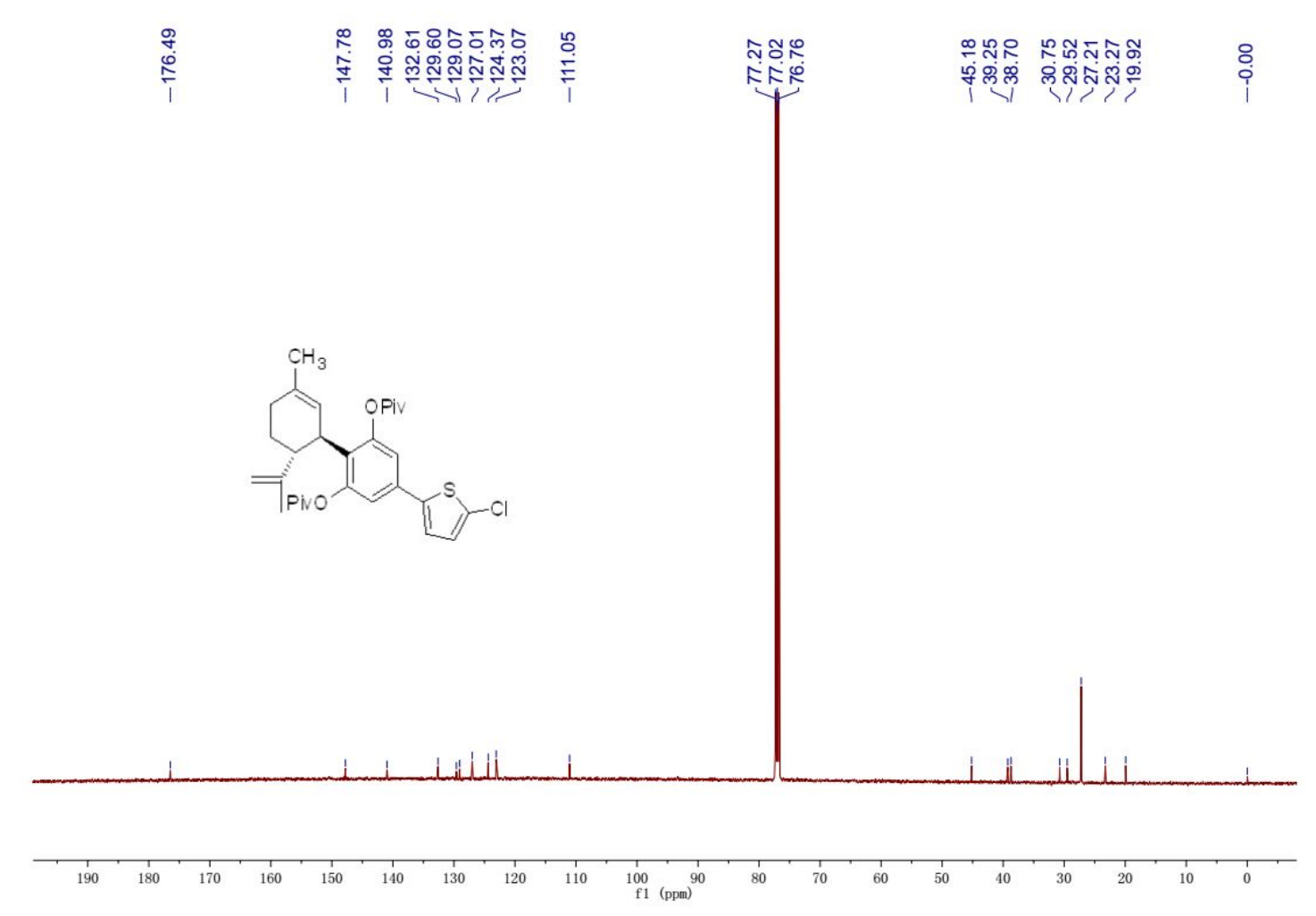

Figure S54 and ${ }^{13} \mathrm{C}\left\{{ }^{1} \mathrm{H}\right\} \mathrm{NMR}(125 \mathrm{MHz})$ of $4 \mathbf{e m}$ in $\mathrm{CDCl}_{3}$ 


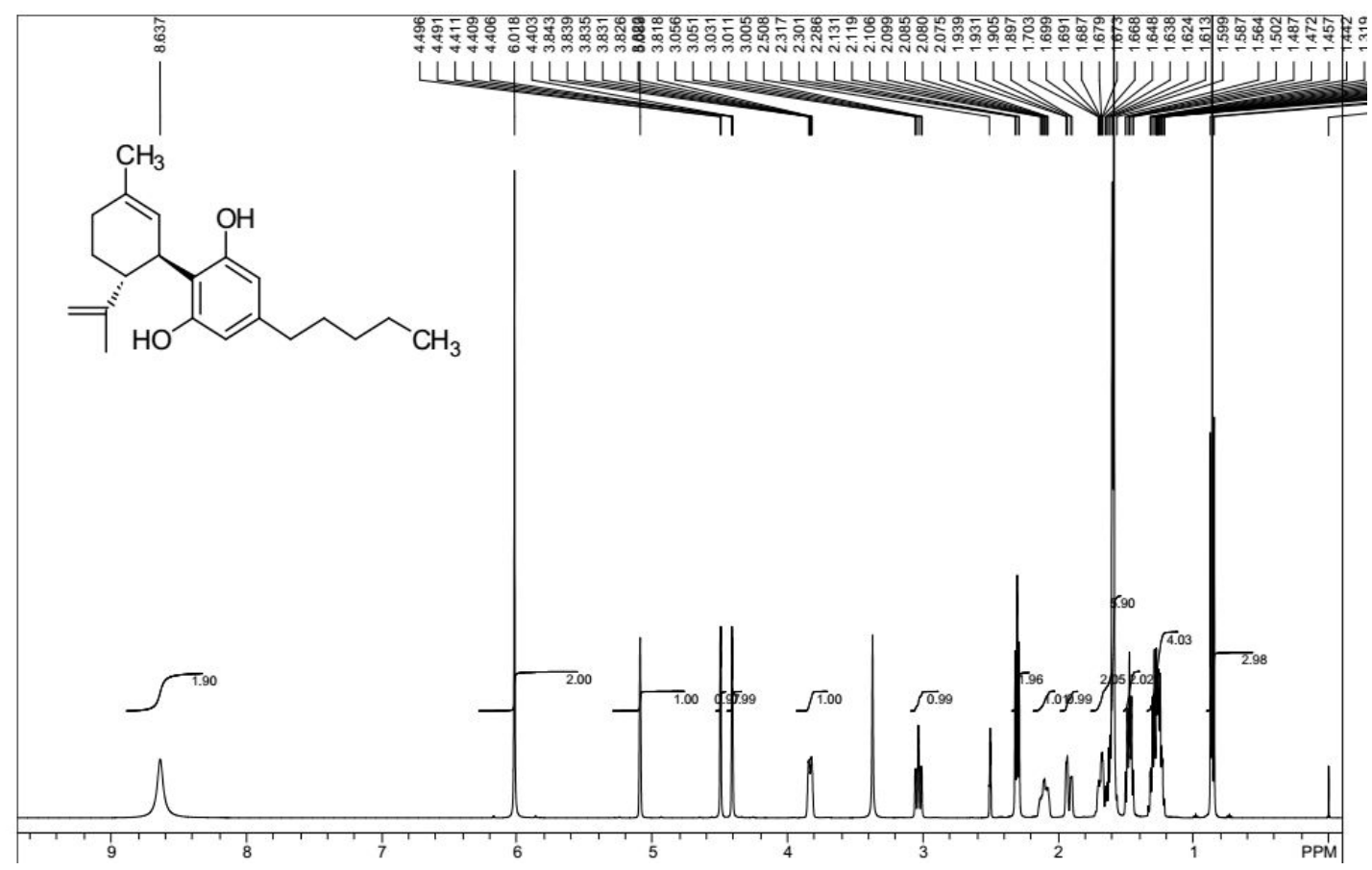

Figure S55 ${ }^{1} \mathrm{H}$ NMR(400 MHz) of CBD in DMSO- $d_{6}$

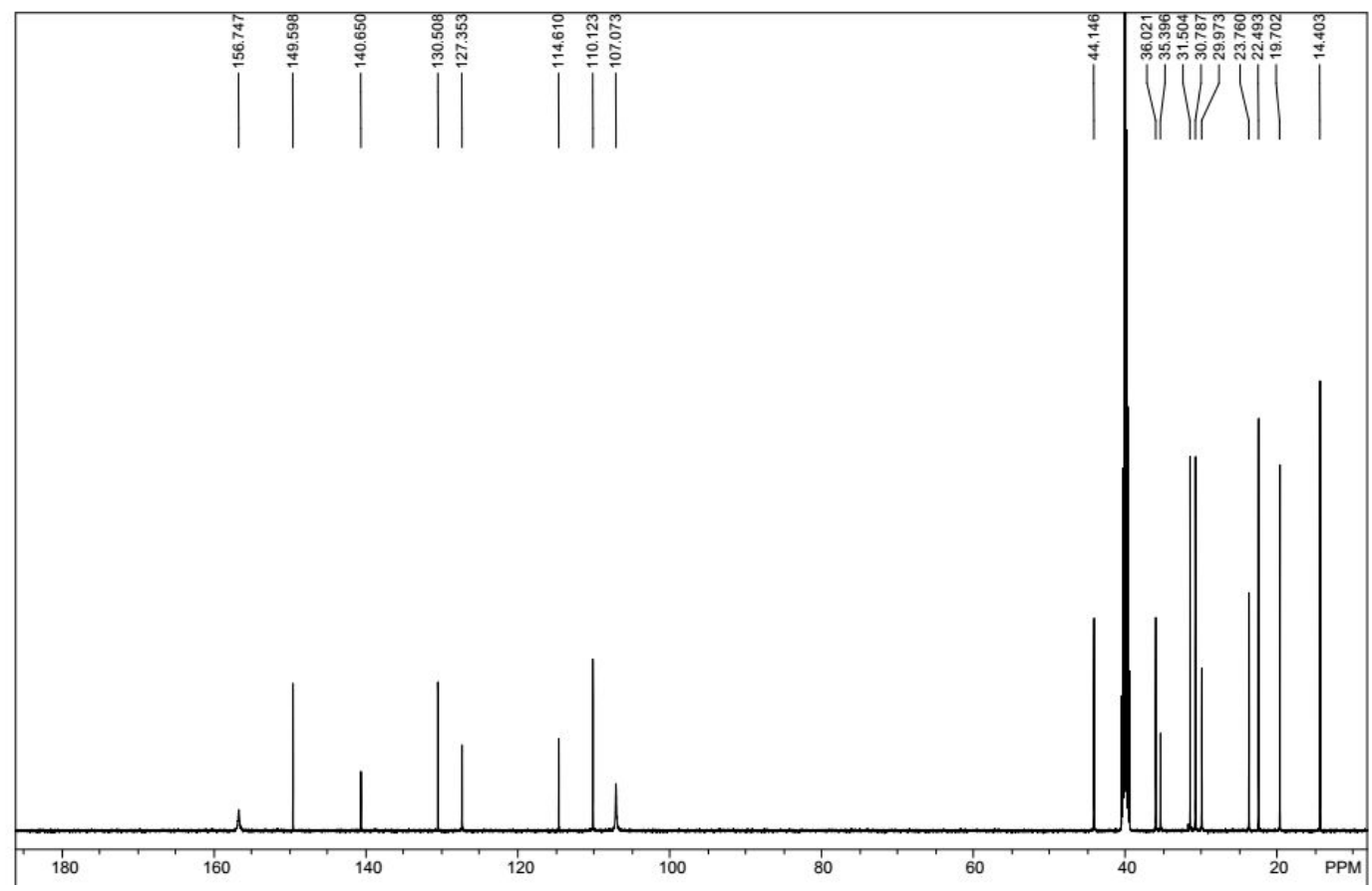

Figure S56 ${ }^{13} \mathrm{C}\left\{{ }^{1} \mathrm{H}\right\} \mathrm{NMR}(125 \mathrm{MHz})$ of CBD in DMSO- $d_{6}$ 


\section{$\int$}

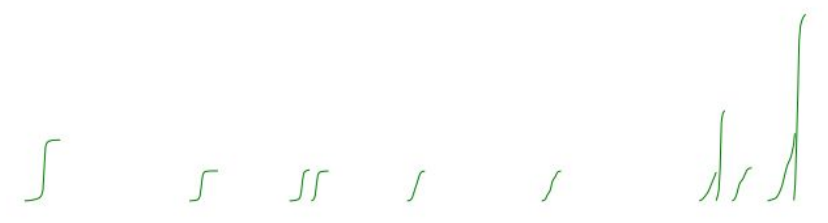<smiles>C=C(C)C1CCC(C)=C[C@H]1c1c(O)cc(C)cc1O</smiles>
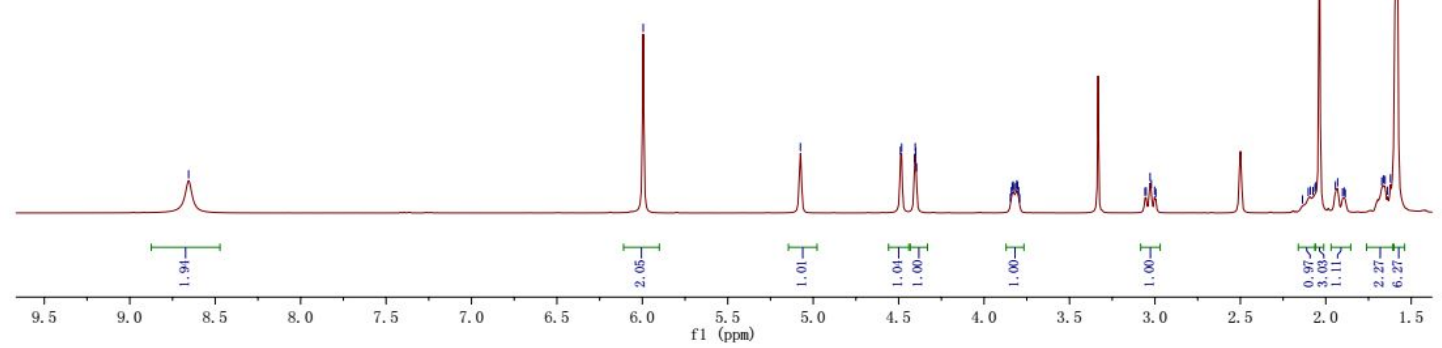

Figure S57 ${ }^{1} \mathrm{H}$ NMR(400 MHz) of $\mathbf{6 b}$ in DMSO- $d_{6}$

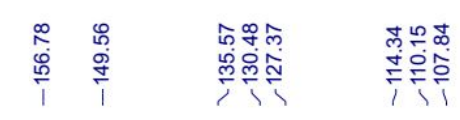

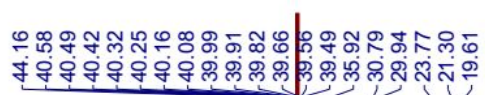<smiles>C=C(C)[C@@H]1CCC(C)=C[C@H]1c1c(O)cc(C)cc1O</smiles>
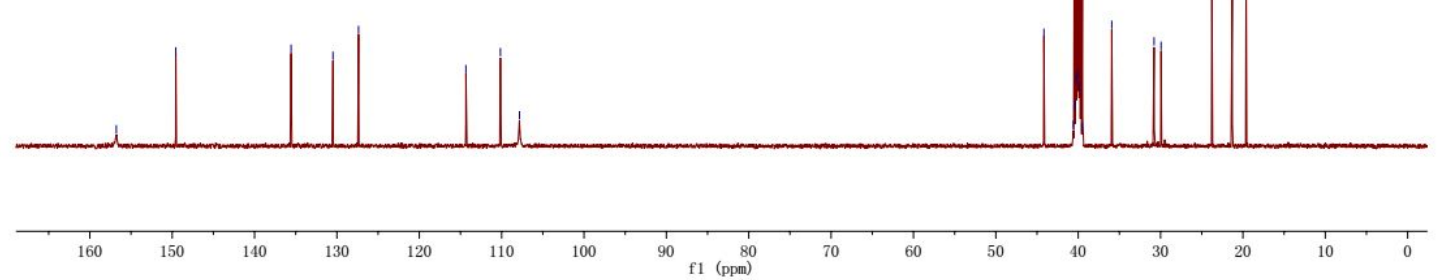

Figure $\mathbf{S 5 8}{ }^{13} \mathrm{C}\left\{{ }^{1} \mathrm{H}\right\} \mathrm{NMR}(125 \mathrm{MHz})$ of $\mathbf{6 b}$ in DMSO- $d_{6}$ 


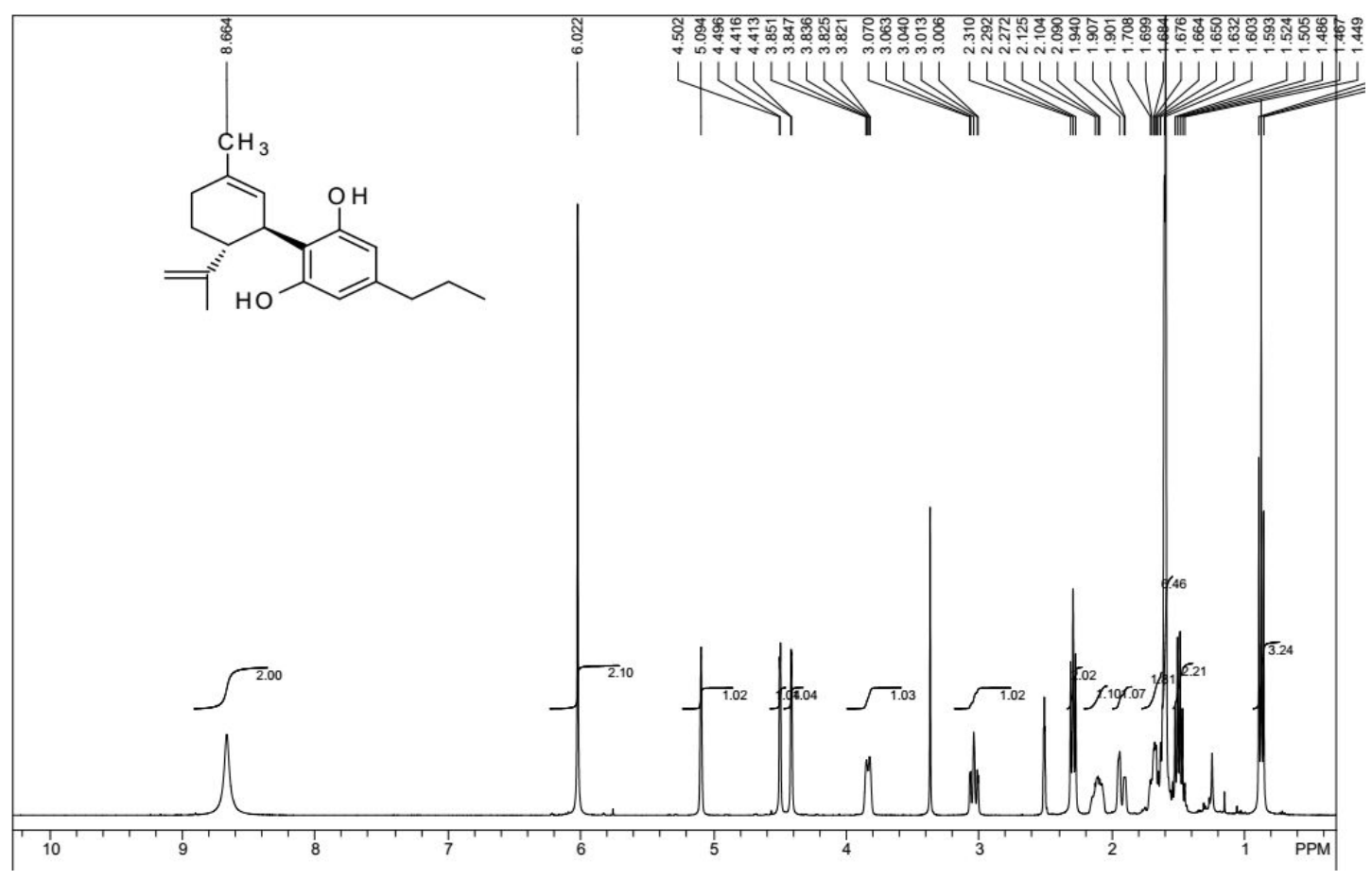

Figure S59 ${ }^{1} \mathrm{H}$ NMR(400 MHz) of $\mathbf{6 c}$ in DMSO- $d_{6}$

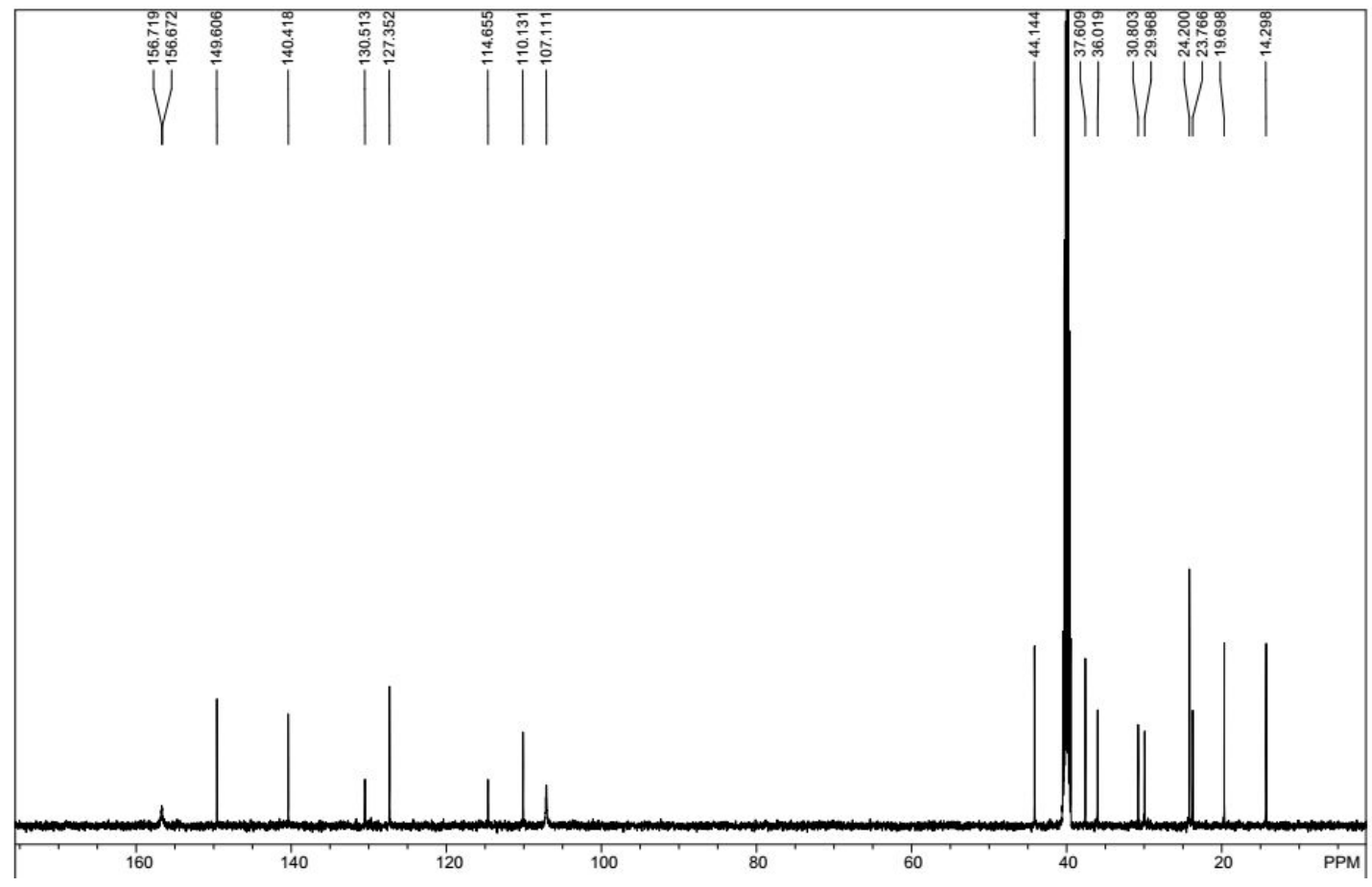

Figure $\mathbf{S 6 0}{ }^{13} \mathrm{C}\left\{{ }^{1} \mathrm{H}\right\} \mathrm{NMR}(125 \mathrm{MHz})$ of $\mathbf{6 c}$ in DMSO- $d_{6}$ 


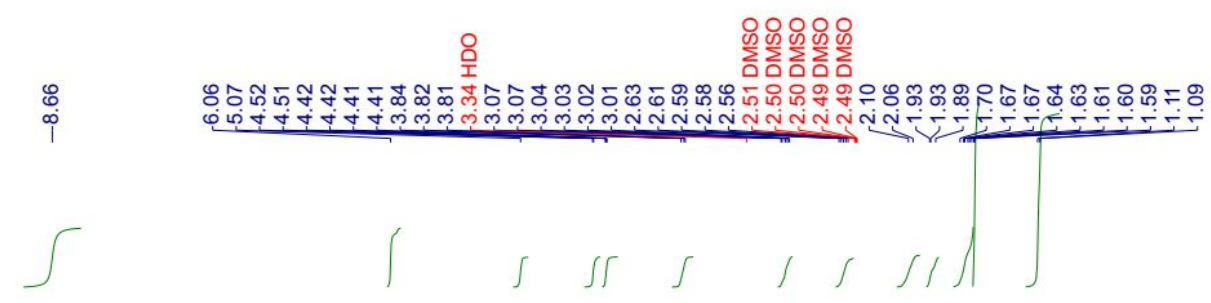<smiles>C=C(C)C1CCC(C)=CC1c1c(O)cc(C(C)C)cc1O</smiles>

Figure S61 ${ }^{1} \mathrm{H}$ NMR(400 MHz) of $\mathbf{6 d}$ in DMSO- $d_{6}$

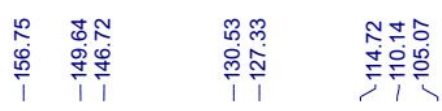
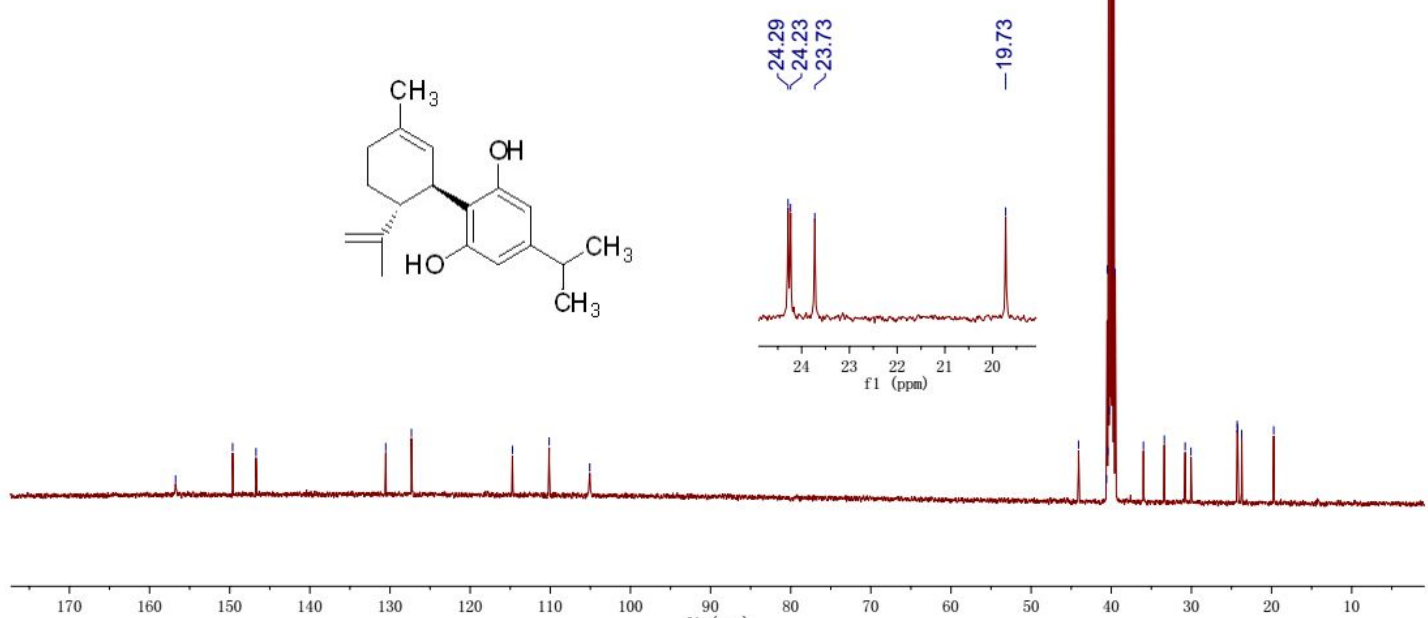

Figure $\mathbf{S 6 2}{ }^{13} \mathrm{C}\left\{{ }^{1} \mathrm{H}\right\}$ NMR $(125 \mathrm{MHz})$ of $\mathbf{6 d}$ in DMSO- $d_{6}$ 


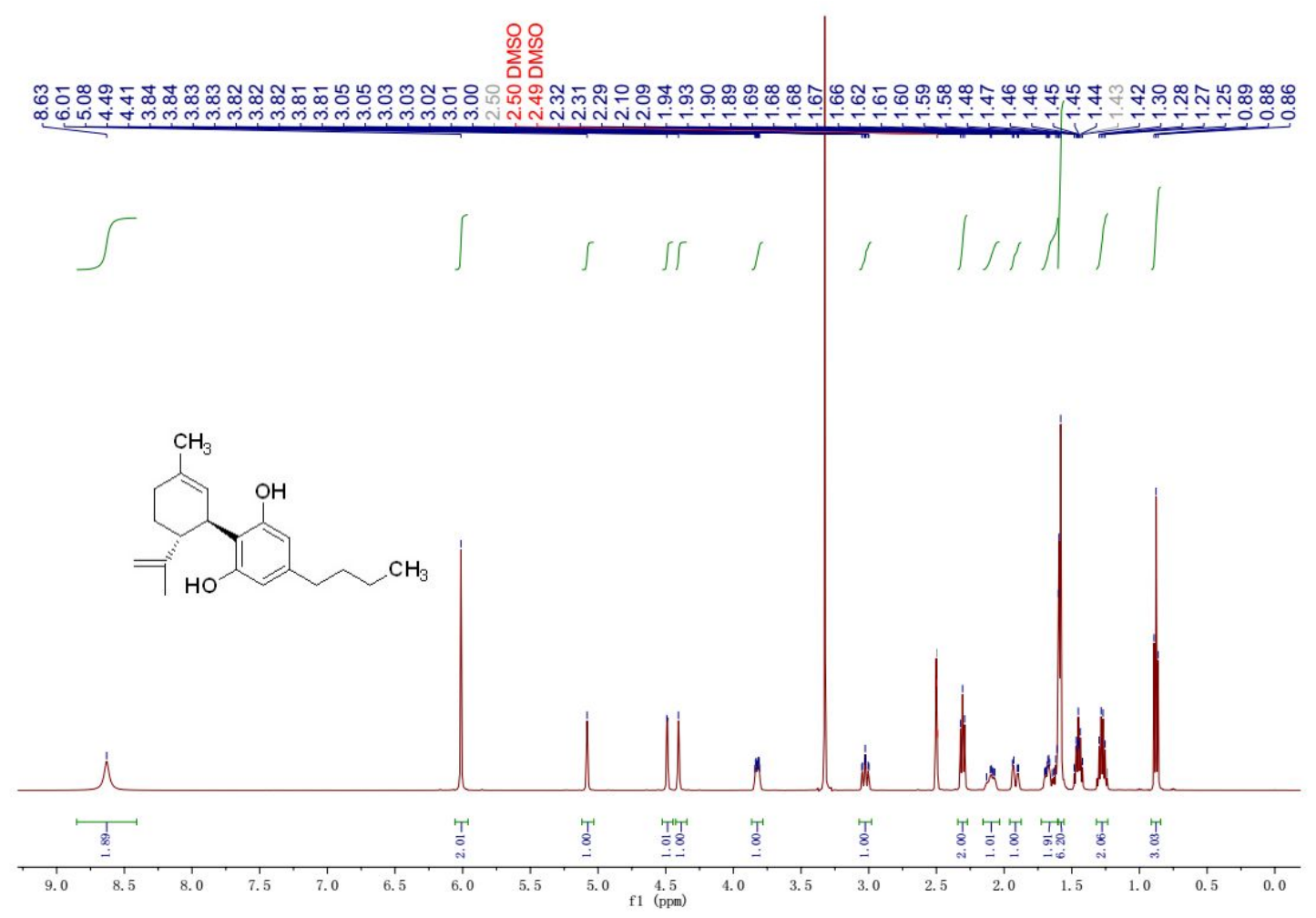

Figure S63 ${ }^{1} \mathrm{H}$ NMR(400 MHz) of $6 \mathbf{e}$ in DMSO- $d_{6}$
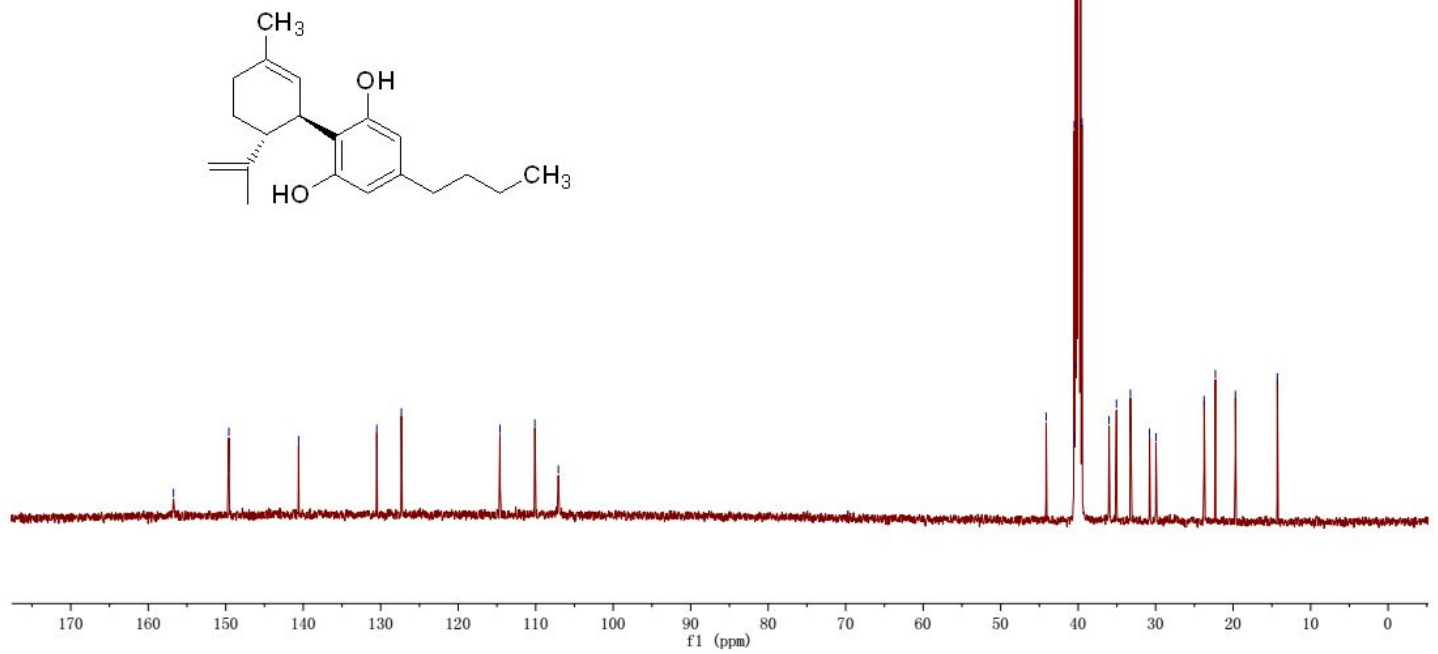

Figure $\mathbf{S 6 4}{ }^{13} \mathrm{C}\left\{{ }^{1} \mathrm{H}\right\} \mathrm{NMR}(125 \mathrm{MHz})$ of $\mathbf{6 e}$ in DMSO- $d_{6}$ 


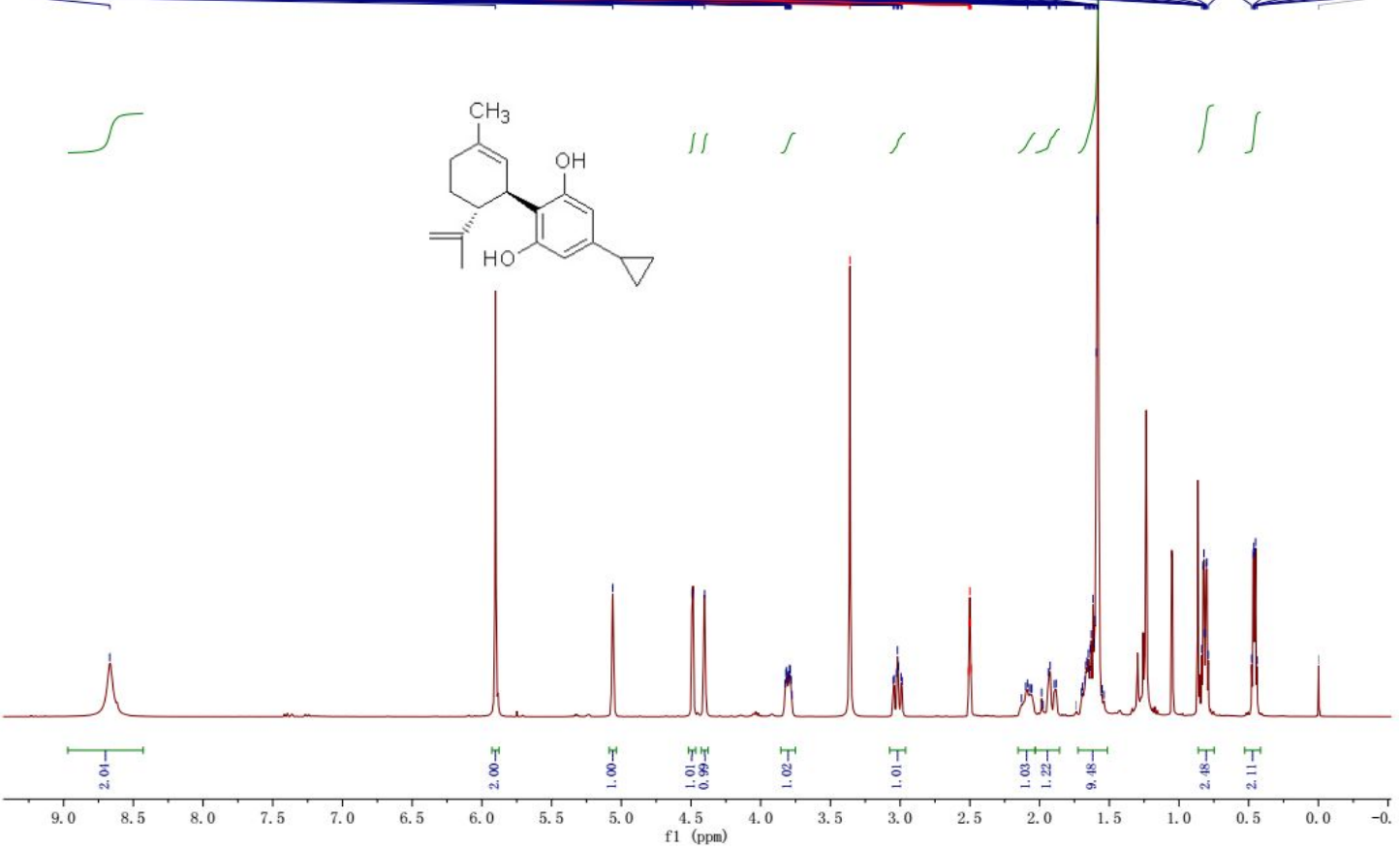

Figure $\mathbf{S 6 5}{ }^{1} \mathrm{H}$ NMR(400 MHz) of $\mathbf{6 f}$ in DMSO- $d_{6}$
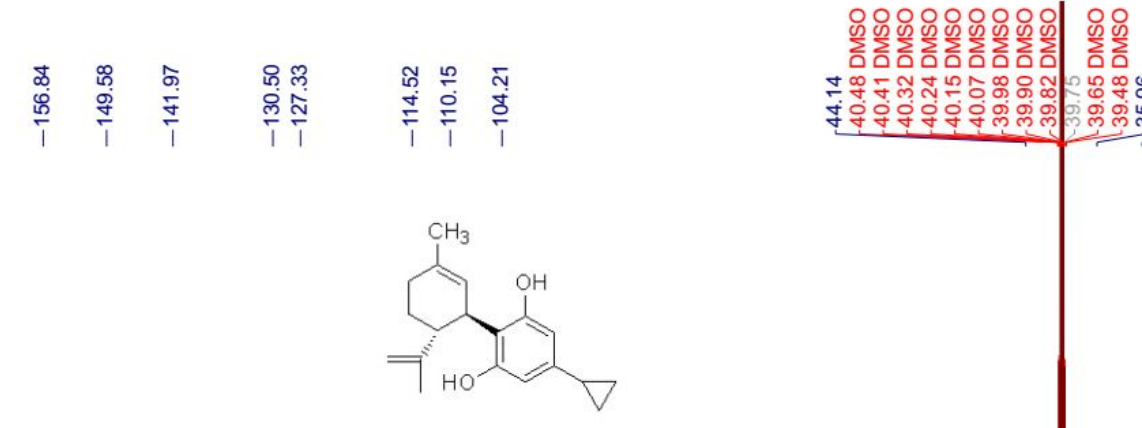

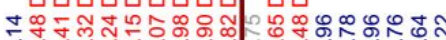

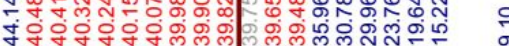
$\stackrel{+}{i}$
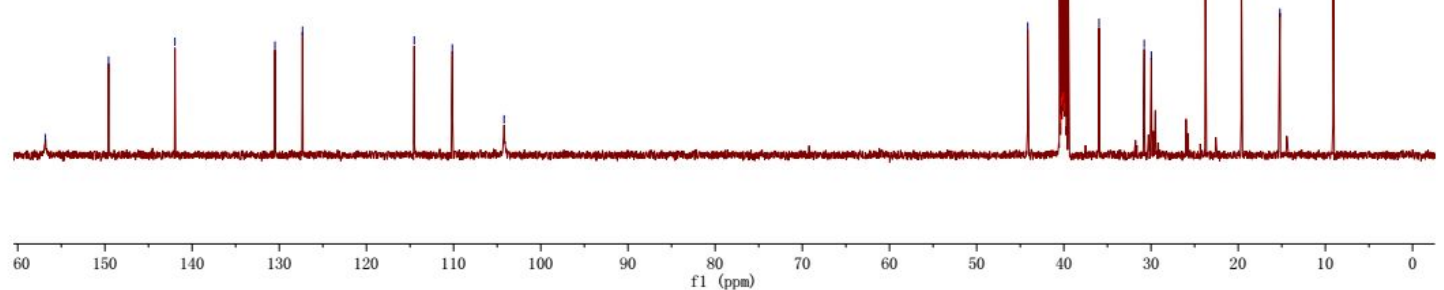

Figure $\mathbf{S 6 6}{ }^{13} \mathrm{C}\left\{{ }^{1} \mathrm{H}\right\} \mathrm{NMR}(125 \mathrm{MHz})$ of $\mathbf{6 f}$ in DMSO- $d_{6}$ 


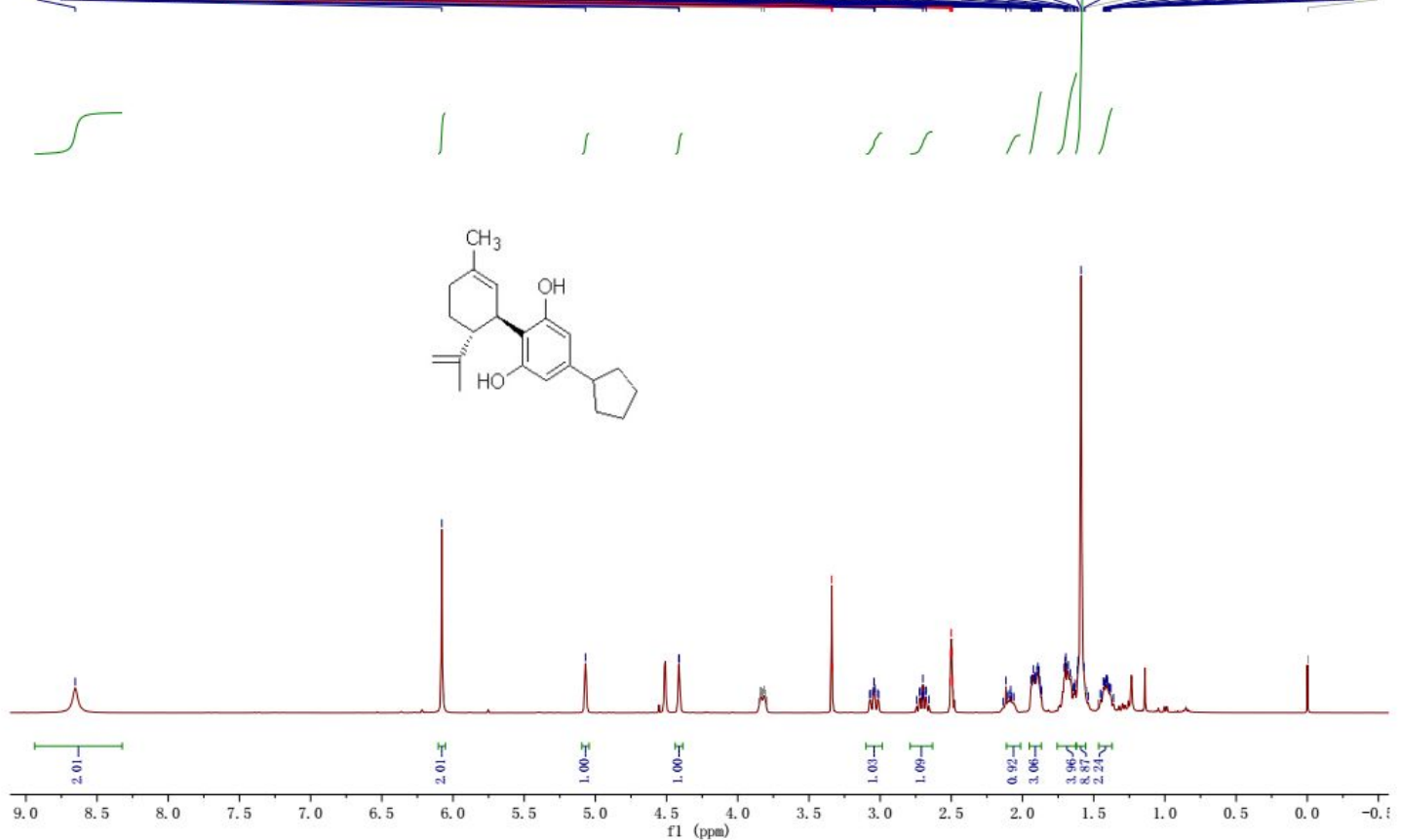

Figure $\mathbf{S 6 7}{ }^{1} \mathrm{H}$ NMR(400 MHz) of $\mathbf{6 g}$ in DMSO- $d_{6}$
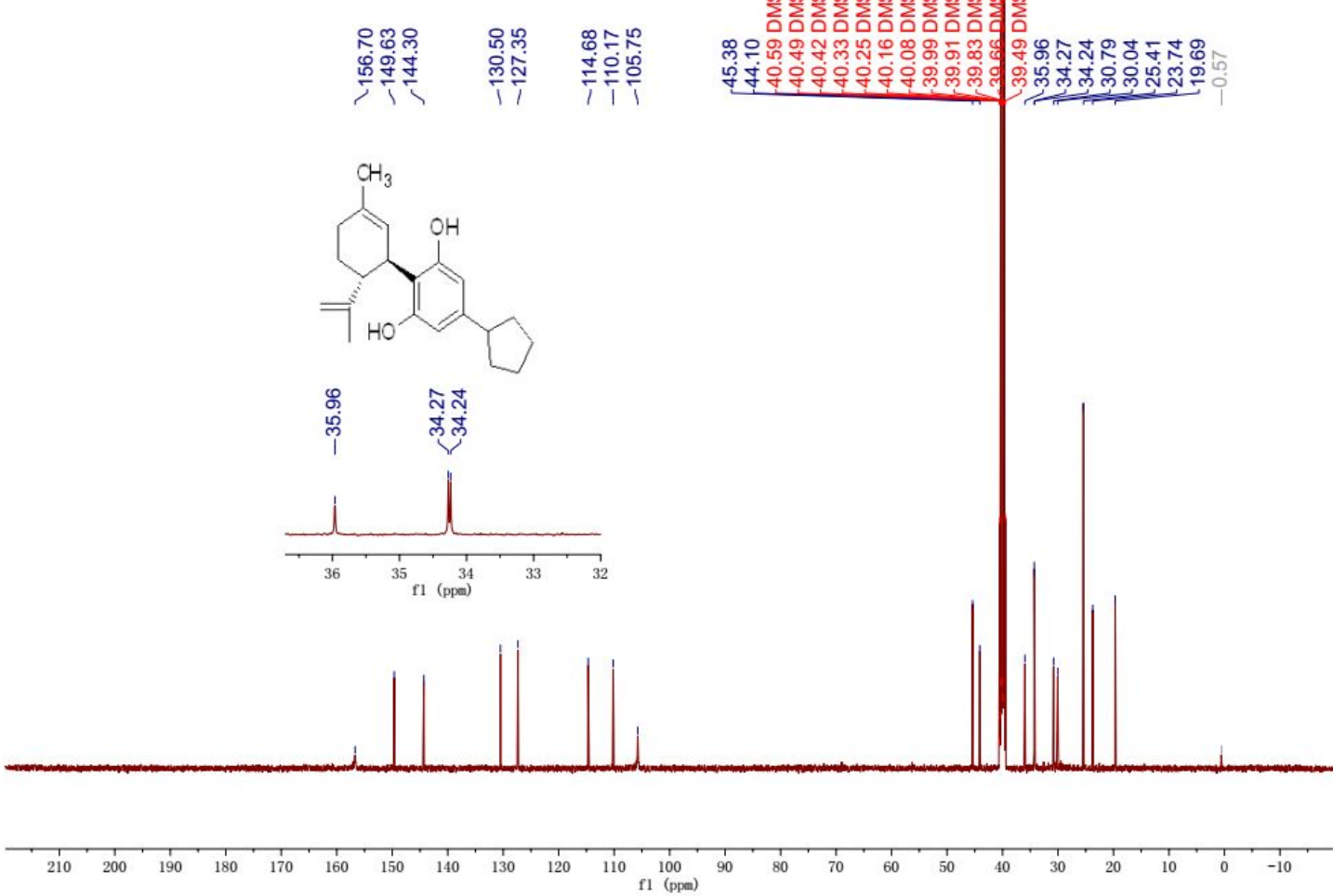

Figure $\mathbf{S 6 8}{ }^{13} \mathrm{C}\left\{{ }^{1} \mathrm{H}\right\} \mathrm{NMR}(125 \mathrm{MHz})$ of $\mathbf{6 g}$ in DMSO- $d_{6}$ 


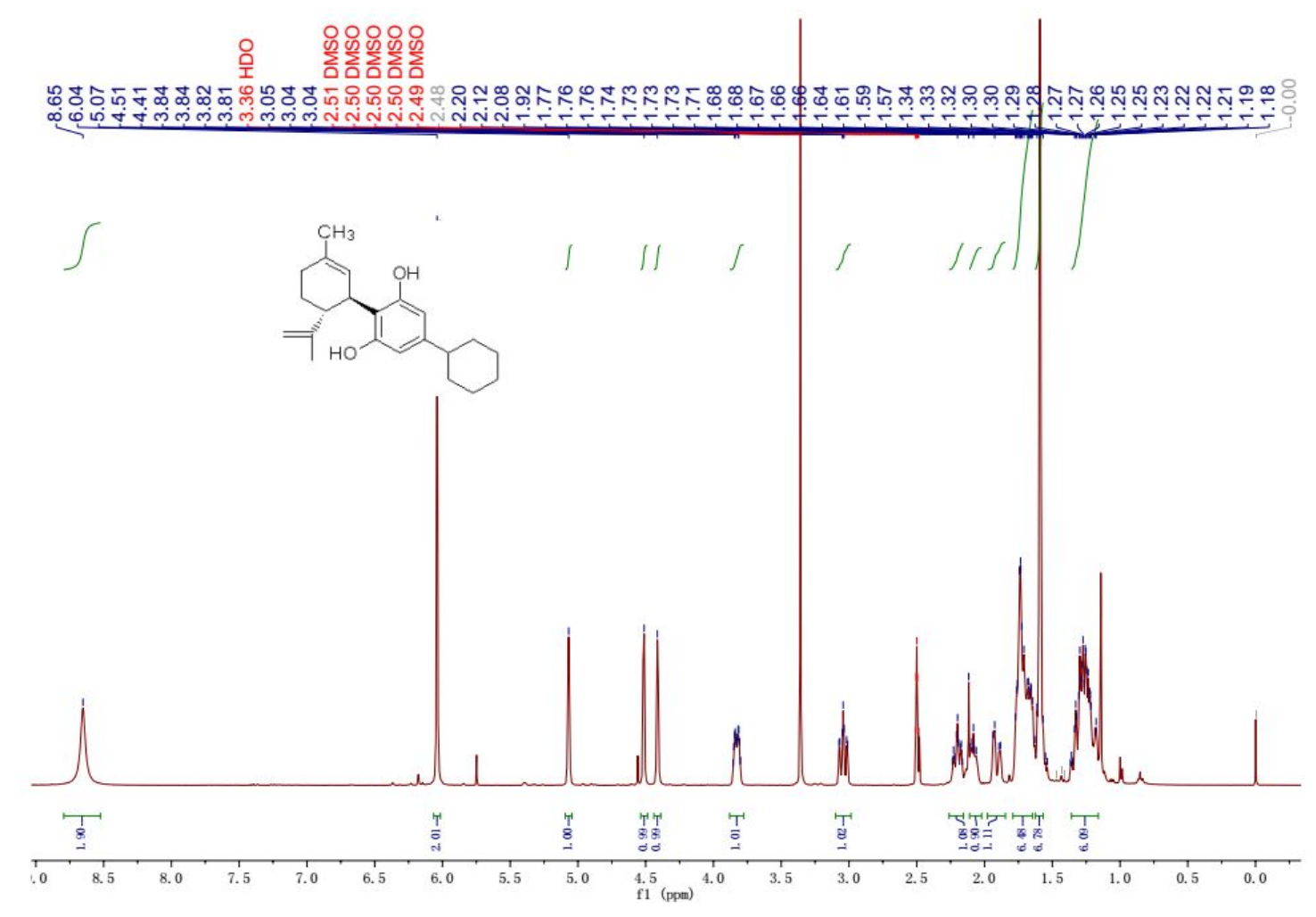

Figure S69 ${ }^{1} \mathrm{H}$ NMR(400 MHz) of $\mathbf{6 h}$ in DMSO- $d_{6}$
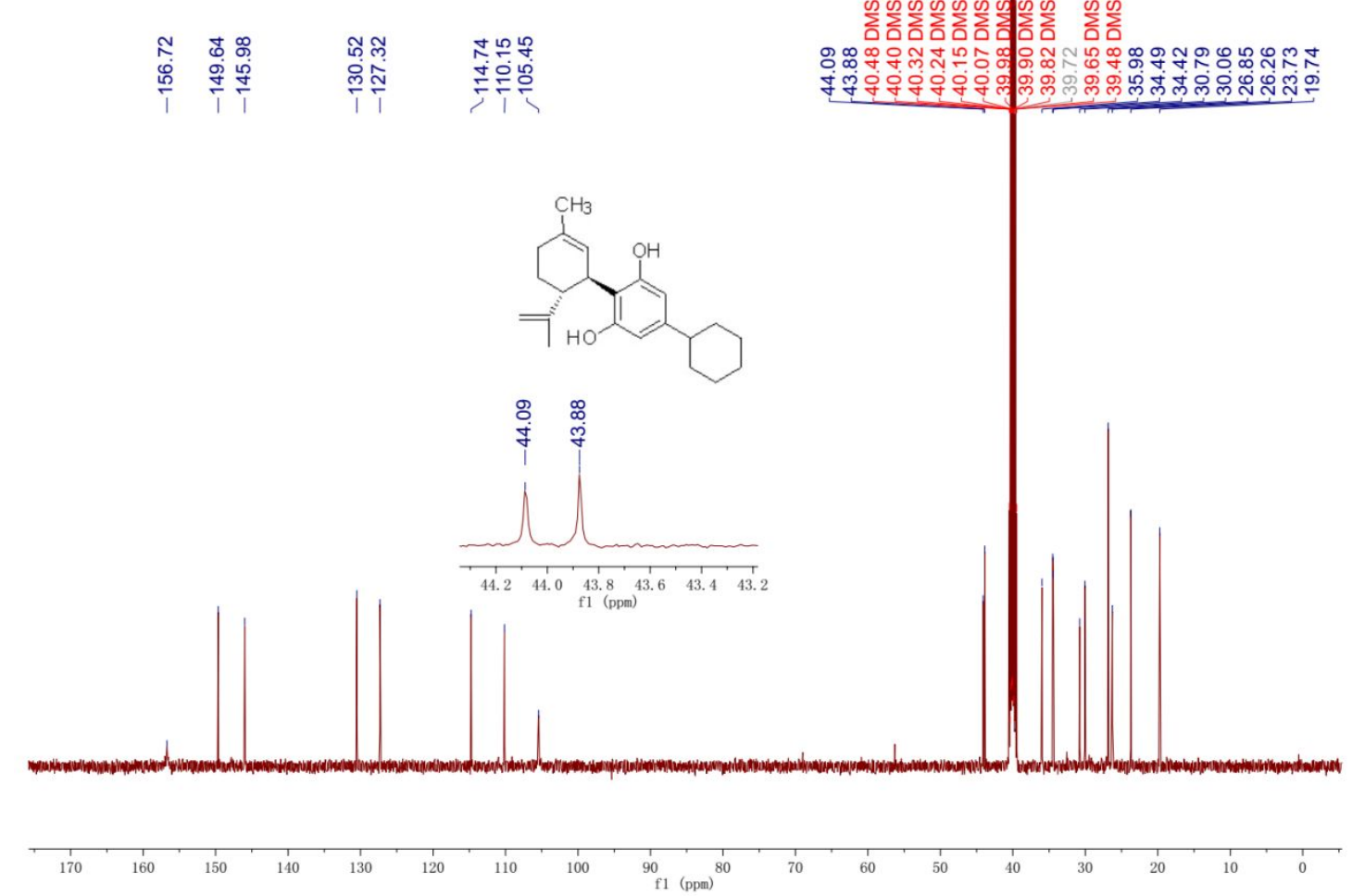

Figure $\mathbf{S 7 0}{ }^{13} \mathrm{C}\left\{{ }^{1} \mathrm{H}\right\} \mathrm{NMR}(125 \mathrm{MHz})$ of $\mathbf{6 h}$ in DMSO- $d_{6}$ 


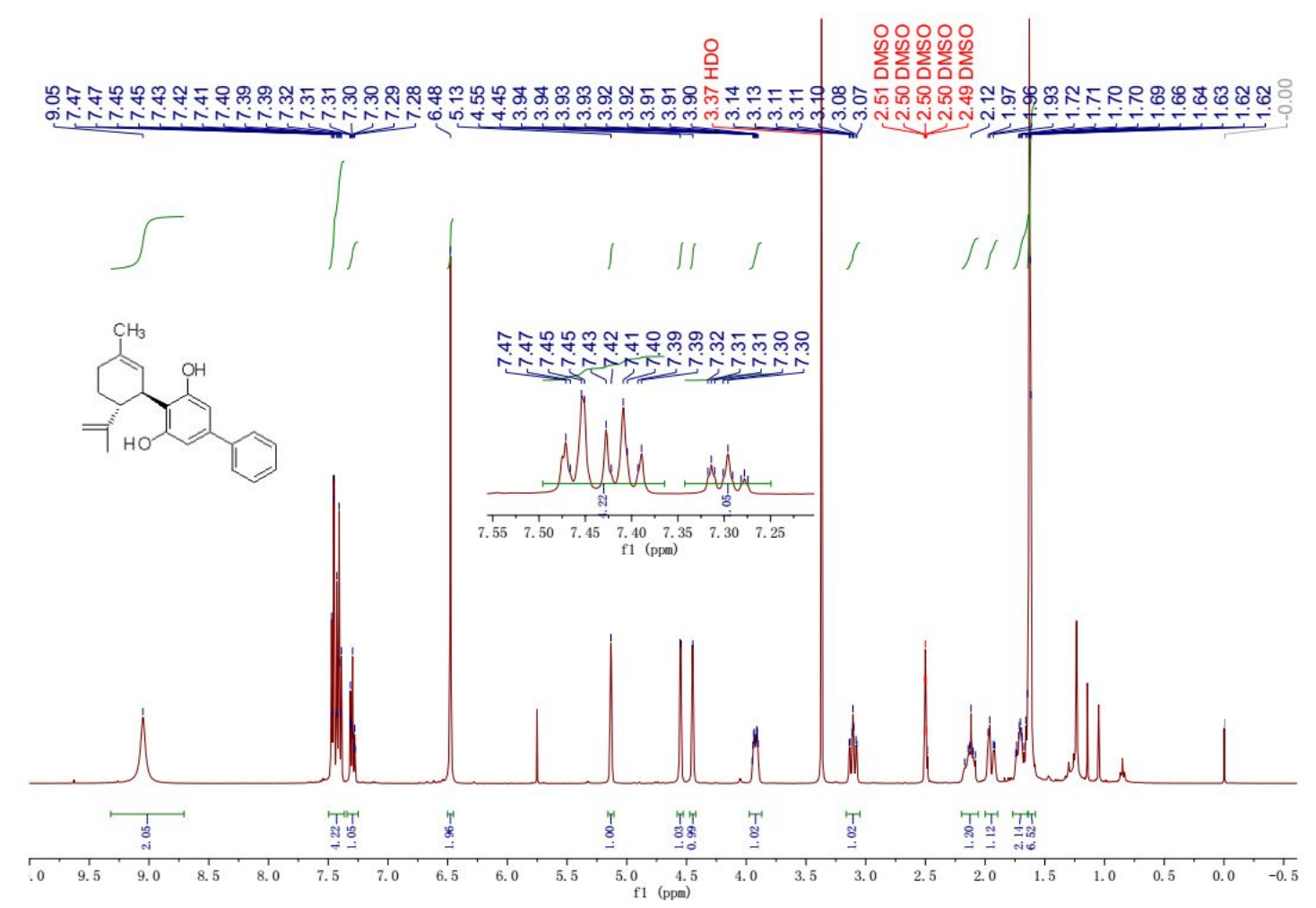

Figure S71 ${ }^{1} \mathrm{H}$ NMR(400 MHz) of $6 \mathbf{i}$ in DMSO- $d_{6}$

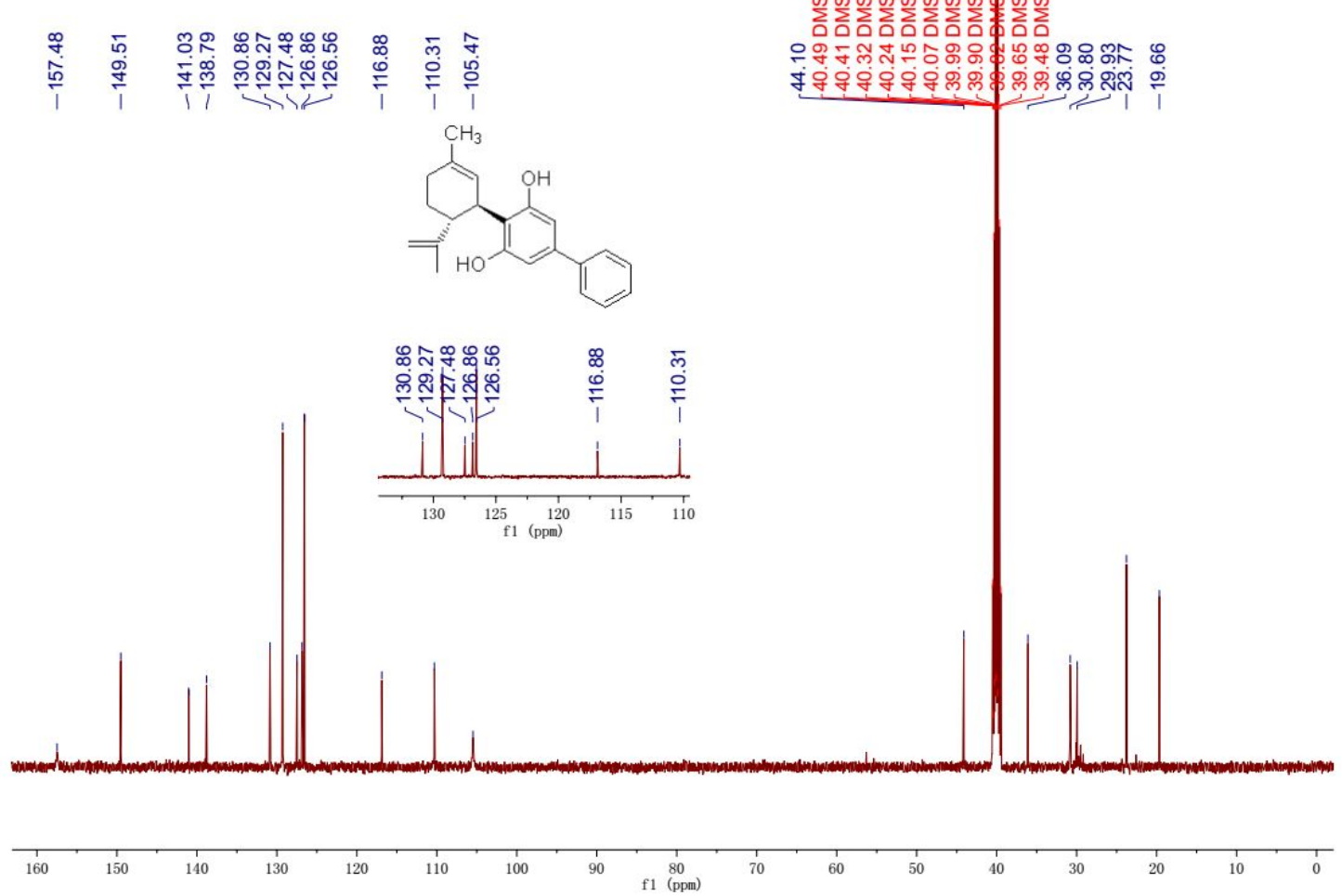

Figure $\mathbf{S} 72{ }^{13} \mathrm{C}\left\{{ }^{1} \mathrm{H}\right\}$ NMR(125 MHz) of $\mathbf{6 i}$ in DMSO- $d_{6}$ 

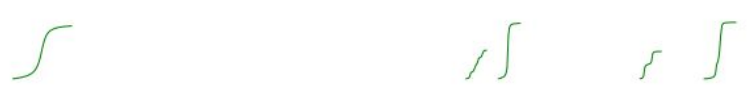<smiles>C=Cc1cc(O)c(C2C=C(C)CCC2C(C)=O)c(O)c1</smiles>
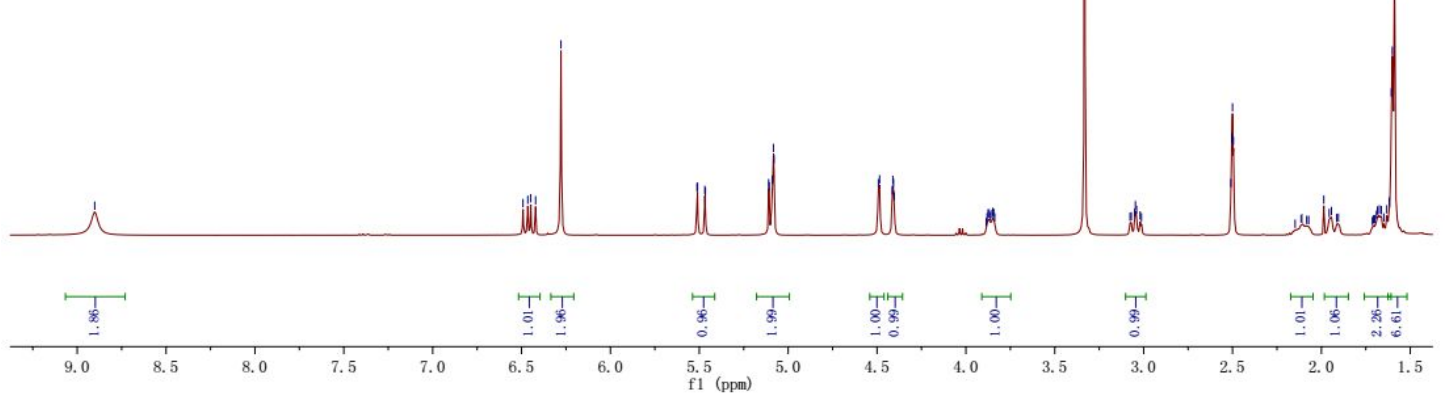

Figure $\mathbf{S 7 3}{ }^{1} \mathrm{H}$ NMR(400 MHz) of $\mathbf{6 j}$ in DMSO- $d_{6}$<smiles>C=Cc1cc(O)c([C@H]2C=C(C)CC[C@H]2C(=C)C)c(O)c1</smiles>
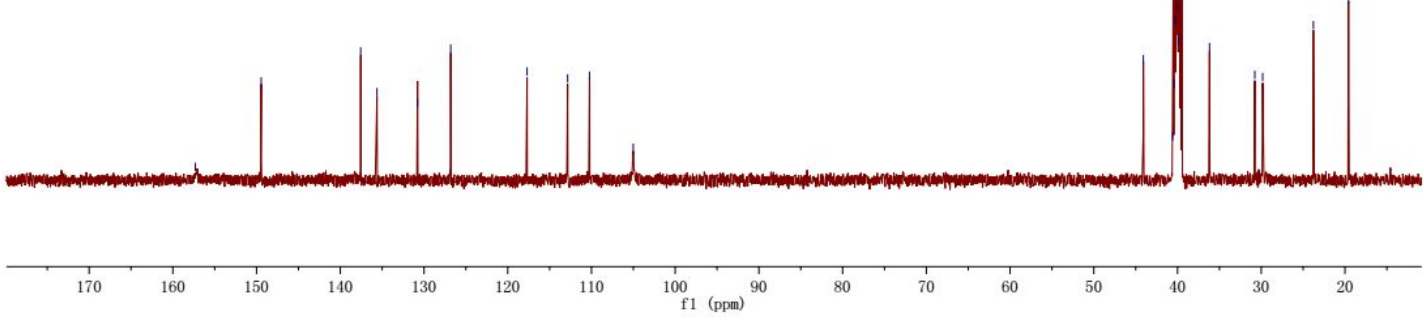

Figure $\mathbf{S 7 4}{ }^{13} \mathrm{C}\left\{{ }^{1} \mathrm{H}\right\} \operatorname{NMR}(125 \mathrm{MHz})$ of $\mathbf{6 j}$ in DMSO- $d_{6}$ 
$\sum_{0}^{\circ}$

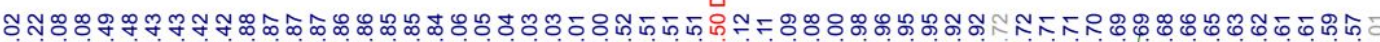

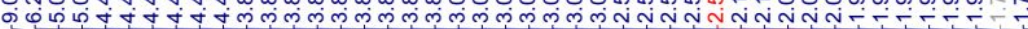

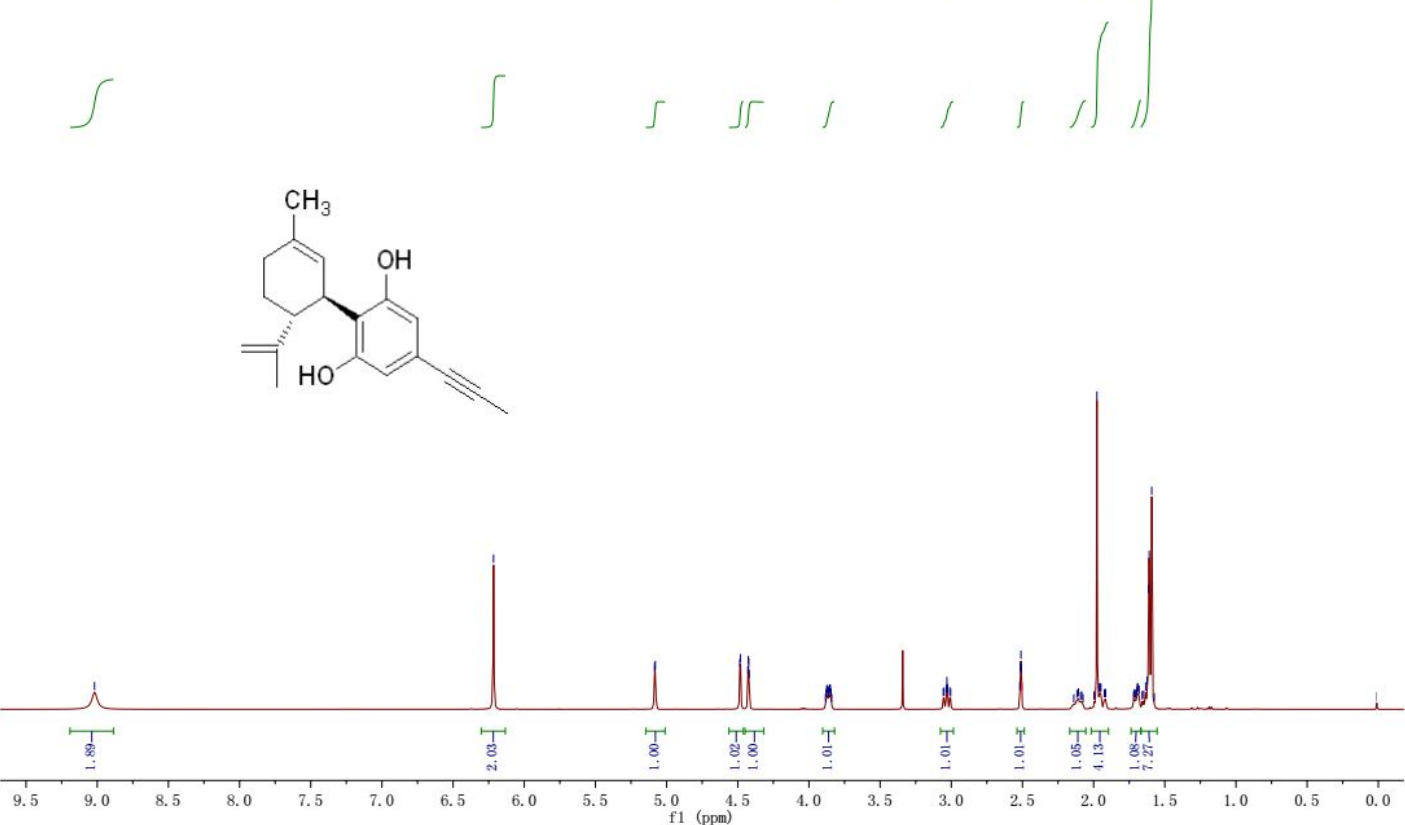

Figure $\mathbf{S 7 5}{ }^{1} \mathrm{H} \mathrm{NMR}(400 \mathrm{MHz})$ of $\mathbf{6 k}$ in DMSO- $d_{6}$

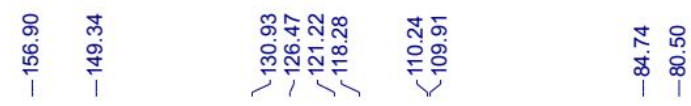

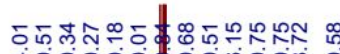

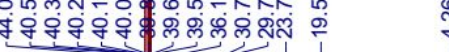
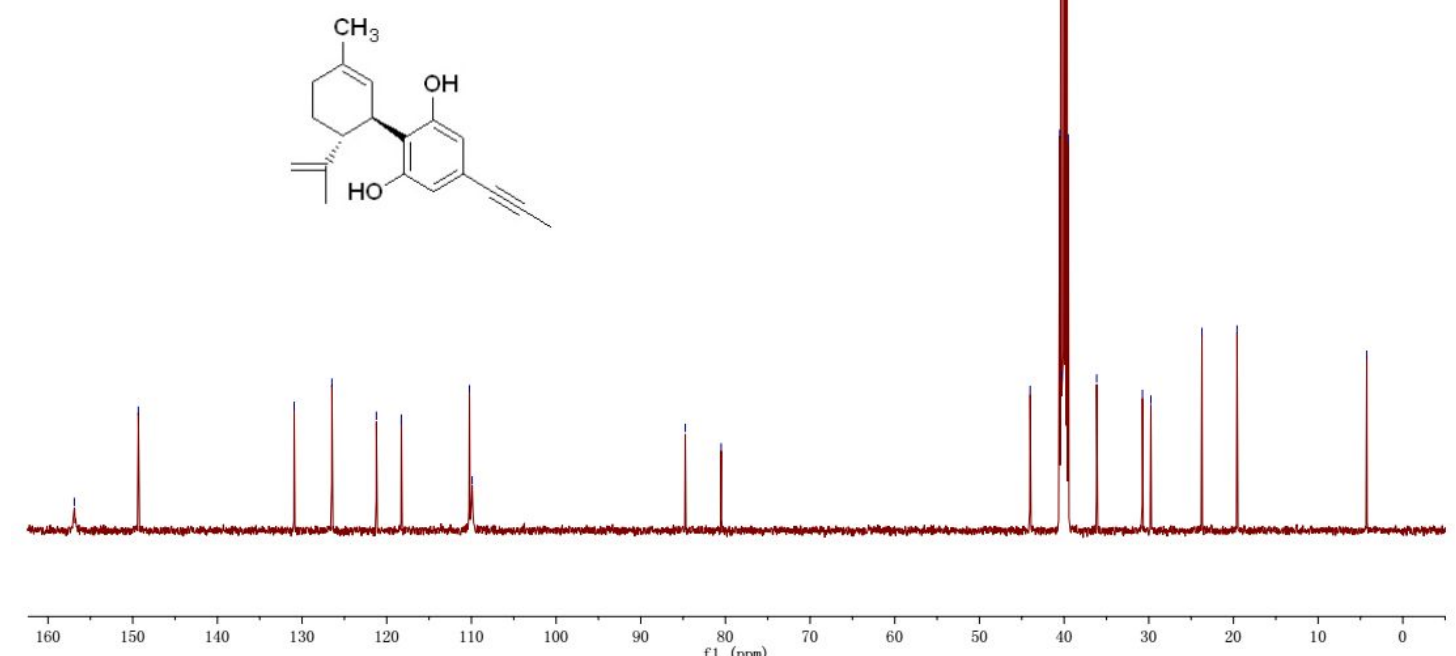

Figure $\mathbf{S} 76{ }^{13} \mathrm{C}\left\{{ }^{1} \mathrm{H}\right\} \mathrm{NMR}(125 \mathrm{MHz})$ of $\mathbf{6 k}$ in DMSO- $d_{6}$ 

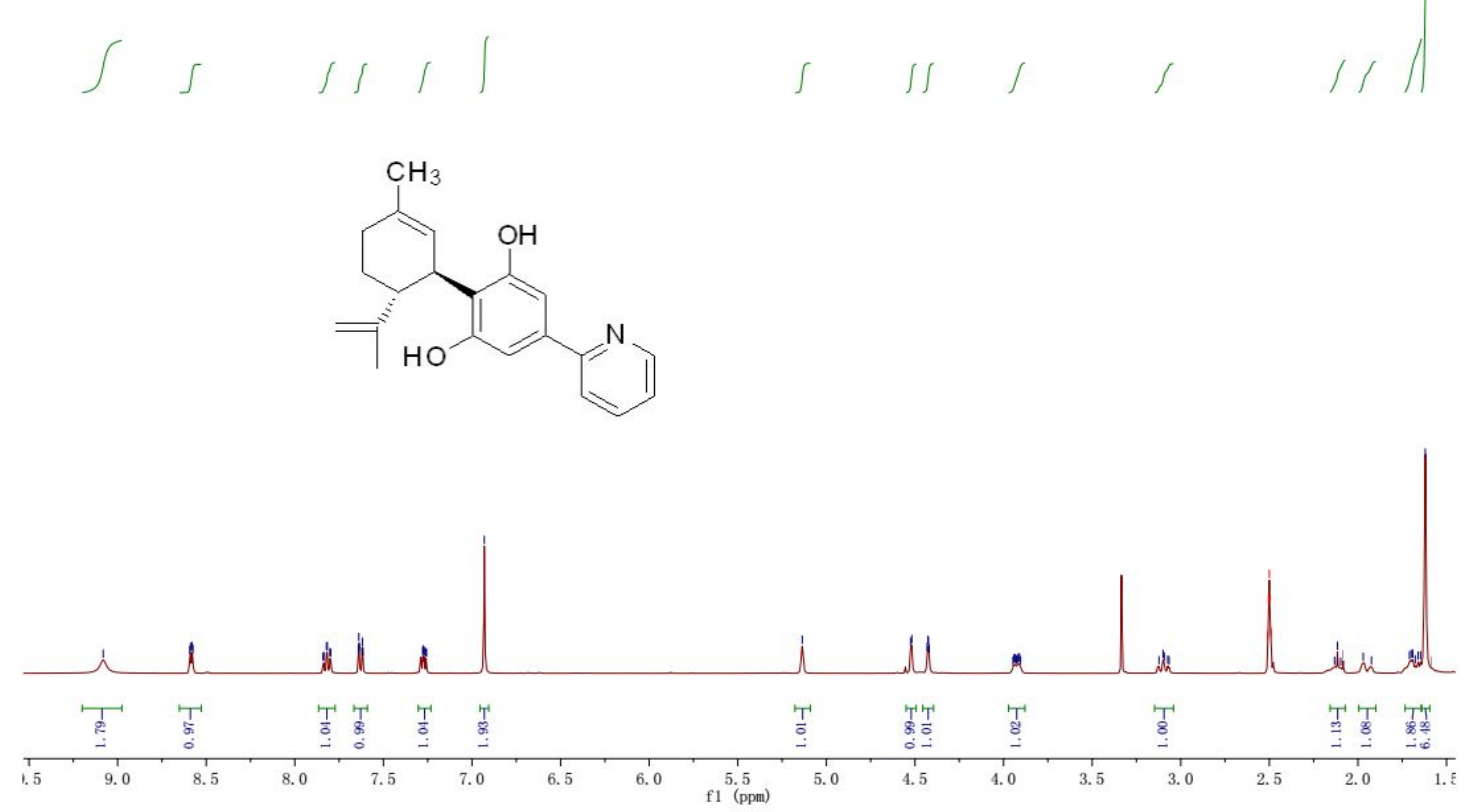

Figure $\mathbf{S 7 7}{ }^{1} \mathrm{H}$ NMR(400 MHz) of $\mathbf{6} 1$ in DMSO- $d_{6}$

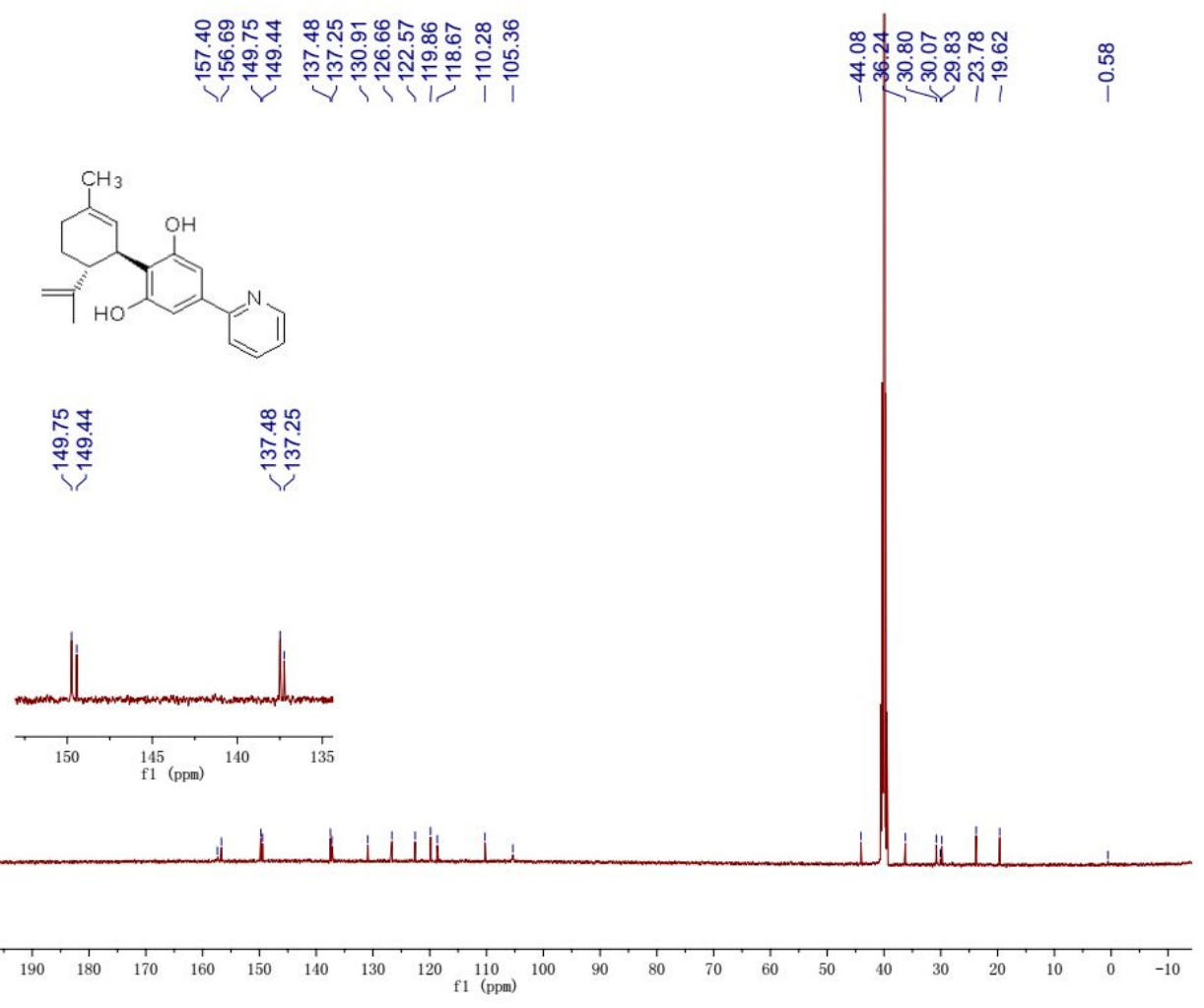

Figure $\mathbf{S 7 8}{ }^{13} \mathrm{C}\left\{{ }^{1} \mathrm{H}\right\}$ NMR $(125 \mathrm{MHz})$ of $\mathbf{6}$ in DMSO- $d_{6}$ 


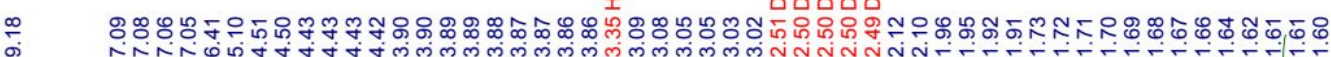

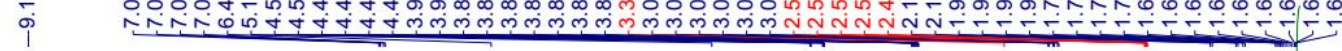
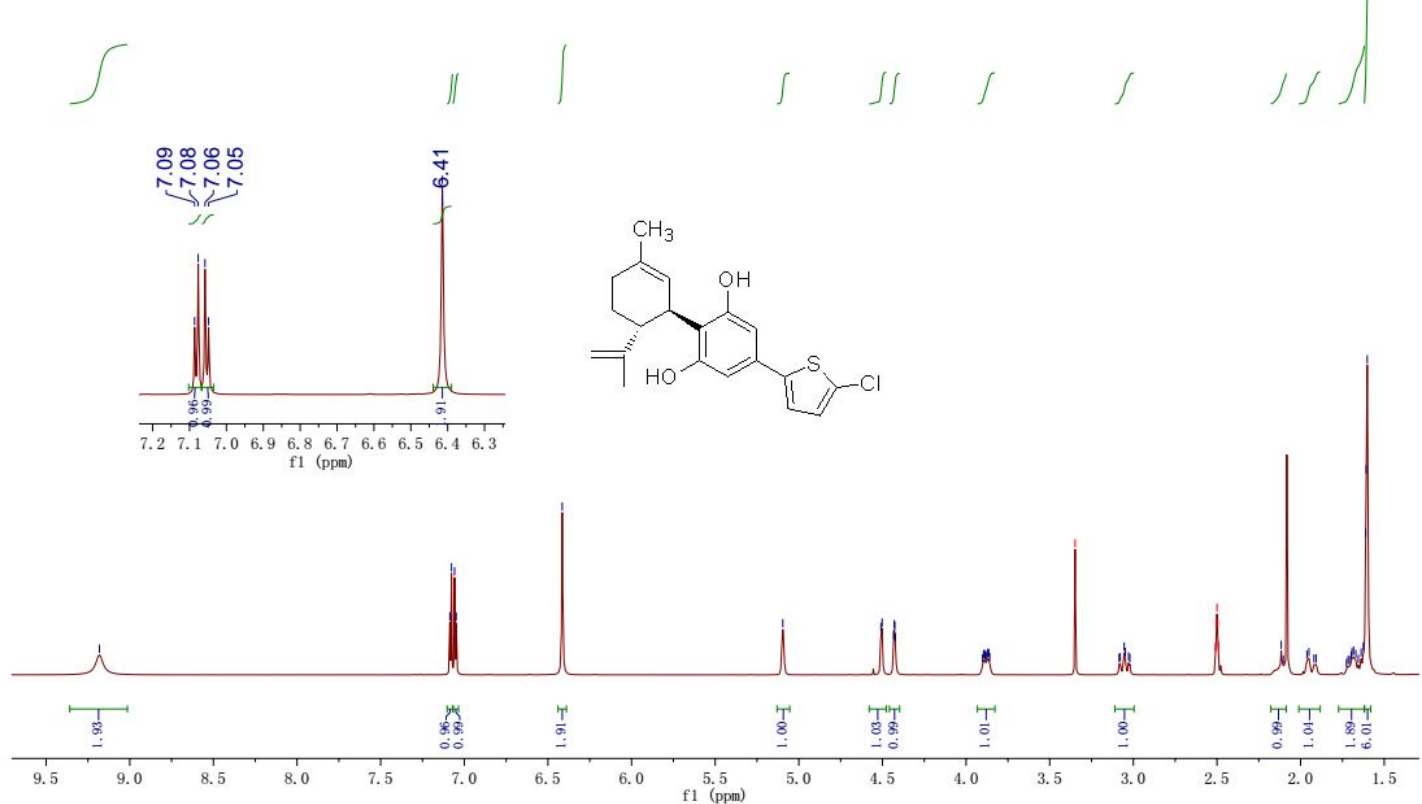

Figure $\mathbf{S 7 9}{ }^{1} \mathrm{H}$ NMR $(400 \mathrm{MHz})$ of $\mathbf{6 m}$ in DMSO- $d_{6}$
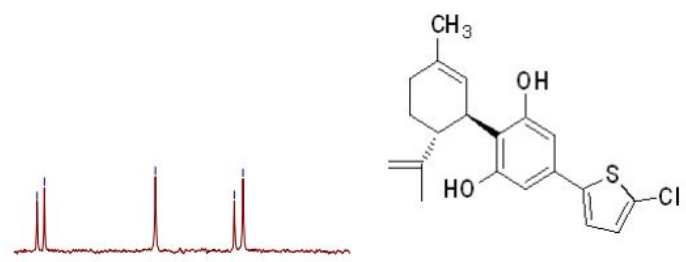

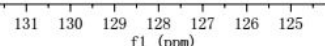

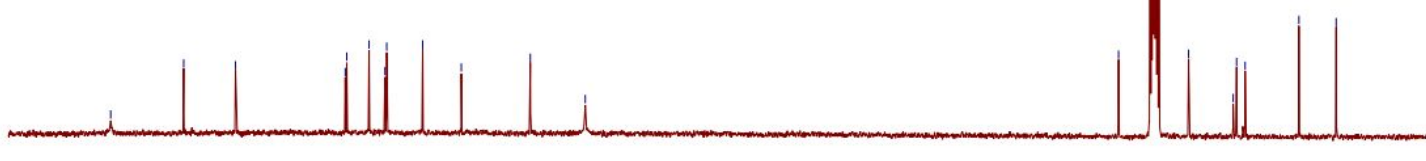

$160 \quad 150 \quad 140$

Figure $\mathbf{S 8 0}{ }^{13} \mathrm{C}\left\{{ }^{1} \mathrm{H}\right\}$ NMR(125 MHz) of $\mathbf{6 m}$ in DMSO- $d_{6}$ 


\section{Section 2: X-Ray Crystallographic Data}

Table S1. X-ray Crystal Data for (-)-CBD

Method for crystal growth: The single-crystal of (-)-CBD was grown from the solution of n-heptane. Single Crystal X-ray Diffraction (SCXRD). X-ray diffractions of all single crystals were carried out at 100(2) $\mathrm{K}$ on a Bruker D8 VENTURE diffractometer using $\mathrm{Cu}-\mathrm{K} \alpha$ radiation $(\lambda$ $=1.54184 \AA$ ). Integration and scaling of intensity data was performed using the SAINT program. Data were corrected for the effects of absorption using SADABS. The structures were solved by direct method and refined with full-matrix least-squares technique using SHELX-2014 software. Non-hydrogen atoms were refined with anisotropic displacement parameters, and hydrogen atoms were placed in calculated positions and refined with a riding model.

\begin{tabular}{|c|c|}
\hline Compound & $(-)-C B D$ \\
\hline Identification code & $(-)-\mathrm{CBD}$ \\
\hline Empirical formula & $\mathrm{C}_{21} \mathrm{H}_{30} \mathrm{O}_{2}$ \\
\hline Formula weight & 314.45 \\
\hline Temperature/K & 100.0 \\
\hline Crystal system & monoclinic \\
\hline Space group & $\mathrm{P} 2_{1}$ \\
\hline \multirow[t]{6}{*}{ Unit cell parameters } & $a=10.4032(3) \AA$ \\
\hline & $\mathrm{b}=10.8935(3) \AA$ \\
\hline & $c=16.6918(4) \AA$ \\
\hline & $\alpha=90^{\circ}$ \\
\hline & $\beta=95.490(2)^{\circ}$ \\
\hline & $\gamma=90^{\circ}$ \\
\hline Volume $/ \AA^{3}$ & $1882.96(9)$ \\
\hline Z & 4 \\
\hline$\rho_{\text {calc }} \mathrm{g} / \mathrm{cm}^{3}$ & 1.109 \\
\hline$\mu / \mathrm{mm}^{-1}$ & 0.534 \\
\hline $\mathrm{F}(000)$ & 688.0 \\
\hline Crystal size $/ \mathrm{mm}^{3}$ & $0.28 \times 0.16 \times 0.12$ \\
\hline Radiation & $\mathrm{CuK} \alpha(\lambda=1.54184)$ \\
\hline Theta range for data collection ${ }^{\circ}$ & 5.318 to 149.028 \\
\hline Index ranges & $\begin{array}{c}-12 \leqslant \mathrm{~h} \leqslant 13,-13 \leqslant \mathrm{k} \leqslant \\
13,-20 \leqslant 1 \leqslant 19\end{array}$ \\
\hline Reflections collected & 21756 \\
\hline Independent reflections & $\begin{array}{c}7417\left[\mathrm{R}_{\text {int }}=0.0420, \mathrm{R}_{\text {sigma }}=\right. \\
0.0422]\end{array}$ \\
\hline Data/restraints/parameters & $7417 / 1 / 429$ \\
\hline Goodness-of-fit on $\mathrm{F}^{2}$ & 1.043 \\
\hline Final $R$ indexes $[\mathrm{I}>=2 \sigma(\mathrm{I})]$ & $\mathrm{R}_{1}=0.0357, \mathrm{wR}_{2}=0.0852$ \\
\hline Final R indexes [all data] & $\mathrm{R}_{1}=0.0382, \mathrm{wR}_{2}=0.0875$ \\
\hline Largest diff. peak/hole / e $\AA^{-3}$ & $0.16 /-0.17$ \\
\hline Flack parameter & $0.04(10)$ \\
\hline
\end{tabular}


Table S2 Fractional atomic coordinates and isotropic or equivalent isotropic displacement parameters $\left(\AA^{2}\right)$ for (-)-CBD

\begin{tabular}{|c|c|c|c|c|}
\hline & $x$ & $y$ & $z$ & $\boldsymbol{U}_{\text {iso }} * / \boldsymbol{U}_{\mathrm{eq}}$ \\
\hline $\mathrm{O} 3$ & $0.77115(15)$ & 0.31895 (14) & $0.24359(9)$ & 0.0220 \\
\hline $\mathrm{O} 2$ & $0.54139(13)$ & $0.27094(13)$ & $0.31147(9)$ & $0.0216(3)$ \\
\hline $\mathrm{H} 2$ & 0.523378 & 0.216030 & 0.343910 & $0.032 *$ \\
\hline $\mathrm{O} 1$ & $0.10815(15)$ & $0.39045(15)$ & $0.34595(9)$ & 0.0248 \\
\hline $\mathrm{O} 4$ & $1.00993(14)$ & 0.64977 (14) & $0.14218(9)$ & $0.0227(3)$ \\
\hline $\mathrm{H} 4$ & 1.033009 & 0.594443 & 0.111558 & $0.034^{*}$ \\
\hline $\mathrm{C} 32$ & $0.88798(18)$ & 0.47908 (19) & $0.18959(11)$ & 0.0171 \\
\hline $\mathrm{C} 16$ & $0.43721(19)$ & $0.34980(18)$ & $0.29720(12)$ & 0.0174 \\
\hline $\mathrm{C} 36$ & $0.91666(19)$ & $0.67204(19)$ & $0.26377(12)$ & 0.0200 \\
\hline H36 & 0.950912 & 0.752909 & 0.267364 & $0.024 *$ \\
\hline $\mathrm{C} 33$ & $0.81760(18)$ & $0.43602(19)$ & $0.25145(12)$ & 0.0173 \\
\hline $\mathrm{C} 13$ & $0.2446(2)$ & $0.52305(19)$ & $0.27496(12)$ & $0.0207(4)$ \\
\hline H13 & 0.179373 & 0.584363 & 0.270343 & $0.025^{*}$ \\
\hline $\mathrm{C} 31$ & $0.90792(19)$ & $0.40004(18)$ & $0.11677(11)$ & $0.0176(4)$ \\
\hline H31 & 0.875975 & 0.315618 & 0.127529 & $0.021^{*}$ \\
\hline $\mathrm{C} 30$ & $1.05084(19)$ & $0.39038(19)$ & $0.10564(12)$ & 0.0200 \\
\hline $\mathrm{H} 30$ & 1.108398 & 0.375141 & 0.152257 & $0.024^{*}$ \\
\hline $\mathrm{C} 37$ & $0.93741(18)$ & $0.59901(19)$ & $0.19823(12)$ & $0.0181(4)$ \\
\hline $\mathrm{C} 15$ & $0.45720(19)$ & 0.45441 (19) & $0.25266(12)$ & $0.0189(4)$ \\
\hline H15 & 0.536560 & 0.465670 & 0.229804 & $0.023^{*}$ \\
\hline $\mathrm{C} 17$ & $0.3811(2)$ & $0.6597(2)$ & $0.19595(13)$ & 0.0239 \\
\hline H17A & 0.304482 & 0.713148 & 0.197816 & $0.029 *$ \\
\hline H17B & 0.389013 & 0.639140 & 0.138865 & $0.029^{*}$ \\
\hline $\mathrm{C} 34$ & $0.79778(19)$ & $0.50845(19)$ & $0.31801(12)$ & $0.0196(4)$ \\
\hline H34 & 0.750979 & 0.476142 & 0.359389 & $0.024 *$ \\
\hline $\mathrm{C} 14$ & $0.3602(2)$ & $0.54309(19)$ & $0.24154(12)$ & $0.0200(4)$ \\
\hline $\mathrm{C} 4$ & $0.2975(2)$ & $0.09126(19)$ & 0.31107 (13) & $0.0219(4)$ \\
\hline $\mathrm{H} 4 \mathrm{~A}$ & 0.384636 & 0.089814 & 0.290440 & $0.026^{*}$ \\
\hline $\mathrm{C} 35$ & $0.84590(19)$ & $0.6277(2)$ & $0.32444(12)$ & $0.0201(4)$ \\
\hline $\mathrm{C} 25$ & $0.82978(19)$ & $0.44822(19)$ & 0.03915 (11) & $0.0185(4)$ \\
\hline
\end{tabular}




\begin{tabular}{|c|c|c|c|c|}
\hline $\mathrm{H} 25$ & 0.849828 & 0.537515 & 0.034170 & $0.022 *$ \\
\hline $\mathrm{C} 12$ & $0.22360(19)$ & $0.41394(19)$ & $0.31512(12)$ & $0.0189(4)$ \\
\hline $\mathrm{C} 11$ & 0.31907 (19) & $0.32367(18)$ & $0.32675(12)$ & $0.0171(4)$ \\
\hline $\mathrm{C} 10$ & $0.29471(18)$ & $0.20310(18)$ & $0.36813(12)$ & $0.0180(4)$ \\
\hline $\mathrm{H} 10$ & 0.206149 & 0.207424 & 0.386564 & $0.022 *$ \\
\hline $\mathrm{C} 28$ & $1.1019(2)$ & $0.4015(2)$ & $0.03590(13)$ & $0.0223(4)$ \\
\hline $\mathrm{C} 26$ & $0.8782(2)$ & $0.3823(2)$ & $-0.03383(12)$ & $0.0232(4)$ \\
\hline $\mathrm{H} 26 \mathrm{~A}$ & 0.871539 & 0.292374 & -0.026749 & $0.028 *$ \\
\hline H26B & 0.823464 & 0.405516 & -0.083295 & $0.028 *$ \\
\hline C38 & $0.8219(2)$ & $0.7085(2)$ & $0.39524(13)$ & $0.0263(5)$ \\
\hline $\mathrm{H} 38 \mathrm{~A}$ & 0.764503 & 0.664185 & 0.429372 & $0.032 *$ \\
\hline H38B & 0.775813 & 0.783329 & 0.374699 & $0.032 *$ \\
\hline $\mathrm{C} 3$ & 0.1985 (2) & $0.1031(2)$ & $0.23855(14)$ & $0.0261(5)$ \\
\hline $\mathrm{C} 23$ & $0.6854(2)$ & $0.4364(2)$ & $0.04210(12)$ & $0.0225(4)$ \\
\hline $\mathrm{C} 18$ & $0.5011(2)$ & $0.7308(2)$ & $0.22913(14)$ & $0.0270(5)$ \\
\hline H18A & 0.494804 & 0.748506 & 0.286787 & $0.032 *$ \\
\hline H18B & 0.578119 & 0.678464 & 0.225311 & $0.032 *$ \\
\hline $\mathrm{C} 27$ & $1.0179(2)$ & $0.4169(2)$ & $-0.04257(12)$ & $0.0247(4)$ \\
\hline $\mathrm{H} 27 \mathrm{~A}$ & 1.051648 & 0.364560 & -0.084286 & $0.030 *$ \\
\hline H27B & 1.021704 & 0.503368 & -0.060503 & $0.030 *$ \\
\hline $\mathrm{C} 2$ & $0.2353(2)$ & $0.1243(2)$ & $0.16650(14)$ & $0.0306(5)$ \\
\hline $\mathrm{H} 2 \mathrm{~A}$ & 0.172564 & 0.133880 & 0.121705 & $0.037 *$ \\
\hline $\mathrm{H} 2 \mathrm{~B}$ & 0.324592 & 0.129956 & 0.159324 & $0.037 *$ \\
\hline C39 & $0.9443(2)$ & $0.7474(2)$ & $0.44780(13)$ & $0.0269(5)$ \\
\hline H39A & 1.004010 & 0.788047 & 0.413375 & $0.032 *$ \\
\hline H39B & 0.920525 & 0.808227 & 0.487903 & $0.032 *$ \\
\hline C19 & $0.5197(2)$ & $0.85060(19)$ & $0.18538(13)$ & $0.0240(4)$ \\
\hline H19A & 0.523988 & 0.833077 & 0.127502 & $0.029 *$ \\
\hline H19B & 0.443581 & 0.903693 & 0.190268 & $0.029 *$ \\
\hline C9 & $0.3890(2)$ & $0.1847(2)$ & $0.44223(12)$ & $0.0217(4)$ \\
\hline H9 & 0.414205 & 0.255099 & 0.473476 & $0.026^{*}$ \\
\hline $\mathrm{C} 5$ & $0.2854(2)$ & $-0.0261(2)$ & $0.36031(15)$ & $0.0313(5)$ \\
\hline $\mathrm{H} 5 \mathrm{~A}$ & 0.205335 & -0.022691 & 0.387823 & $0.038 *$ \\
\hline
\end{tabular}




\begin{tabular}{|c|c|c|c|c|}
\hline H5B & 0.279705 & -0.097971 & 0.323875 & $0.038^{*}$ \\
\hline $\mathrm{C} 40$ & $1.0144(2)$ & $0.6406(2)$ & $0.49183(13)$ & 0.0252 (4) \\
\hline $\mathrm{H} 40 \mathrm{~A}$ & 1.040738 & 0.581056 & 0.451711 & $0.030 *$ \\
\hline $\mathrm{H} 40 \mathrm{~B}$ & 0.953960 & 0.598366 & 0.524997 & $0.030 *$ \\
\hline $\mathrm{C} 7$ & $0.4391(2)$ & 0.0767 (2) & $0.46669(13)$ & $0.0278(5)$ \\
\hline $\mathrm{C} 29$ & $1.2456(2)$ & $0.3968(3)$ & $0.03120(14)$ & $0.0310(5)$ \\
\hline H29A & 1.289325 & 0.383215 & 0.085113 & $0.047 *$ \\
\hline H29B & 1.274792 & 0.474591 & 0.009718 & $0.047 *$ \\
\hline $\mathrm{H} 29 \mathrm{C}$ & 1.266213 & 0.329380 & -0.004311 & $0.047 *$ \\
\hline $\mathrm{C} 22$ & $0.6294(2)$ & $0.3094(2)$ & $0.04441(15)$ & $0.0320(5)$ \\
\hline $\mathrm{H} 22 \mathrm{~A}$ & 0.648262 & 0.264180 & -0.003840 & $0.048 *$ \\
\hline $\mathrm{H} 22 \mathrm{~B}$ & 0.535713 & 0.314992 & 0.046167 & $0.048 *$ \\
\hline $\mathrm{H} 22 \mathrm{C}$ & 0.667759 & 0.266343 & 0.092422 & $0.048^{*}$ \\
\hline C6 & 0.4019 (3) & $-0.0407(2)$ & $0.42284(15)$ & $0.0339(5)$ \\
\hline H6A & 0.381757 & -0.103694 & 0.462518 & $0.041 *$ \\
\hline H6B & 0.476385 & -0.070445 & 0.395612 & $0.041 *$ \\
\hline $\mathrm{C} 8$ & $0.5309(3)$ & $0.0657(3)$ & $0.54180(14)$ & $0.0388(6)$ \\
\hline H8A & 0.555712 & 0.147914 & 0.561531 & $0.058 *$ \\
\hline H8B & 0.608076 & 0.020564 & 0.529594 & $0.058 *$ \\
\hline $\mathrm{H} 8 \mathrm{C}$ & 0.488453 & 0.021618 & 0.583157 & $0.058 *$ \\
\hline $\mathrm{C} 21$ & $0.6575(3)$ & $1.0418(2)$ & $0.17635(15)$ & $0.0314(5)$ \\
\hline $\mathrm{H} 21 \mathrm{~A}$ & 0.655697 & 1.029354 & 0.118099 & $0.047 *$ \\
\hline $\mathrm{H} 21 \mathrm{~B}$ & 0.740498 & 1.077803 & 0.196807 & $0.047 *$ \\
\hline $\mathrm{H} 21 \mathrm{C}$ & 0.587317 & 1.097236 & 0.187709 & $0.047 *$ \\
\hline $\mathrm{C} 24$ & $0.6114(2)$ & $0.5353(3)$ & $0.04212(18)$ & $0.0380(6)$ \\
\hline $\mathrm{H} 24 \mathrm{~A}$ & 0.520791 & 0.526832 & 0.043617 & $0.046^{*}$ \\
\hline $\mathrm{H} 24 \mathrm{~B}$ & 0.648951 & 0.614629 & 0.040639 & $0.046^{*}$ \\
\hline $\mathrm{C} 20$ & $0.6404(3)$ & $0.9196(2)$ & $0.21713(18)$ & $0.0395(6)$ \\
\hline $\mathrm{H} 20 \mathrm{~A}$ & 0.637606 & 0.933851 & 0.275521 & $0.047 *$ \\
\hline $\mathrm{H} 20 \mathrm{~B}$ & 0.716539 & 0.867598 & 0.210232 & $0.047 *$ \\
\hline $\mathrm{C} 1$ & $0.0578(2)$ & $0.0933(3)$ & $0.25310(18)$ & 0.0419 (6) \\
\hline H1A & 0.040188 & 0.010736 & 0.272716 & $0.063 *$ \\
\hline H1B & 0.003875 & 0.108553 & 0.202659 & $0.063 *$ \\
\hline
\end{tabular}




\begin{tabular}{ccccc}
\hline H1C & 0.037901 & 0.154137 & 0.293353 & $0.063^{*}$ \\
C42 & $1.1996(3)$ & $0.5740(2)$ & $0.59215(17)$ & $0.0369(6)$ \\
H42A & 1.222543 & 0.510964 & 0.554145 & $0.055^{*}$ \\
H42B & 1.140730 & 0.538996 & 0.628521 & $0.055^{*}$ \\
H42C & 1.277975 & 0.603438 & 0.623535 & $0.055^{*}$ \\
C41 & $1.1337(2)$ & $0.6806(2)$ & $0.54599(16)$ & $0.0338(5)$ \\
H41A & 1.195875 & 0.719669 & 0.512559 & $0.041^{*}$ \\
H41B & 1.108049 & 0.742647 & 0.584756 & $0.041^{*}$ \\
H3 & $0.710(3)$ & $0.310(3)$ & $0.2704(17)$ & $0.024(7)^{*}$ \\
H1 & $0.053(3)$ & $0.439(3)$ & $0.3284(19)$ & $0.039(8)^{*}$ \\
\hline
\end{tabular}

Table S3 Atomic displacement parameters $\left(\AA^{2}\right)$ for (-)-CBD

\begin{tabular}{|c|c|c|c|c|c|c|}
\hline & $U^{11}$ & $U^{22}$ & $U^{33}$ & $U^{12}$ & $U^{13}$ & $U^{23}$ \\
\hline $\mathrm{O} 3$ & $0.0226(7)$ & $0.0219(7)$ & $0.0226(7)$ & $-0.0041(6)$ & $0.0081(6)$ & $0.0006(6)$ \\
\hline $\mathrm{O} 2$ & $0.0193(7)$ & $0.0212(7)$ & $0.0251(7)$ & $0.0035(6)$ & $0.0061(5)$ & $0.0077(6)$ \\
\hline $\mathrm{O} 1$ & $0.0183(7)$ & $0.0293(8)$ & $0.0272(8)$ & $0.0044(6)$ & $0.0045(6)$ & $0.0041(7)$ \\
\hline $\mathrm{O} 4$ & $0.0272(7)$ & $0.0211(7)$ & $0.0206(7)$ & $-0.0031(6)$ & $0.0074(6)$ & $0.0010(6)$ \\
\hline C32 & $0.0168(9)$ & $0.0192(9)$ & $0.0147(9)$ & $0.0021(7)$ & $-0.0002(7)$ & $0.0002(8)$ \\
\hline $\mathrm{C} 16$ & $0.0206(9)$ & $0.0184(9)$ & $0.0131(8)$ & $0.0014(7)$ & $0.0005(7)$ & -0.0008 \\
\hline $\mathrm{C} 36$ & $0.0177(9)$ & $0.0200(10)$ & $0.0219(10)$ & $0.0002(7)$ & $0.0003(7)$ & -0.0014 \\
\hline C33 & $0.0143(8)$ & 0.0209 (9) & $0.0163(9)$ & $0.0014(7)$ & $0.0003(7)$ & $0.0016(8)$ \\
\hline $\mathrm{C} 13$ & $0.0204(10)$ & $0.0203(9)$ & $0.0203(10)$ & $0.0027(8)$ & $-0.0045(7)$ & $-0.0016(8)$ \\
\hline $\mathrm{C} 31$ & $0.0203(10)$ & $0.0187(9)$ & $0.0137(8)$ & $0.0004(7)$ & $0.0016(7)$ & $-0.0001(8)$ \\
\hline $\mathrm{C} 30$ & $0.0203(10)$ & $0.0210(9)$ & $0.0181(9)$ & $0.0038(8)$ & $-0.0017(7)$ & $-0.0017(8)$ \\
\hline C37 & $0.0164(9)$ & $0.0222(10)$ & $0.0158(9)$ & $0.0014(7)$ & $0.0013(7)$ & $0.0028(8)$ \\
\hline $\mathrm{C} 15$ & $0.0198(9)$ & $0.0204(10)$ & $0.0163(9)$ & $-0.0034(7)$ & $0.0013(7)$ & $0.0005(8)$ \\
\hline $\mathrm{C} 17$ & $0.0250(10)$ & $0.0229(10)$ & $0.0227(10)$ & $-0.0013(8)$ & $-0.0038(8)$ & $0.0057(9)$ \\
\hline C34 & $0.0171(9)$ & $0.0266(11)$ & $0.0155(9)$ & $0.0026(7)$ & $0.0031(7)$ & $0.0033(8)$ \\
\hline C14 & $0.0233(10)$ & $0.0199(10)$ & $0.0156(9)$ & $-0.0015(8)$ & $-0.0049(8)$ & $-0.0002(8)$ \\
\hline $\mathrm{C} 4$ & $0.0234(10)$ & $0.0193(10)$ & $0.0236(10)$ & $-0.0011(8)$ & $0.0052(8)$ & $-0.0016(9)$ \\
\hline C35 & $0.0181(9)$ & $0.0256(10)$ & $0.0161(9)$ & $0.0047(8)$ & $-0.0011(7)$ & $-0.0021(8)$ \\
\hline $\mathrm{C} 25$ & $0.0219(10)$ & $0.0192(9)$ & $0.0142(9)$ & $-0.0001(7)$ & $0.0009(7)$ & $0.0005(8)$ \\
\hline $\mathrm{C} 12$ & $0.0194(9)$ & $0.0220(10)$ & $0.0149(8)$ & $-0.0001(7)$ & $-0.0009(7)$ & $-0.0032(8)$ \\
\hline
\end{tabular}




\begin{tabular}{|c|c|c|c|c|c|c|}
\hline $\mathrm{C} 11$ & $0.0197(9)$ & $0.0181(9)$ & $0.0132(8)$ & $-0.0011(7)$ & 0.0009 (7) & $-0.0012(8)$ \\
\hline $\mathrm{C} 10$ & $0.0191(9)$ & $0.0185(9)$ & $0.0170(9)$ & $-0.0008(7)$ & $0.0053(7)$ & $0.0004(8)$ \\
\hline $\mathrm{C} 28$ & $0.0230(10)$ & $0.0233(10)$ & $0.0210(10)$ & $0.0015(8)$ & $0.0046(8)$ & $-0.0011(8)$ \\
\hline $\mathrm{C} 26$ & $0.0284(11)$ & $0.0265(10)$ & $0.0145(9)$ & $-0.0006(8)$ & $0.0009(8)$ & $-0.0014(9)$ \\
\hline C38 & $0.0257(11)$ & $0.0318(12)$ & $0.0215(10)$ & $0.0053(9)$ & $0.0029(8)$ & $-0.0068(9)$ \\
\hline $\mathrm{C} 3$ & $0.0256(11)$ & $0.0210(10)$ & $0.0312(12)$ & $-0.0024(8)$ & $-0.0003(9)$ & $-0.0082(9)$ \\
\hline $\mathrm{C} 23$ & $0.0228(10)$ & $0.0295(11)$ & $0.0149(9)$ & $-0.0023(8)$ & $-0.0006(7)$ & $0.0015(9)$ \\
\hline $\mathrm{C} 18$ & $0.0324(12)$ & $0.0226(10)$ & $0.0247(11)$ & $-0.0038(9)$ & $-0.0047(9)$ & $0.0058(9)$ \\
\hline $\mathrm{C} 27$ & $0.0295(11)$ & $0.0300(11)$ & $0.0150(9)$ & $0.0003(9)$ & $0.0044(8)$ & $-0.0012(9)$ \\
\hline $\mathrm{C} 2$ & $0.0369(13)$ & $0.0266(12)$ & $0.0266(11)$ & $0.0017(9)$ & $-0.0054(9)$ & $\begin{array}{c}-0.0044 \\
(10)\end{array}$ \\
\hline C39 & $0.0359(12)$ & $0.0239(11)$ & $0.0206(10)$ & $0.0006(9)$ & $0.0011(9)$ & $-0.0067(9)$ \\
\hline C19 & $0.0301(11)$ & $0.0192(10)$ & $0.0224(10)$ & $-0.0017(8)$ & $0.0000(8)$ & $0.0023(8)$ \\
\hline C9 & $0.0248(10)$ & $0.0260(10)$ & $0.0149(9)$ & $-0.0013(8)$ & $0.0050(8)$ & $0.0027(8)$ \\
\hline $\mathrm{C} 5$ & $0.0385(13)$ & $0.0196(10)$ & $0.0375(13)$ & $-0.0032(9)$ & $0.0120(10)$ & $0.0014(10)$ \\
\hline $\mathrm{C} 40$ & $0.0299(11)$ & $0.0242(10)$ & $0.0212(10)$ & $0.0003(9)$ & $0.0014(8)$ & $-0.0022(9)$ \\
\hline $\mathrm{C} 7$ & $0.0332(12)$ & $0.0323(12)$ & $0.0191(10)$ & $0.0029(9)$ & $0.0094(9)$ & $0.0083(9)$ \\
\hline $\mathrm{C} 29$ & $0.0245(11)$ & $0.0425(13)$ & $0.0273(11)$ & $0.0029(10)$ & $0.0082(9)$ & $\begin{array}{c}-0.0026 \\
(11)\end{array}$ \\
\hline $\mathrm{C} 22$ & $0.0264(11)$ & $0.0353(13)$ & $0.0328(12)$ & $-0.0091(9)$ & $-0.0052(9)$ & $0.0063(10)$ \\
\hline $\mathrm{C} 6$ & $0.0444(14)$ & $0.0239(12)$ & $0.0344(12)$ & $0.0048(10)$ & $0.0092(10)$ & $0.0092(10)$ \\
\hline $\mathrm{C} 8$ & $0.0463(15)$ & $0.0468(15)$ & $0.0230(12)$ & $0.0114(12)$ & $0.0025(11)$ & $0.0150(11)$ \\
\hline $\mathrm{C} 21$ & $0.0399(13)$ & $0.0248(11)$ & $0.0303(12)$ & $\begin{array}{c}-0.0070 \\
(10)\end{array}$ & $0.0069(10)$ & $\begin{array}{c}-0.0004 \\
(10)\end{array}$ \\
\hline $\mathrm{C} 24$ & $0.0240(12)$ & $0.0386(13)$ & $0.0518(16)$ & $0.0030(10)$ & $0.0054(11)$ & $\begin{array}{c}-0.0007 \\
(12)\end{array}$ \\
\hline $\mathrm{C} 20$ & $0.0400(14)$ & $0.0292(13)$ & $0.0466(15)$ & $\begin{array}{c}-0.0111 \\
(11)\end{array}$ & $\begin{array}{c}-0.0096 \\
(11)\end{array}$ & $0.0102(12)$ \\
\hline $\mathrm{C} 1$ & $0.0275(12)$ & $0.0502(16)$ & $0.0473(15)$ & $\begin{array}{c}-0.0072 \\
(11)\end{array}$ & $\begin{array}{c}-0.0002 \\
(11)\end{array}$ & $\begin{array}{c}-0.0164 \\
(14)\end{array}$ \\
\hline $\mathrm{C} 42$ & $0.0346(13)$ & $0.0366(13)$ & $0.0376(14)$ & $\begin{array}{c}-0.0006 \\
(10)\end{array}$ & $\begin{array}{c}-0.0067 \\
(10)\end{array}$ & $\begin{array}{c}-0.0009 \\
(11)\end{array}$ \\
\hline C41 & $0.0382(13)$ & $0.0291(12)$ & $0.0322(13)$ & $\begin{array}{c}-0.0034 \\
(10)\end{array}$ & $\begin{array}{c}-0.0067 \\
(10)\end{array}$ & $\begin{array}{c}-0.0012 \\
(10)\end{array}$ \\
\hline
\end{tabular}

Figure S81. X-Ray Structure of (-)-CBD 


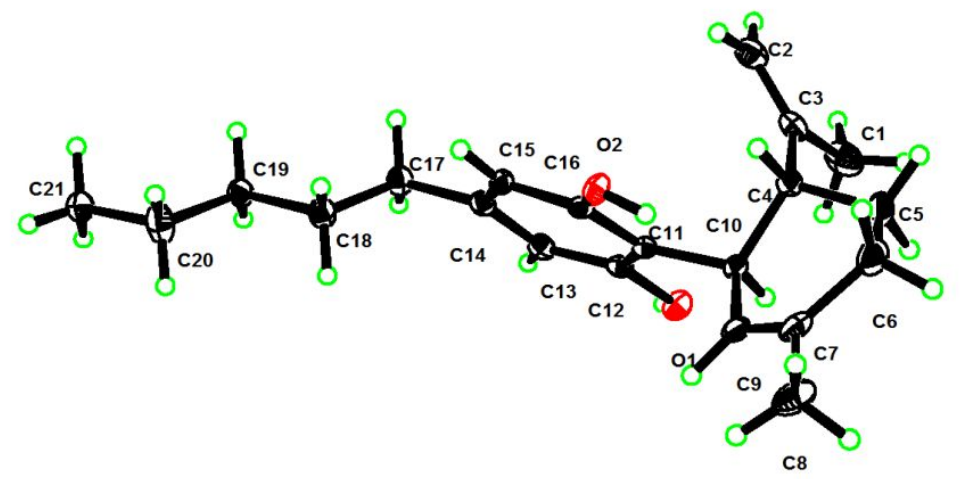

Thermals ellipsoids are shown with 50\% probability. 